\title{
XIX Dni Otolaryngologii Dziecięcej, Jachranka, 7-9 maja 2015 r.
}

\section{8 maja 2015 r.}

\section{SALA A}

\section{I.1 - The utility of FEES (Fiberoptic Endoscopic Evaluation of Swallowing) in the breastfeeding infant}

\section{J. Schroeder}

Ann and Robert H. Lurie, Children's Hospital of Chicago, Chicago, USA

\section{I.2 - Management of vocal cord paralysis in children}

\section{Bailey}

Great Ormond Street Hospital for Children, London, UK

\section{I.3 Możliwości i ograniczenia chirurgii endoskopowej krtani}

\section{Zawadzka-Głos}

Klinika Otolaryngologii Dziecięcej Uniwersytety Medycznego $w$ Warszawie

We współczesnych czasach nastąpił zdecydowany rozwój technik endoskopowych w chirurgii. Endoskopia krtani była i jest podstawowym narzędziem diagnostycznym w rozpoznawaniu chorób krtani. Jest złotym standardem postępowania u pacjentów, u których występują objawy związane z patologią krtani, takie jak: stridor krtaniowy, chrypka, bezgłos, zaburzenia połykania pod postacią zachłystywania się pokarmem. Endoskopię krtani możemy przeprowadzić przy użyciu giętkich fiberoskopów lub przy użyciu sztywnych optyk o różnym kącie patrzenia. Do diagnostyki endoskopowej krtani przyzwyczailiśmy się od wielu lat i uznajemy te metody za naturalne. Możliwości endoskopii jednak zaczynają odgrywać znaczącą rolę w leczeniu inwazyjnym chorób krtani. Odstępuje się w niektórych przypadkach od obciążających zabiegów metodą chirurgii otwartej na rzecz chirurgii endoskopowej. Przykładem mogą być niektóre formy rozszczepów tylnych krtani lub zabiegi polegające na odwiedzeniu struny głosowej lub chordectomia z/lub bez arytenoidectomii w przypadkach obustronnego porażenia strun głosowych. Leczeniu endoskopowemu możemy poddać pacjenta $\mathrm{z}$ torbielą krtani, zwężeniem okolicy podgłośniowej I i II stopnia w skali Cottona, ziarninowaniem w tchawicy i krtani. Endoskopowo leczy się niektóre formy laryngomalacji u dzieci. Istnieją możliwości wykonania tracheotomii przezskórnej metodą Fantoniego, gdzie kontrola endoskopowa jest niezbędna dla prawidłowego wyznaczenia miejsca rozpoczęcia procedury. Techniki endoskopowe wiążą się z mniejszą traumatyzacją tkanek, skracają czas hospitalizacji, ograniczają krwawienie śródoperacyjne. Są dobrze tolerowane przez pacjenta, a użycie torów wizyjnych, powiększenia obrazu daje komfort dla operatora. Oczywiście chirurgia endoskopowa nie może być stosowana bez ograniczeń. Istnieja patologie krtani, które nie powinny być leczone w ten sposób i wymagają zastosowania chirurgii otwartej. Dotyczy to zwężeń krtani i tchawicy III i IV stopnia według Cottona, wieloodłamowych złamań rusztowania chrzęstnego krtani i tchawicy, dużych zmian nowotworowych. Wybór metody leczenia powinien być dokładnie rozważony, ponieważ często pierwszy zabieg decyduje o dalszym przebiegu leczenia. Chirurgię endoskopową stosuje się również jako uzupełniającą po leczeniu metodami otwartymi na przykład w celu usuwania tkanek ziarninowych lub poszerzania wtórnych zmian o charakterze zwężeń pooperacyjnych.

Słowa kluczowe: endoskopia • krtań • dzieci

\section{I.4 • Jednoetapowa rekonstrukcja krtani i tchawicy}

\section{Bielecki}

Oddział Laryngologii, Górnośląskie Centrum Zdrowia Dziecka, Śląski Uniwersytet Medyczny w Katowicach

Zwężenia krtani i tchawicy u dzieci najczęściej występują w okolicy podgłośniowej. Zwężenia wrodzone są często spowodowane deformacją chrząstki pierścieniowatej, wiotkością krtani i tchawicy oraz zaburzeniami neurogennymi. Zwężenia nabyte są najczęściej skutkiem urazów pointubacyjnych. Operacje zwężeń krtani i tchawicy są wykonywane metodą dwu- lub jednoetapową. W operacji dwuetapowej, w pierwszym etapie wykonywana jest 
rekonstrukcji krtani, a w drugim etapie usuwana jest rurka tracheostomijna. W metodzie jednoetapowej przeprowadza się operację poszerzającą zwężony odcinek drogi oddechowej oraz jednoczasowo wykonuje dekaniulację. Ta metoda po raz pierwszy została zastosowana w 1991 roku i zyskuje coraz więcej zwolenników. Autor przedstawia własne doświadczenia w zastosowaniu tej metody leczenia oraz aktualne opinie innych chirurgów na ten temat.

\section{I.5 Zaburzenia oddychania u noworodków}

\section{J. Szydłowski}

Klinika Otolaryngologii Dziecięcej Katedry Otolaryngologii i Onkologii Laryngologicznej Uniwersytetu Medycznego w Poznaniu

Wstęp: Zaburzenia oddychania u noworodków i niemowląt są najczęstszą przyczyną bezpośredniego zagrożenia życia $\mathrm{w}$ tej grupie wiekowej. Brak prawidłowej wentylacji wyzwala kaskadę zaburzeń metabolicznych, które wobec ograniczonych możliwości kompensacyjnych małego dziecka prowadzą do częściowej lub całkowitej niewydolności oddechowej. W ogromnej większości przypadków resuscytacja krążeniowo-oddechowa noworodków ma charakter przewidywalny. W kręgu zainteresowania laryngologów znajdują się jednak przypadki powiązane z zaburzeniami drożności dróg oddechowych od nozdrzy przednich aż do poziomu tchawicy, w których standardowe procedury podejmowane przez neonatologów i pediatrów pozostają często niewystarczające.

Materiał i metody: Praca stanowi systematyczny przegląd nieprawidłowości anatomicznych i czynnościowych zlokalizowanych w obrębie dróg oddechowych oraz zaburzeń obejmujących inne narządy pośrednio wpływających na czynność układu oddechowego. W oparciu o zgromadzony materiał kliniczny i doświadczenia Ośrodka autor przedstawia sposoby postępowania obejmujące szeroki zakres działań, począwszy od śródporodowych interwencji chirurgicznych aż po zabiegi rekonstrukcyjne wykonywane zarówno minimalnie inwazyjnymi technikami endoskopowymi, jak i metodami chirurgii otwartej.

Wyniki i wnioski: Wyniki leczenia poszczególnych jednostek chorobowych w dużej mierze zależą od fenotypowego obrazu danej patologii oraz często spotykanych w wadach wrodzonych współistniejących nieprawidłowości obejmujących inne układy i narządy. W przypadku wad wrodzonych przebiegających $\mathrm{z}$ całkowitą niedrożnością układu oddechowego, kluczowego znaczenia nabiera wnikliwa obrazowa diagnostyka perinatologiczna, umożliwiająca odpowiednie przygotowanie i zaplanowanie wczesnej interwencji chirurgicznej bezpośrednio okołoporodowo lub w procedurze EXIT. Podczas zabiegów odtwarzających prawidłowy pasaż powietrza w drogach oddechowych, szczególnie w operacjach naprawczych prowadzonych w obrębie krtani i tchawicy, niezbędna jest dobra współpraca $z$ doświadczonym zespołem anestezjologicznym a niejednokrotnie także torakokardiochirurgicznym.
Słowa kluczowe: noworodki • wady wrodzone • zaburzenia oddychania

\section{III.1 - Wyniki leczenia endoskopowego włókniaka młodzieńczego}

\section{JNA endoscopical removal - treatment results}

\section{W. Szyfter, T. Kopeć}

Klinika Otolaryngologii i Onkologii Laryngologicznej Uniwersytetu Medycznego w Poznaniu

Wstęp: Techniki endoskopowe są obecnie metodą z wyboru w leczeniu włókniaka młodzieńczego bez penetracji wewnątrzczaszkowej. Celem pracy było przedstawienie wyników leczenia chorych poddanych leczeniu endoskopowemu.

Materiał i metody: W latach 2000-2015 w Klinice Laryngologii i Onkologii Laryngologicznej w Poznaniu leczono 33 chorych płci męskiej z rozpoznaniem włókniaka młodzieńczego. Przedmiotem analizy jest grupa 13 chorych, u których zabieg wykonano endoskopowo. Wiek chorych wahał się od 11 do19 lat, średnia 14,6. U 12 na 13 pacjentów $\mathrm{w}$ okresie przedoperacyjnym wykonano angiografię i embolizację naczyń odżywiających guz. Jeden chory leczony był z powodu wznowy. Każdorazowo podczas zabiegu stosowano nawigację elektromagnetyczną. Zabieg dokonano $\mathrm{z}$ dojścia przez jedno nozdrze przy wykorzystaniu techniki czterech rąk.

Wyniki: Całkowite usunięcie guza możliwe było we wszystkich przypadkach. Utrata krwi podczas zabiegu wyniosła od $100 \mathrm{ml}$ do $1200 \mathrm{ml}$, średnio $300 \mathrm{ml}$. Czas hospitalizacji pooperacyjnej wahał się od 3 do 5 dni, średnio 3,3 dnia. Czas obserwacji wyniósł od sześciu miesięcy do 8 lat, średnio 3,8 roku.

Podsumowanie: Usunięcie włókniaka młodzieńczego w przypadku guzów kwalifikujących się do dostępu endoskopowego jest bezpieczne dla pacjenta, zwłaszcza przy zastosowaniu nawigacji. Zabieg operacyjny dzięki zastosowaniu embolizacji związany jest $\mathrm{z}$ małą utratą krwi, technika endoskopowa przyczynia się natomiast do krótszego czasu hospitalizacji po zabiegu i lepszych efektów kosmetycznych.

\section{III.2 - Lymphatic malformations}

\section{R. Nicollas}

Pediatric Otolaryngology Head and Neck Surgery, La Timone Children's Hospital, Marseille, France 
III.3 - Wiodąca rola chirurga w leczeniu wrodzonych anomalii naczyniowych tkanek miękkich głowy i szyi

\section{Wyrzykowski, B. Chrzanowska, P. Czauderna}

Klinika Chirurgii i Urologii Dzieci i Młodzieży Uniwersytetu Medycznego w Gdańsku

Wstęp: Wrodzone anomalie naczyniowe to najczęściej występujące zmiany patologiczne powłok. W 60-75\% przypadków dotyczą one głowy i szyi, często stanowiąc problem czynnościowy i/lub estetyczny i z tego powodu wymagając leczenia. Podstawą do podjęcia decyzji o leczeniu jest postawienie rozpoznania w oparciu o obowiązującą klasyfikację biologiczną. Leczenie wrodzonych anomalii naczyniowych ma na celu poprawę komfortu życia pacjenta. Wybór metody leczenia zależy od typu zmiany naczyniowej, ale również jej wielkości, lokalizacji, wieku pacjenta, rodzaju powodowanych dolegliwości itd. Najlepsze wyniki daje łączenie różnych metod leczenia, takich jak laseroterapia, skleroterapia i wycięcie chirurgiczne.

Materiał i metody: Ponad $10 \%$ osób w populacji jest „naznaczonych” wrodzoną anomalią naczyniową, wśród których wyróżnia się zmiany proliferujące (naczyniaki i inne guzy naczyniowe) oraz zaburzenia architektoniki naczyń (malformacje). Zdecydowanie najczęściej spotykane zmiany to naczyniaki wczesnodziecięce, których historia biologiczna podzielona jest na fazy $\mathrm{z}$ nieuniknioną ostatecznie inwolucją. Pomimo spontanicznego zaniku, około 15-20\% $\mathrm{z}$ nich wymaga leczenia, ponieważ zaburzają rozwój ważnych funkcji życiowych lub ulegają powikłaniom. Wprowadzenie od 2008 roku terapii systemowej Propranololem zmieniło dotychczasowe zasady postępowania, nie eliminując jednak potrzeby leczenia chirurgicznego w wielu przypadkach.

Malformacje naczyniowe nie zanikają, a wręcz ulegają stopniowej progresji, wymagając leczenia na jakimś etapie rozwoju. Leczenie to laseroterapia, skleroterapia/embolizacja i leczenie operacyjne. W większości zmian powodujących nadmiar tkanek, zniszczenie skóry, inwazję głębiej położonych przedziałów, w tym mięśni, podstawową metodą leczenia pozostaje wycięcie chirurgiczne. Nawet resekcje częściowe zazwyczaj w znaczący sposób zmieniają jakość życia pacjenta.

Wyniki: Zaprezentowane zostanie postępowanie na konkretnych wybranych przykładach klinicznych.

Wnioski: 1. Wrodzone anomalie naczyniowe występują najczęściej w obrębie głowy i szyi, stanowiąc codzienne wyzwanie dla specjalistów laryngologii. 2. Podstawowym warunkiem przed podjęciem leczenia jest umiejętność postawienia prawidłowego rozpoznania w oparciu o klasyfikację biologiczną ISSVA. 3. Leczenie wrodzonych wad naczyniowych powłok wymaga zaangażowania lekarzy wielu specjalności. 4. Leczenie chirurgiczne pozostaje najważniejszą z metod, która jest uzupełniana poprzez procedury laserowe i interwencje radiologiczne.
III.4 - Dobrze unaczynione guzy przestrzeni przygardłowej oraz przestrzeni naczyń szyjnych u dzieci - spojrzenie radiologa

\section{A. Trojanowska}

Zakład Radiologii i Medycyny Nuklearnej, Samodzielny Publiczny Szpital Kliniczny Nr 4 w Lublinie

\section{V.1 • Risk management in paediatric airway surgery}

M. Bailey

Great Ormond Street Hospital for Children, London, UK

\section{V.2 - How can fluid dynamics and numerical modeling help physicians in the management of pediatric airway pathology}

\section{R. Nicollas}

Pediatric Otolaryngology Head and Neck Surgery, La Timone Children's Hospital, Marseille, France

\section{V.3 - Laryngomalacia and its variants: contemporary evaluation and management}

\section{Thompson}

Ann and Robert H. Lurie, Children's Hospital of Chicago, Chicago, USA

\section{V.4 Open versus endoscopic approach in the management of laryngo-tracheal disorders in pediatrics}

\section{R. Nicollas}

Pediatric Otolaryngology Head and Neck Surgery, La Timone Children's Hospital, Marseille, France

\section{V.5 - Airway evaluation and management in PRS: Pierre Robin Sequence}

\section{J. C. Rastatter}

Ann and Robert H. Lurie, Children's Hospital of Chicago, Chicago, USA 


\section{VII.6 • Sesja OLYMPUS • Nowoczesne techniki chirurgiczne $w$ tonsilektomii i adenotomii}

\section{Vicini}

Ospedale Morgagni - Pierantoni, Forli, Włochy

\section{IX.1 • HPV - fakty i mity}

\section{W. Golusiński}

Klinika Chirurgii Głowy, Szyi i Onkologii Laryngologicznej Uniwersytetu Medycznego w Poznaniu, Wielkopolskie Centrum Onkologii

\section{IX.2 • Kliniczna efektywność szczepionki HPV w profilaktyce zakażeń wirusem brodawczaka ludzkiego}

\section{E. Bernatowska}

Klinika Immunologii, Instytut „Pomnik - Centrum Zdrowia Dziecka" w Warszawie

Profesor Harald zur Hausen wykazał, że raka szyjki macicy wywołuje wirus brodawczaka ludzkiego (HPV), za swoje odkrycie w 2008 r. otrzymał Nagrodę Nobla w dziedzinie fizjologii i medycyny. Wysokie ryzyko onkologiczne wykazują następujące typy wirusa: 16, 18, 31, 33, 41, 45, 51, $52,56,58$, natomiast wirusy 6 i 11 cechuje niskie ryzyko onkologiczne. Obecnie dostępna szczepionka 4-walentna (typ wirusa 16, 18, 6, 11) zalecana jest dziewczynkom od 9 r.ż. i chłopcom od 9 do 26 roku życia, zapobiega występowaniu zmian przednowotworowych narządów płciowych (szyjki macicy, sromu i pochwy), zmian przednowotworowych odbytnicy, raka szyjki macicy oraz raka odbytnicy, zapobiega również brodawkom narządów płciowych (kłykcinom kończystym), związanym przyczynowo z zakażeniem określonymi typami wirusa brodawczaka ludzkiego. W przypadku nowotworów głowy i szyi nie prowadzi się badań przesiewowych, tak jak w przypadku raka szyjki macicy, gdzie wysoka skuteczność przeciwnowotworowa szczepień ochronnych jest już dawno wykazana. $Z$ tego powodu efektywność kliniczna szczepionek, zawierających antygeny wirusa typu 6 i $11 \mathrm{w}$ profilaktyce HPV-zależnego nowotworu jamy ustnej i gardła jest obecnie trudna do oszacowania. Nieliczne, pojedyncze doniesienia są jednak obiecujące. Czteroletnie obserwacje 5840 młodych kobiet zaszczepionych szczepionką HPV-2 walentną (typ 16 i 18) wykazały mniejszą częstość zakażeń HPV w obrębie jamy ustnej w porównaniu z grupą nie szczepioną, co potencjalnie zmniejsza ryzyko wystąpienia raka jamy ustnej i gardła wywołanych przez wirus typu 16 (Rolando Herrero, PLOS One, 2013; 8: 7).Więcej jest prac kazuistycznych, dotyczących rzadkich, nawrotowych brodawczaków krtani, które potencjalnie mogą przejść w zmiany nowotworowe. Zastosowanie 3 dawek szczepionki 4-walentnej (16, $18,6,11)$ redukuje istotnie liczbę nawrotów lub powoduje całkowite ustąpienie brodawczaków. Zaawansowane są prace nad kilkoma szczepionkami terapeutycznymi w leczeniu uporczywych brodawczaków głowy i szyi zawierającymi antygen wirusów 6 i 11. Podejmując strategiczne decyzje dotyczące wyboru szczepionki w realizacji programów profilaktycznych, należy zdać sobie sprawę, że zakażenie wirusem HPV typu 6,11, o niskim potencjale onkogennym występujące znacznie częściej niż wysoko onkogennym wirusem HPV typu 16, 18, dlatego szeroko stosowana $\mathrm{w}$ wielu krajach profilaktyka zakażeń HPV typem 6 i 11, jej skuteczność w zapobieganiu 15\% zmian przednowotworowych szyjki macicy oraz odbytnicy wywołanych przez te wirusy przekłada się także na spadek zakażeń w obrębie szyi i głowy oraz zmniejsza potencjalne ryzyko rozwoju HPV-zależnego nowotworu jamy ustnej i gardła. Należy jednocześnie podkreślić, że zmniejszenie częstości raka szyjki macicy w przyszłości może spowodować wzrost częstości występowania HPV-zależnego płaskonabłonkowego raka głowy i szyi.

\section{IX.3 - Leczenie brodawczaków krtani przy użyciu Cidofoviru}

\section{Bielecki}

Oddział Laryngologii, Górnośląskie Centrum Zdrowia Dziecka Ślaskiego Uniwersytetu Medycznego w Katowicach

Nawracające brodawczaki krtani są wywołane przez wirus brodawczaka ludzkiego HPV, w większości przypadków typu 6 i 11. Choroba w 70-80\% przypadków pojawia się przed piątym rokiem życia. Do tej pory nie znaleziono skutecznej metody leczenia brodawczaków krtani. Jedną $\mathrm{z}$ metod leczenia wspomagającego jest zastosowanie śródtkankowych iniekcji cidofoviru. Jest to lek przeciwwirusowy, który hamuje replikację cząsteczek DNA wirusa i ma zastosowanie głównie w leczeniu zakażeń siatkówki wirusem CMV. Po raz pierwszy zastosowanie cidofoviru w leczeniu brodawczaków krtani u dzieci opisał Pransky w 1999 roku. Od tej pory ta metoda leczenia jest stosowana w wielu ośrodkach na całym świecie. Autor przedstawia własne, 10-letnie obserwacje oraz aktualny stan wiedzy na temat zastosowania tej metody leczenia.

\section{Sesja XI • 16:30-18:00 • Chirurgia endoskopowa zatok (FESS) - pokaz}

\section{J. Mierzwiński, K. Dalke}




\section{SALA B}

\section{II.1 - Diagnostyka niedosłuchu u dzieci}

\section{Diagnosis of hearing loss in children}

\section{J. Kuczkowski}

Klinika Otolaryngologii Uniwersytetu Medycznego w Gdańsku

Wstęp: Niedosłuch jest częstym objawem chorób ucha u dzieci. W okresie noworodkowym i niemowlęcym dominują niedosłuchy o charakterze odbiorczym, a w okresie wczesnodziecięcym i szkolnym niedosłuchy przewodzeniowe wywołane chorobami ucha zewnętrznego i środkowego. Trudności diagnostyczne wynikają z uwarunkowań genetycznych wad słuchu, zaburzeń rozwojowych w obrębie ucha, a przede wszystkim z częstego braku współpracy dzieci w trakcie trudnych i długotrwałych badań. Celem pracy jest przedstawienie trudności w rozpoznawaniu niedosłuchów u dzieci z różnymi schorzeniami w obrębie ucha zewnętrznego, środkowego i wewnętrznego.

Materiał i metoda: Przedstawiono analizę wyników badań psychofizycznych oraz obiektywnych słuchu u dzieci przeprowadzonych w Poradni Audiologicznej Kliniki Otolaryngologii UCK GUMed. Szczególną uwagę zwrócono na wyniki badań u dzieci z wrodzonym niedosłuchem lub z wadami rozwojowymi ucha (zespół Downa, Aspergera, zwężenia psz, unieruchomienia kosteczek słuchowych). Omówiono metody badawcze ze szczególnym uwzględnieniem warunków niezbędnych do przeprowadzenia badania słuchu. Przedstawiono analizę badań oraz technikę badania u dzieci $\mathrm{z}$ utrudnionym kontaktem oraz słabo współpracujących.

Wyniki badań i omówienie: Wykazano, że u dzieci w okresie noworodkowym, niemowlęcym oraz wczesnego dzieciństwa skuteczną metodą badania niedosłuchu jest badanie ASSR, ABR, OAE oraz audiometria impedancyjna. Wskazano na konieczność wykonywania kilkukrotnych badań tympanometrycznych u dzieci z wysiękowym zapaleniem ucha środkowego. W wybranych przypadkach u dzieci z zaburzeniami rozwojowymi, a w szczególności autyzmem, istnieje konieczność wykonania badania ABR w śnie farmakologicznym. Szczególny problem istnieje w przypadku badań dzieci z zespołem autystycznym, zespołem Downa oraz z wadami rozwojowymi w obrębie ucha zewnętrznego i środkowego. Wskazano na konieczność wykonywania kolejnych badań ABR, otoemisji i badań audiometrycznych u dzieci starszych, u których stwierdzono cechy uszkodzenia ucha wewnętrznego.

Wnioski: Diagnostyka niedosłuchu u dzieci jest bardzo trudna. Powinna ona uwzględniać: okres rozwojowy dziecka, głębokość niedosłuchu, rodzaj niedosłuchu oraz obecność wad rozwojowych w zakresie ucha zewnętrznego i środkowego. Najlepszym narzędziem diagnostycznym $\mathrm{w}$ niedosłuchu u dzieci jest badanie otoemisji, ABR, ASSR oraz audiometria impedancyjna. Przed wykonaniem badania słuchu u dziecka warunkiem nieodzownym jest dokładna ocena ucha zewnętrznego.

\section{II.2 • Diagnostyka zawrotów głowy i zaburzeń równowagi}

\section{W. Narożny}

Katedra i Klinika Otolaryngologii Uniwersytetu Medycznego w Gdańsku

Część wstępną pracy poświęcono informacjom dotyczącym embriogenezy ucha wewnętrznego oraz wczesnych etapów dojrzewania układu nerwowego człowieka.

Metody diagnostyki zawrotów głowy i zaburzeń równowagi u dzieci powinny być zawsze dostosowane do ich wieku. Grupa otolaryngologów i neurologów polskich skupiona w VERTIGOFORUM określiła w 2011 r. dolną granicę wieku dzieci, przy której najwcześniej można wykonywać najważniejsze badania otoneurologiczne. Według tych ustaleń:

- próby obrotowe (matka siedząc na krześle obrotowym trzyma badane dziecko) - 3 r.ż.,

- próby kaloryczne - 5 r.ż.,

- ENG, VNG - 5 r.ż.,

- badania audiologiczne:

- testy obiektywne - w każdym wieku,

- badania progowe i nadprogowe - 7 r.ż.

Główne elementy diagnostyki zawrotów głowy i zaburzeń równowagi u dzieci to:

1. Wywiad: pre-, peri-, postnatalny oraz dotyczący dolegliwości bieżących.

2. Badanie otorynolaryngologiczne.

3. Badanie otoneurologiczne (neuroprzedsionkowe):

- próby koordynacyjne,

- próby posturalne,

- ENG, VNG, EEG,

- posturografia,

- ocena oczopląsu samoistnego.

4. Badanie okulistyczne.

5. Badania audiologiczne (obiektywne i subiektywne).

6. Badania obrazowe - CT, MRI.

7. Badania laboratoryjne.

Specyfika diagnostyki zawrotów głowy i zaburzeń równowagi u dzieci polega na:

1. Braku wiarygodnego wywiadu od chorego dziecka.

2. Różnicach w obrazie klinicznym zawrotów głowy między poszczególnymi dziecięcymi grupami wiekowymi.

3. Obecności ograniczeń wiekowych dla stosowanych u dzieci metod diagnostycznych zawrotów głowy.

4. Wymogu wieloletniej obserwacji dziecka z zawrotami wynikającego $\mathrm{z}$ ewolucji obrazu klinicznego tych dolegliwości u tych chorych. 


\section{II.3 - Ocena ośrodkowych procesów słyszenia u dzieci}

\section{G. Mielnik-Niedzielska}

Klinika Otolaryngologii Dziecięcej, Foniatrii i Audiologii w Lublinie

Centralne zaburzenia przetwarzania słuchowego (Central Auditory Processing Disorders, CAPD) są zaburzeniami słuchu o lokalizacji ośrodkowej. Opisywane są jako niemożność pełnego wykorzystania słyszanego sygnału akustycznego przy prawidłowym jego odbiorze w strukturach obwodowych narządu słuchu. Ośrodkowe zaburzenia przetwarzania słuchowego mogą się objawiać jako zaburzenia analizy czasowej sygnału dźwiękowego, różnicowania i rozpoznawania wzorców dźwiękowych, lokalizacji i lateralizacji dźwięku oraz utrudnionego rozumienia sygnału w obecności sygnału zagłuszającego. Zaburzenia percepcji słuchowej utrudniają dostęp do informacji dźwiękowych dziecka, co utrudnia rozwój mowy i języka, a w konsekwencji wpływa na postępy w nauce. Diagnoza może być poparta testami elektroakustycznymi, neuroobrazowaniem oraz testami behawioralnymi. Do pomiarów elektroakustycznych zaliczamy rejestracje potencjałów wywołanych z pnia mózgu, rejestracje potencjałów średniolatencyjnych, falę niezgodności oraz potencjały poznawcze. Nadal brakuje szeroko zaakceptowanego zestawu testów diagnostycznych. Ponieważ stosowane badania powinny odzwierciedlać różnorodne procesy przetwarzania, wydaje się słuszne, by zastosowane testy psychoakustyczne obejmowały: testy dyskryminacji słuchowej (dyskryminacji częstotliwości i intensywności), testy przetwarzania czasowego - testy sekwencji tonów o różnej długości i wysokości, testy dychotyczne oceniające integrację i separację obuuszną i lateralizację półkulową, testy mowy utrudnionej i testy interakcji obuusznej. Do baterii diagnostycznej należy włączyć badanie psychologiczne $\mathrm{z}$ oceną poziomu inteligencji oraz badanie pod kątem zaburzeń zachowania i emocjonalnych. Wiele osób z problemami centralnego przetwarzania słuchowego ma choroby towarzyszące, jak np. zaburzenia uwagi, nadpobudliwość, opóźnienie rozwoju mowy czy niedosłuch, które mogą wpływać na wyniki badan behawioralnych i elektrofizjologicznych, dlatego dokładna diagnoza jest niezbędna, by można było zaordynować właściwą terapię. Zaburzenia przetwarzania informacji słuchowej, które nie zostały poddane terapii, prowadzą do zaburzenia procesu komunikatywnego dziecka, głównie poprzez trudności w rozumieniu mowy. Mogą być przyczyną trudności w czytaniu i pisaniu, co utrudnia edukację szkolną.

\section{IV.1 • Nowotwory lite głowy i szyi u dzieci}

\section{E. Hassmann-Poznańska}

Klinika Otolaryngologii Dziecięcej w Białymstoku

Mięsaki tkanek miękkich stanowią jedynie 7\% wszystkich guzów złośliwych u dzieci, jednakże połowa z nich lokalizuje się w obrębie głowy i szyi, stąd też znajomość symptomatologii i metod leczenia jest bardzo ważna dla otolaryngologów dziecięcych. Mięsaki są heterogenną grupą nowotworów pochodzenia mezenchymalnego, charakteryzującą się specyficznymi zaburzeniami chromosomalnymi o typie translokacji. Mięsak prążkowanokomórkowy (RMS) stanowi około połowę z nich u dzieci. Pozostałe są rzadkie (mięsak maziówkowy, włókniakomięsak, złośliwy nowotwór osłonek nerwów obwodowych (MPNST), prymitywny guz neuroektodermalny, obwodowy niedojrzały guz neuroektodermalny, PNET). Częstsze występowanie niektórych mięsaków obserwuje się w zespole Li-Fraumeni, nerwiakowłókniakowatości typu I, zespole Beckwitha-Wiedemanna.

RMS w obrębie głowy i szyi występuje głównie u młodszych dzieci i najczęściej jest to postać histologiczna zarodkowa (ERMS), rokująca lepiej. U nastolatków częściej występuje postać pęcherzykowa (ARMS), wiążąca się z gorszym rokowaniem. W obrębie głowy i szyi wyróżnia się lokalizację okołooponową (jamy nosa, część nosowa gardła, zatoki przynosowe, dół skrzydłowo-podniebienny i podskroniowy, ucho środkowe) i nieokołooponową. Lokalizacja okołooponowa cechuje się większą częstością wznów miejscowych, destrukcją podstawy czaszki i naciekaniem opon mózgowo-rdzeniowych.

Kliniczne objawy przy guzach zlokalizowanych w obrębie głowy i szyi są niecharakterystyczne, zwykle związane z pojawieniem się niebolesnego guza. Przy lokalizacji w obrębie górnych dróg oddechowych dominują zaburzenia oddychania, szczególnie w nocy. Przy lokalizacji w uchu środkowym obserwuje się wycieki krwiste z ucha i obecność polipowatych zmian w przewodzie słuchowym zewnętrznym. W lokalizacji okołooponowej występują porażenia nerwów czaszkowych. Przerzuty do węzłów chłonnych są rzadkie - 7\%. Przerzuty odległe najczęściej lokalizują się w płucach, szpiku, wątrobie i mózgu.

Zarówno diagnostyka, jak i leczenie powinny być prowadzone w ścisłej współpracy i pod kierunkiem onkologów dziecięcych. Leczenie chirurgiczne, jeżeli nie powoduje znacznej destrukcji i zaburzeń czynnościowych, jest wskazane, ponieważ w sposób istotny wpływa na wynik leczenia i umożliwia uniknięcie radioterapii. Niestety większość guzów z lokalizacją okołooponową nie kwalifikuje się do radykalnego leczenia chirurgicznego w chwili rozpoznania. Leczenie zwykle obejmuje chemioterapię, radioterapię i leczenie chirurgiczne, jeżeli tylko jest ono możliwe. Wyniki leczenia są obecnie znacznie lepsze niż przed wprowadzeniem chemioterapii - $72 \%$ przeżyć 5-letnich przy lokalizacji okołooponowej. 


\section{IV.2 - Badanie histopatologiczne $\mathrm{w}$ diagnostyce laryngologicznej}

\section{J. Małdyk}

Zakład Patomorfologii Warszawskiego Uniwersytety Medycznego $w$ Warszawie

Badanie histopatologiczne w diagnostyce laryngologicznej, podobnie jak w innych specjalnościach, służy potwierdzeniu podejrzeń klinicznych i ustaleniu rozpoznania.

Wynik badania może być przekazany w ciągu 2-3 dni. Często jednak czas oczekiwania na diagnozę wydłuża się. Przyczyny mogą być różne. Niektóre związane są z małą liczbą specjalistów i zbyt dużą liczbą badań. Bywa, że badanie jest niejednoznaczne, a diagnoza wymaga wykonania tzw. barwień dodatkowych. Wśród przyczyn opóźniających diagnozę są też skąpe informacje kliniczne, materiał niereprezentatywny, rozfragmentowany lub bardzo mała jego ilość.

W materiale laryngologicznym pochodzącym od pacjentów pediatrycznych wyróżnia się zasadniczo 3 grupy zmian:

- zmiany nienowotworowe;

- nowotwory;

- zaburzenia wrodzone.

Wśród zmian nienowotworowych najczęstsze są zapalenia. W materiale $z$ przewodu słuchowego wymagają często różnicowania $\mathrm{z}$ histiocytozą $\mathrm{z}$ komórek Langerhansa. $\mathrm{Z}$ zatok i nosa są to przewlekłe zmiany zapalne błony śluzowej z tworzeniem polipów lub bez. Materiał z tonsilektomii to odczynowe przerosty migdałków z koniecznością wykluczenia promienicy.

Nowotwory widziane często jak formacje guzowate lub zmiany naciekowe wymagają zróżnicowania pomiędzy łagodnymi i złośliwymi proliferacjami.

Do najczęstszych łagodnych zmian występujących u dzieci w obrębie twarzoczaszki należą: naczyniaki i włókniaki. Złośliwe proliferacje w tej okolicy to: rhabdomyosarcoma (30-40\%), chłoniak Burkitta (16\%), rak nosogardła (30\%), esthesioneuroblastoma (5\%).

Zmiany guzowate występujące $\mathrm{u}$ dzieci, zwłaszcza małych, wymagają różnicowania $\mathrm{z}$ zaburzeniami rozwojowymi, takimi jak: cystis dermoidalis, nasal glioma, encephalocele. Często budzą duży niepokój kliniczny, a właściwe rozpoznanie pozwala na zastosowanie właściwej terapii.

\section{IV.3 • Epidemiologia i koordynacja leczenia nowotworów głowy i szyi u dzieci}

\section{Malinowska}

MD Clinic $w$ Warszawie

Diagnostyka różnicowa guzów w obrębie głowy i szyi obejmuje wiele łagodnych zmian oraz nowotworów złośliwych.
Nowotwory złośliwe głowy i szyi stanowią około 5\% wszystkich chorób nowotworowych u dzieci. Mogą mieć charakter pierwotnego guza lub przerzutów do szyjnych węzłów chłonnych. Najczęściej występującymi nowotworami w obrębie głowy i szyi u dzieci są chłoniaki (59\%), mięsaki prążkowanokomórkowe (13\%), nowotwory tarczycy (10\%), raki nosogardła (5\%), neuroblastoma (5\%), inne mięsaki $(4,5)$, nowotwory gruczołów ślinowych $(2,5 \%)$ oraz potworniaki złośliwe (1\%). Nowotwory w obrębie głowy i szyi najczęściej występują u dzieci powyżej 10 lat. Pacjenci z rozpoznaniem nowotworu głowy i szyi wymagają zaangażowania wielodyscyplinarnego zespołu lekarzy w celu przeprowadzenia szybkiej diagnostyki i wdrożenia odpowiedniego leczenia.

\section{IV.4 $\bullet$ Chłoniaki głowy i szyi u dzieci}

\section{Zawadzka-Głos, M. Dębska}

Klinika Otolaryngologii Dziecięcej Uniwersytetu Medycznego $w$ Warszawie

Chłoniaki są niejednorodną grupą nowotworów układu chłonnego i zajmują trzecie miejsce pod względem częstości występowania nowotworów litych u dzieci. Wyróżniamy chłoniaki ziarnicze (Hodgkin's Lymphoma-HL) oraz chłoniaki nieziarnicze (Non-Hodgkin’s Lymphoma-NHL). Chłoniaki Hodgkina mogą rozwijać się w każdym miejscu zawierającym tkankę chłonną, a także w narządach poza nimi, np. w kościach, płucach. Charakterystyczna dla HL jest obecność komórek Reed-Sternberga w badaniu histopatologicznym, które najczęściej wywodzą się z limfocytów B. Etiologia HL jest wciąż dyskutowana, ale uważa się, że istnieje związek pomiędzy zakażeniem wirusem Ebstein-Barra a występowaniem HL (około 40-50\% przypadków HL). Chłoniaki nieziarnicze (NHL) wywodzą się z limfocytów B, z limfocytów T oraz z komórek NK. Najliczniejszą grupę w Europie stanowią chłoniaki pochodzące $\mathrm{z}$ dojrzałych limfocytów typu B (B-NHL), w tym charakterystyczny dla wieku dziecięcego chłoniak Burkitta. Chłoniaki typu HL oraz NHL różnią się klinicznie pod wieloma względami. Chłoniaki NHL charakteryzują się większą rozległością i często zajmują szpik oraz ośrodkowy układ nerwowy. Średnia wieku zachorowania na NHL jest niższa niż na HL. Chłoniaki częściej występują u chłopców. Większość chłoniaków głowy i szyi u dzieci stanowią chłoniaki nieziarnicze (80\%).

Pierwotne zmiany chorobowe chłoniaków lokalizują się w obrębie głowy i szyi (42-60\%). Do typowych lokalizacji w obrębie głowy i szyi należy pierścień chłonny Waldeyera i węzły chłonne szyi, zaś w lokalizacji poza układem chłonnym: kości szczęki, żuchwy i podstawy czaszki, jama nosa i zatoki przynosowe, oczodół oraz ślinianki. Chłoniaki NHL z limfocytów B charakteryzują się wysokim wskaźnikiem proliferacji. Bardzo często wywiad dotyczący chłoniaków nieziarniczych jest bardzo krótki, nawet kilkudniowy i dotyczy zwłaszcza dzieci młodszych. Dlatego wczesne rozpoznanie bardzo często decyduje o powodzeniu leczenia. Chłoniaki NHL mają gorsze rokowanie niż chłoniaki HL, między innymi z powodu dużej dynamiki proliferacji, tendencji do zajmowania szpiku oraz OUN. 
Rokowanie zależy od stopnia zaawansowania choroby. Wczesne objawy chorób nowotworowych układu chłonnego mogą być przeoczone lub zbagatelizowane, gdyż są niecharakterystyczne i przypominają inne choroby wieku dziecięcego. Do wczesnych objawów należą: narastająca niedokrwistość, osłabienie, brak apetytu, spadek masy ciała, gorączka o nieustalonej etiologii, zmiany na błonie śluzowej jamy ustnej, niejasne bóle kostne. Często pierwszym objawem złośliwego chłoniaka nieziarniczego jest powiększenie pakietu węzłów chłonnych szyi, niebolesne i przebiegające bez podwyższonej temperatury lub jednostronne powiększenie migdałka podniebiennego. Chłoniaki głowy i szyi u dzieci mogą początkowo sugerować stan zapalny migdałków z rozpoczynającym się ropniem okołomigdałkowym, stan zapalny zatok głównie szczękowych. W przypadku zajęcia nosogardła wystąpią objawy charakterystyczne dla przerostu adenoidu, takie jak chrapanie, zaburzenie drożności nosa, mowa nosowa, wysięk w jamie bębenkowej. Jednak najczęstszym objawem chłoniaków jest limfadenopatia szyjna. Pakiet węzłów jest twardy i niebolesny, w chłoniakach nieziarniczych ulega szybkiemu powiększeniu. Pacjenci wymagają pilnej diagnostyki.

Słowa kluczowe: chłoniaki ziarnicze • chłoniaki nieziarnicze $\bullet$ dzieci

\section{IV.5 10:40-11:00 MEDA}

\section{Skuteczne leczenie alergicznego nieżytu nosa}

\section{A. Zawadzka-Krajewska}

Klinika Pneumonologii i Alergologii Wieku Dziecięcego

Uniwersytetu Medycznego $w$ Warszawie

Alergiczny nieżyt nosa (ANN) jest zespołem objawów klinicznych spowodowanych przewlekłym zapaleniem błony śluzowej i podśluzowej nosa w przebiegu IgE-zależnej reakcji alergicznej.

Rodzaj alergenu wywołującego objawy determinuje podział ANN na sezonowy lub całoroczny, czas trwania objawów klinicznych dzieli ANN na okresowy i przewlekły. Oba nieżyty nosa mogą mieć przebieg łagodny lub umiarkowany/ciężki. ANN sezonowy i okresowy nie są synonimami, podobnie jak ANN całoroczny i przewlekły.

Lokalny alergiczny nieżyt nosa charakteryzuje się objawami identycznymi jak ANN. Leczenie ANN obejmuje profilaktykę, farmakoterapię, swoistą immunoterapię alergenową i edukację pacjentów.

Do leków stosowanych w leczeniu nieżytów nosa należą: - leki przeciwhistaminowe podawane doustnie i na błonę śluzową nosa,

- glikokortykosteroidy podawane na błonę śluzową nosa,

- leki przeciwleukotrienowe,

- leki obkurczające naczynia błony śluzowej nosa.

Leki przeciwhistaminowe skuteczne są w leczeniu objawów spowodowanych działaniem histaminy. Mają niewielki wpływ na blokadę nosa. Mogą być podawane na błonę śluzową nosa lub doustnie, zmniejszają wówczas objawy nie tylko ze strony błony śluzowej nosa, ale również ze strony innych narządów. Zalecane jest podawanie leków przeciwhistaminowych drugiej generacji.

Glikokortykosteroidy donosowe (GKSn) mają silne działanie przeciwzapalne. Stosowane są przede wszystkich w tych przypadkach, w których dominującym objawem choroby jest upośledzenie drożności nosa spowodowane przewlekłym zapaleniem. GKSn zmniejszają ponadto świąd nosa, wyciek z nosa, redukują objawy oczne. Działanie GKSn jest bardziej skuteczne od działania leków przeciwhistaminowych i przeciwleukotrienowych.

GKSn nowej generacji są lekami bezpiecznymi, nie powodują atrofii błony śluzowej nosa, nie wpływają w sposób istotny na oś podwzgórzowo-przysadkowo-nadnerczową, nie mają zasadniczego wpływu na opóźnienie wzrastania. Zwykle objawy niepożądane mają charakter miejscowy i są następstwem działania propelantow, konserwantów, alkoholi i glikoli znajdujących się w pojemniku z lekiem. Ryzyko wystąpienia objawów ubocznych zmniejsza poprawna technika podawania leków na błonę śluzową nosa.

Przełomem w leczeniu ANN jest lek złożony, stanowiący połączenie preparatu przeciwhistaminowego i miejscowego glikokortykosteroidu. Lek zawiera propionian flutikazonu w dawce 50 mikrogramów i chlorowodorek azelastyny w dawce 137 mikrogramów, w unikatowej formulacji. Cechuje się lepszym efektem klinicznym niż podczas stosowania każdego $\mathrm{z}$ tych preparatów osobno.

Skuteczność leku jest:

- dwa razy wyższa w leczeniu objawów nosowych i ocznych niż standardowego leczenia pierwszego rzutu,

- dwa razy wyższa w leczeniu objawów nosowych i ocznych w porównaniu z propionianem flutikazonu,

- dwa razy wyższa w kontrolowaniu blokady nosa w porównaniu $\mathrm{z}$ propionianem flutikazonu.

Dzięki nowemu nośnikowi lek pozostaje długo na błonie śluzowej, nie spływa po tylnej ścianie gardła. Ma dobry profil bezpieczeństwa.

Leki przeciwleukotrienowe zmniejszają przede wszystkim blokadę nosa. Skuteczność ich jest dużo mniejsza niż GKSn. Zastosowanie znajdują w przypadkach, w których chory prezentuje dodatkowo objawy astmy.

Leki obkurczające naczynia błony śluzowej nosa stosowane są zwykle doraźnie lub krótkotrwale, zmniejszają blokadę nosa, nie działają na świąd nosa i napady kichania.

Jedyną metodą zapobiegającą dalszemu rozwojowi alergii i astmy jest swoista immunoterapia. Celem jej jest osiągnięcie tolerancji immunologicznej prowadzącej do złagodzenia lub ustąpienia objawów. 


\section{1:30-11:50 BIONORICA}

\section{Zapalenie zatok przynosowych chorobą cywilizacyjną dzieci, ze szczególnym uwzględnieniem ostrego zapalenia zatok}

\section{W. Golusiński}

Klinika Chirurgii Głowy, Szyi i Onkologii Laryngologicznej Uniwersytetu Medycznego w Poznaniu, Wielkopolskie Centrum Onkologii

\section{VIII.1 • Wady twarzy i czaszki - współczesne kierunki leczenia}

Sesja VI • 11:55-12:55 TEVA sesja firmowa

\section{Z. Dudkiewicz}

Centrum Leczenia Wad i Zaburzeń Rozwojowych FORMMED, Babice Nowe

W wystąpieniu zwrócono uwagę na skoki wzrostowe mózgu i jego wpływ na modelowanie czaszki w przypadku przedwczesnego zarastania szwów. Przedstawiono zasady postępowania chirurgicznego w różnych deformacjach czaszkowych i zasady podejmowania decyzji odnośnie leczenia chirurgicznego.

U dziecka z rozszczepem wargi i podniebienia dochodzi do przerwania tkanek miękkich w tym ciągłości układów mięśniowych i kostnych. Nos i jama ustna stanowią jedną jamę. Asymetria mięśniowa sprawia, że strona dominująca przeciąga łuk wyrostka zębodołowego, a skrzywiona przegroda niekiedy przemieszcza się około $1 \mathrm{~cm}$ w stosunku do linii środkowej. W przypadku rozszczepu obustronnego, kość przysieczna i wszystkie struktury z nią związane rosną w sposób niekontrolowany do przodu, ponieważ kompleks mięśni nosowo-wargowych i okrężnych ust jest obustronnie przerwany. Wada rośnie razem z dzieckiem. Dlatego też logiczne wydaje się jak najszybsze przywrócenie równowagi mięśniowej i zespolenie tkanek miękkich. W następnej kolejności wykonujemy przeszczep kości, tj. łączenie przerwanego łuku kostnego, co prowadzi do tzw. normalności. Pytanie brzmi: jak to wykonać, aby nie zaburzyć rosnących tkanek? Zwłaszcza, że współczesna wiedza wskazuje nam na znaczenie skoków wzrostowych, wieku rozwojowego i różnic w stosunku do wieku kalendarzowego. W wystąpieniu przedstawione będą współczesne polskie techniki chirurgiczne jak również późne wyniki leczenia w różnych typach wad rozszczepowych.
VIII.2 • Chirurgia rekonstrukcyjna ucha zewnętrznego u dzieci

\section{H. Skarżyński ${ }^{1,2}$}

${ }^{1}$ Klinika Oto-Ryno-Laryngochirurgii Instytutu Fizjologii

i Patologii Stuchu, Warszawa/Kajetany

${ }^{2}$ Światowe Centrum Stuchu IFPS $w$ Kajetanach

Ok. 12 tygodnia życia płodowego małżowina jest już dobrze uformowana i ma wykształcone wszystkie 18 elementów anatomicznych. Prawidłowy rozwój płodowy może zostać zaburzony w ok. 4-9 tygodniu ciąży w wyniku różnych czynników, takich jak: infekcje wirusowe, leki, promieniowanie jonizujące. Powstające wady, takie jak mikrocja czy anocja są następstwem nieprawidłowego rozwoju mezodermy I i II łuku skrzelowego.

Autor pracy przedstawia algorytm postępowania w wadach jednostronnych i obustronnych, uwzględniając optymalny rozwój słuchu, mowy i języka dziecka oraz wybór optymalnej strategii rekonstrukcji małżowiny.

$\mathrm{Na}$ przestrzeni 20 ostatnich lat przedstawiana była technika rekonstrukcji u dzieci z materiałów autogennych lub materiałów alloplastycznych. Podstawą postepowania chirurgicznego jest technika Nagaty w modyfikacji własnej autora. Wyniki rekonstrukcji małżowiny zostały ocenione zgodnie $\mathrm{z}$ opracowana ponad 10 lat temu klasyfikacja wg 4-stopniowej skali Skarżyńskiego.

W podsumowaniu zostaną przedstawione wyniki odległe rekonstrukcji małżowiny oraz różne warianty uzyskania w pełni wydolnego słuchu.

\section{VIII.3 • Wrodzona niedrożność dróg łzowych - diagnostyka i leczenie}

\author{
R. Różycki, A. Jakubaszek, D. Białas, \\ M. Michalik, M. Broda
}

Centrum Medyczne MML w Warszawie

Wstęp: Wrodzona niedrożność dróg łzowych stanowi częste schorzenie okulistyczne występujące u noworodków, niemowląt i małych dzieci. Wyniki badań wskazują, iż od 2 do 5\% noworodków przychodzi na świat z niedrożnością dróg łzowych. Celem pracy jest przegląd, na podstawie dostępnej literatury, metod diagnostycznych oraz terapeutycznych stosowanych w przypadku wystąpienia patologicznego łzawienia oraz przedstawienie własnych doświadczeń/wyników leczenia niedrożności dróg łzowych u dzieci.

Materiał i metody: Na podstawie przeglądu piśmiennictwa najczęstszą przyczyną występowania patologicznego łzawienia u dzieci (około 75\% przypadków) jest brak prawidłowego funkcjonowania zastawki Hasnera. Wrodzona niedrożność przewodu nosowo-łzowego w ponad 90\% przypadków ustępuje samoistnie lub pod wpływem masażu woreczka łzowego do pierwszego roku życia. Nadal sprawą dyskusyjną pozostaje stosowanie, w okresie 
niedrożności, miejscowej przewlekłej antybiotykoterapii. Antybiotyki hamują rozwój bakterii, nie prowadzą jednak do przywrócenia drożności przewodu nosowo-łzowego. W leczeniu najczęściej stosuje się zabieg sondowania dróg łzowych, który przywraca prawidłowy drenaż łez w ponad $90 \%$ przypadków.

W centrum Medycznym MML w latach $2010-2015$ z powodu niedrożności dróg łzowych i braku skuteczności wykonanych wcześniej procedur zabiegowych leczeniu chirurgicznemu poddanych zostało 38 dzieci w wieku od 9 miesiąca do 18 roku życia (średnio 12,3 lat). Wśród pacjentów były 24 dziewczynki i 14 chłopców. U wszystkich dzieci wykonano przezkanalikowe laserowe zespolenie workowo-nosowe (LDCR). Do wytworzenia przetoki używano lasera diodowego o długości fali $810 \mathrm{~nm}$, mocy $8 \mathrm{~W}$ przy średnim czasie aplikacji energii $112 \mathrm{~s}$. Zabiegi były przeprowadzane w znieczuleniu ogólnym.

Wyniki: Według analizy piśmiennictwa u badanych dzieci, u których mimo dwukrotnego sondowania (zgłębnikowania) dróg łzowych nie udaje się uzyskać ich drożności, w 35\% przypadków stwierdza się niedrożność przewodu nosowo-łzowego, w 15\% przypadków agenezję (wrodzony brak) punktów łzowych, w 10\% obecność wrodzonej przetoki, a u pozostałych $5 \%$ wrodzone defekty twarzoczaszki. W takich przypadkach stosowane są inne metody rekonstrukcji dróg łzowych.

W Centrum Medycznym MML uzyskaliśmy skuteczność zastosowanych procedur chirurgicznych u 30 pacjentów, co stanowi 79\% przypadków. Niewielkie łzawienie bez cech klinicznych niedrożności i konieczności reoperacji u 3 dzieci (8\%). U 5 pacjentów (13\%) musieliśmy wykonać ponowny zabieg operacyjny.

Wnioski: Sondowanie (zgłębnikowanie) prowadzi do udrożnienia przewodu nosowo-łzowego w 95\% przypadków. Odsetek powodzeń sondowania dróg łzowych maleje wraz z liczbą uprzednio wykonywanych procedur oraz wraz $\mathrm{z}$ wiekiem pacjenta. Leczenie chirurgiczne stanowi skuteczną metodę leczenia wrodzonych niedrożności dróg łzowych u dzieci.

\section{X.1 Aktualne wskazania do wszczepienia implantu ślimakowego u dzieci poniżej 1 roku życia}

\section{Present indications for cochlear implantation in children below 1 year of age}

\section{A. Fabijańska ${ }^{1,2}$, A. Lorens ${ }^{1,2}$, K. Kochanek ${ }^{1,2}$, H. Skarżyński ${ }^{1,2}$}

${ }^{1}$ Instytut Fizjologii i Patologii Stuchu, Warszawa/Kajetany

${ }^{2}$ Światowe Centrum Słuchu IFPS $w$ Kajetanach

Implanty ślimakowe są powszechnie uznaną, bezpieczną i wysoce skuteczną metodą rehabilitacji dzieci ze znacznymi i głębokim niedosłuchem odbiorczym. Obecnie FDA dopuszcza implantację ślimakową u dzieci od 12 miesiąca wzwyż, ale w niektórych ośrodkach na świecie implantuje się dzieci już od 6 miesiąca życia z bardzo dobrymi efektami w późniejszej rehabilitacji. Celem wczesnej implantacji jest zminimalizowanie negatywnych konsekwencji związanych $\mathrm{z}$ deprywacją sensoryczną w tzw. okresie krytycznym rozwoju mózgu.

W pracy przedstawiono restrospektywne wyniki wszczepienia implantu ślimakowego u 15 dzieci w wieku poniżej 12 miesięcy zoperowanych w Światowym Centrum Słuchu w okresie od 1 stycznia do 30 kwietnia 2013 r. Po 2 latach od aktywacji systemu $100 \%$ badanych dzieci osiągnęło 5 kategorię w skali SIR (Speech Intelligibility Rating Scale). W badanej grupie nie zaobserwowano większej częstości powikłań pooperacyjnych w porównaniu z dziećmi zaimplantowanymi w wieku późniejszym. Postęp, jaki dokonał się w ostatnich latach w technologii implantów ślimakowych, rozwój technik operacyjnych i wiedzy dotyczącej układu słuchowego, pozwala na rozszerzenie kryteriów kwalifikacji do tej procedury w kontekście obniżenia wieku implantacji poniżej 12 miesiąca życia.

Słowa kluczowe: implanty ślimakowe • głuchota prelingwalna

Key words: cochlear implants • prelingual deafness

\section{X.2 • Współczesne wskazania do implantów ucha środkowego u dzieci}

\author{
P. H. Skarżyński ${ }^{1,2,3,4,5}$, L. Olszewski ${ }^{1,3}$, \\ M. Porowski ${ }^{1,3}$, K. Osińska ${ }^{1,3}$, B. Król ${ }^{1,3}$, \\ H. Skarżyński ${ }^{1,3}$
}

\footnotetext{
${ }^{1}$ Instytut Fizjologii i Patologii Stuchu, Warszawa/Kajetany

${ }^{2}$ Zakład Niewydolności Serca i Rehabilitacji Kardiologicznej Uniwersytetu Medycznego $w$ Warszawie

${ }^{3}$ Światowe Centrum Stuchu IFPS $w$ Kajetanach

${ }^{4}$ Instytut Narzadów Zmysłów w Kajetanach

${ }^{5}$ Centrum Stuchu i Mowy „Medincus“ $w$ Kajetanach
}

W ostatnich latach nastąpił znaczący rozwój różnych technologii z zakresu urządzeń wszczepialnych w obrębie ucha środkowego. Pomimo coraz większego wyboru nowych technologii właściwa kompensacja niektórych postaci niedosłuchów jest nadal dosyć dużym wyzwaniem dla współczesnej otologii i audiologii. Bardzo często istnieją m.in. ograniczenia w stosowaniu klasycznych aparatów słuchowych lub urządzeń na przewodnictwo kostne. Oprócz względów czysto medycznych zdarza się, że pacjenci nie akceptują tych konwencjonalnych rozwiązań. Coraz częściej alternatywną opcją leczenia stają się urządzenia wszczepialne do ucha środkowego. Pozwalają one na rozwiązanie wielu problemów napotykanych $\mathrm{w}$ procesie protezowania $\mathrm{z}$ zastosowaniem konwencjonalnych protez słuchu. Celem tej pracy jest prezentacja możliwości i ograniczeń zastosowania u dzieci urządzeń typu Vibrant Soundbridge, MET, Carina, CODACS, Envoy Esteem, Ototronix. Z różnych względów niektóre $\mathrm{z}$ wymienionych urządzeń mają ograniczenia w zastosowaniu u dzieci. Urządzenia te zyskują coraz większą popularność, ale należy pamiętać, że optymalne wyniki są możliwe do osiągnięcia w przypadku posiadania multidyscyplinarnego zespołu. 


\section{X.3 • Współpraca międzyośrodkowa i chirurgiczne postępowanie $w$ wadach wrodzonych ucha wewnętrznego, środkowego i innych narządów}

H. Skarżyński ${ }^{1,2}$, M. Porowski ${ }^{1,2}$, L. Zawadzka-Głos ${ }^{3}$, M. Mrówka ${ }^{1,2}$

${ }^{1}$ Klinika Oto-Ryno-Laryngochirurgii Instytutu Fizjologii i Patologii Stuchu, Warszawa/Kajetany

${ }^{2}$ Światowe Centrum Stuchu IFPS $w$ Kajetanach

${ }^{3}$ Klinika Otolaryngologii Dziecięcej Uniwersytetu Medycznego $w$ Warszawie

Wstęp: Wady wrodzone narządu słuchu należą do jednych z najtrudniejszych wyzwań, z którymi spotyka się otochirurg. Niejednokrotnie wadom tym towarzyszą wrodzone nieprawidłowości innych narządów m.in. klatki piersiowej i jamy brzusznej. Inną grupą są dzieci dotknięte wadami wrodzonymi układu sercowo-naczyniowego, po operacjach kardiochirurgicznych, którym towarzyszy nabyty niedosłuch niejednokrotnie głębokiego stopnia, co kwalifikuje tych pacjentów do operacji wszczepienia implantu ślimakowego. Złożoność problemów wynikających z obecności licznych współistniejących schorzeń wymusza współpracę między licznymi specjalistami.

Materiał i metoda: $W$ prezentacji przedstawiono postępowanie interdyscyplinarne w przypadku grupy dzieci $\mathrm{z}$ nabytym głębokim niedosłuchem zmysłowo-nerwowym, wobec których zastosowano implant ślimakowy jako metodę jego leczenia. Dzieci te w wieku od 3 do 8 lat były po wcześniejszych operacjach chirurgicznych z powodu wrodzonych wad serca oraz układu oddechowego (przełożenie wielkich pni, niedorozwój komór, wrodzony zespół istotnego zwężenia tchawicy i obu oskrzeli głównych). Niektóre $\mathrm{z}$ nich miały wszczepiony również rozrusznik serca. W postępowaniu okołooperacyjnym brali udział liczni specjaliści, w tym otolaryngolog dziecięcy, otochirurg, kardiolog, anestezjolog. Potrzeba udziału tych specjalistów brała się z konieczności zapewnienia odpowiedniego przygotowania dziecka do operacji, przeprowadzenia samej operacji, jak i opieki okołooperacyjnej.

Wyniki: W prezentowanej grupie pacjentów wykonana operacja, jak również przebieg okołooperacyjny przebiegły bez żadnych powikłań zarówno chirurgicznych, jak i anestezjologicznych oraz ogólnych. Pobyt w szpitalu był stosunkowo krótki - wraz z operacją mieścił się w okresie tygodnia.

Wnioski: Współpraca międzyośrodkowa i interdyscyplinarna jest kluczowa w powodzeniu operacji dzieci ze złożonymi wadami słuchu oraz współistniejącymi wadami innych narządów. Postępowanie takie pozwala na zminimalizowanie ryzyka okołooperacyjnego oraz zmaksymalizowanie efektów leczenia.

Słowa kluczowe: wady narządu słuchu • wady serca • niedosłuch

\section{X.4 Zasady opieki inżynieryjnej nad dziećmi $z$ implantami słuchowymi}

\section{A. Lorens ${ }^{1,2}$, A. Obrycka ${ }^{1,2}$, A. Walkowiak ${ }^{1,2}$, T. Wiśniewski ${ }^{1,2}$, H. Skarżyński ${ }^{1,2}$}

${ }^{1}$ Instytut Fizjologii i Patologii Stuchu, Warszawa/Kajetany

${ }^{2}$ Światowe Centrum Stuchu IFPS $w$ Kajetanach

Wstęp: W wyniku interwencji chirurgicznej oraz innych działań wchodzących w zakres szeroko pojętej opieki nad dziećmi z implantami słuchowymi możliwa jest kompensacja wady słuchu i przeciwdziałanie negatywnym konsekwencjom niepełnosprawności (niesprawności) słuchowej. Zgodnie z najnowszymi zaleceniami organizacji audiologicznych opieka pooperacyjna po wszczepieniu implantu ślimakowego powinna być oparta na najnowszym modelu funkcjonalnym niepełnosprawności, który został stworzony na potrzeby Międzynarodowej Klasyfikacji, Funkcjonowania, Niepełnosprawności i Zdrowia (ang. International Classification of Functioning, Disability and Health, ICF)

Cel: Celem pracy było opracowanie modelu opieki inżynieryjnej nad dziećmi z implantami słuchowymi opartego na klasyfikacji ICF.

Material i metoda: Do opracowania modelu opieki inżynieryjnej wykorzystano tzw. listy kluczowe ICF (ang. core sets for hearing loss). Listy te zawierają spis poszczególnych funkcji i struktur ciała, form czynności i uczestnictwa, jak również wykaz czynników zewnętrznych związanych z niepełnosprawnością słuchową. Materiał stanowiła grupa ponad 4000 pacjentów implantowanych w Instytucie Fizjologii i Patologii Słuchu.

Wyniki: Podstawą opracowanego modelu opieki inżynieryjnej po wszczepieniu implantu jest odpowiednie ustawienie systemu implantu ślimakowego. W trakcie tego dopasowania przeprowadzane są indywidualnie dla każdego pacjenta dobór i optymalizacja parametrów stymulacji elektrycznej w celu kompensacji utraconych w konsekwencji niedosłuchu funkcji słuchowych. Wykorzystane są również inne strategie pomocowe ukierunkowane na przeciwdziałanie ograniczeniom $\mathrm{w}$ aktywności i uczestnictwie, takie jak treningi percepcyjne, wsparcie i edukacja.

Wnioski: Wprowadzenie do praktyki klinicznej związanej ze stosowaniem implantów ślimakowych modelu opieki inżynieryjnej opracowanego na podstawie Międzynarodowej Klasyfikacji Funkcjonowania, Niepełnosprawności i Zdrowia (ICF) ma na celu ograniczenie negatywnych skutków niepełnosprawności słuchowej, dotyczących funkcji struktur i ciała ludzkiego, aktywności i uczestnictwa. 


\section{X.5 • Indywidualny program rehabilitacji dziecka $\mathrm{z}$ implantem ślimakowym}

\section{An individual program of children's rehabilitation post cochlear implantation}

\section{A. Geremek-Samsonowicz ${ }^{1}$, A. Pankowska ${ }^{1}$, J. Rostkowska ${ }^{1}$, A. Barej ${ }^{1}$, H. Skarżyński' ${ }^{2}$}

${ }^{1}$ Klinika Rehabilitacji Instytutu Fizjologii i Patologii

Stuchu, Warszawa/Kajetany

${ }^{2}$ Światowe Centrum Stuchu IFPS w Kajetanach

Cel pracy: Wśród pacjentów objętych leczeniem z wykorzystaniem systemu implantu ślimakowego najważniejsze miejsce zajmują dzieci. Dzięki wczesnej diagnostyce i programowi badań przesiewowych słuchu u noworodków oraz dzieci w wieku wczesnoszkolnym czy szkolnym możemy proponować tę metodę leczenia różnym grupom pacjentów. Wszczepienie implantu stanowi moment rozpoczęcia rehabilitacji, ale jej program powinien uwzględniać: wiek pacjenta, umiejętności słuchowego odbioru sygnałów i mowy oraz poziom rozwoju mowy, języka i kompetencji komunikacyjnych nabyte do operacji, a co najważniejsze indywidualne predyspozycje każdego dziecka. Dla najmłodszych pacjentów, u których wada słuchu jest jedynym lub najistotniejszym dla ich rozwoju, problemem proponujemy podejście wpisane w Metodę Audytywno-Werbalną. Dla dzieci ze sprzężonymi niepełnosprawnościami program rehabilitacji związany $\mathrm{z}$ wszczepieniem implantu ślimakowego stanowi element wielospecjalistycznej opieki, prowadzonej zwykle poza naszym ośrodkiem. Naszym priorytetem jest natomiast wykorzystanie możliwości dostarczenia dziecku bodźca akustycznego i trening słuchowy obejmujący kolejne etapy rehabilitacji słuchu. Dla dzieci, u których wada słuchu obejmuje ograniczony dostęp lub jego brak do dźwięków zwłaszcza z obszaru wysokich częstotliwości, celem rehabilitacji będzie integracja wrażeń akustycznych i elektrycznych, zwłaszcza w obszarze percepcji mowy. U dzieci z głuchotą prelingwalną, które rozwijaja język w oparciu o kody manualne, priorytetem jest budowanie magazynu wrażeń słuchowych właściwych dzieciom ze słuchem prawidłowym tak, by na tej podstawie można było modyfikować metody rehabilitacji mowy lub uzupełniać rehabilitację prowadzoną na drodze wzrokowej o komponenty słuchowe. Integralnym elementem każdego postępowania w ramach pooperacyjnej rehabilitacji dziecka $\mathrm{z}$ implantem ślimakowym jest zaangażowanie i aktywna postawa rodziców, opiekunów oraz otoczenia. Działania praktyczne oraz edukacyjne skierowane do dorosłych uzupełniają pracę $\mathrm{w}$ gabinecie terapeuty.

Słowa kluczowe: rehabilitacja • dzieci • implant ślimakowy

\section{X.6 - Leczenie głębokich niedosłuchów u dzieci z chorobami układu krążenia - doświadczenia własne}

\section{Treatment of deep hearing loss in children with cardiovascular diseases - our experience}

\section{K. Amernik, E. Jaworowska, E. Grochowska- -Bochatyrewicz, T. Mikulski}

Klinika Otolaryngologii i Onkologii Laryngologicznej Pomorskiego Uniwersytetu Medycznego w Szczecinie

Cel pracy: Celem pracy było przedstawienie szczególnych warunków koniecznych w leczeniu głębokich niedosłuchów u dzieci z chorobami układu krążenia.

Materiał i metody: W latach 2008-2014 w Klinice Otolaryngologii PUM wykonano 38 zabiegów wszczepienia implantu ślimakowego u 37 chorych. Grupa dzieci liczyła 21 osób w wieku od 10 miesięcy do 12 lat. Spośród operowanych dzieci wykonano zabiegi u 4 pacjentów z dodatkowymi obciążeniami ze strony układu krążenia.

Wyniki: Czas od zabiegów wynosił od 2 do 6 lat. Dla wszystkich operowanych dzieci zapewniona była opieka na oddziale Intensywnej Opieki Medycznej dla Dzieci. U jednego z pacjentów z zespołem Jarvel i Lange Nielsena przeprowadzono wybudzanie po zabiegu na oddziale IOM z uwagi na zwiększone ryzyko arytmii oraz zatrzymania krążenia w mechanizmie migotania komór. Również u tego dziecka konieczne było zabezpieczenie możliwości defibrylacji przez cały czas trwania procedury chirurgicznej. Ryzyko migotania komór było najwyższe podczas wprowadzania do znieczulenia ogólnego pomiarów nRT oraz podczas wybudzania dziecka.

Wnioski: Dzieci z głębokim niedosłuchem czuciowo-nerwowym mogą w sposób bezpieczny być poddane procedurze implantacji ślimakowej, jednak konieczne jest wówczas zabezpieczenie opieki pooperacyjnej na oddziale intensywnej terapii dla dzieci.

Słowa kluczowe: głuchota • głęboki niedosłuch • implanty ślimakowe $\bullet$ choroby układu sercowo-naczyniowego

\section{XII.1 • Unaczynienie migdałka podniebiennego u płodu ludzkiego}

\section{Vasculature of the Human Fetus Palatine Tonsil in scanning electron microscopy}

\author{
J. Składzieńn ${ }^{1}$, K. Zagórska-Świeży ${ }^{1}$, J. Litwin ${ }^{2}$ \\ ${ }^{1}$ Katedra i Klinika Otolaryngologii Collegium Medicum \\ Uniwersytetu Jagiellońskiego $w$ Krakowie \\ ${ }^{2}$ Katedra Histologii Collegium Medicum Uniwersytetu \\ Jagiellońskiego $w$ Krakowie
}

U płodów ludzkich uzyskanych drogą spontanicznego poronienia nastrzykano układ naczyń, wykonano preparaty 
pokazujące odlewy naczyń krwionośnych unaczynienia migdałków podniebiennych. Uwidoczniono naczynia tętnicze i żylne migdałka podniebiennego i tworzących się krypt w okresie, kiedy nie było funkcji pokarmowych, a więc np. żucia i połykania.

\section{XII.2 - Stara metoda, nowe narzędzie. Zastosowanie urządzenia do wideorynoskopii tylnej w celu oceny nosogardła, w szczególności oceny migdałka gardłowego. Doniesienia wstępne}

\section{Old method, new tool. Usefulness of posterior videorynoscopy for nasopharynx examination, especially pharyngeal tonsil. Preliminary report}

\section{J. Sova, J. Kijewski}

Centrum Medyczne Dąbrowa-Dąbrówka w Gdyni

Cel pracy: Przedstawienie dostępnych metod badania nosogardła, a w szczególności możliwości oceny migdałka gardłowego.

Material i metody: W pracy przedstawiono dotychczasowe metody oceny nosogradła u dzieci oraz nowe urządzenie ENTviewer. W urządzeniu tym wykorzystano system mikrokamer i diody led oraz bezprzewodowy zapis cyfrowy uzyskanych obrazów. Dzięki zastosowaniu najnowszych technologii bez dodatkowego oświetlenia zewnętrznego obraz nosogardła utrwalany jest na komputerze. Badanie trwa bardzo krótko, przez co jest dobrze tolerowane nawet $\mathrm{u}$ najmłodszych pacjentów. Dzięki zapisowi cyfrowemu możliwa jest późniejsza poklatkowa ocena oraz archiwizacja otrzymanego filmu.

Wyniki: Autorzy przedstawią obrazy uzyskane w urządzeniu podczas badania $\mathrm{w}$ okresie przedoperacyjnym $\mathrm{w}$ porównaniu do śródoperacyjnej oceny uzyskanego materiału podczas adenotomii. Omawiają też trudności oraz możliwości wykorzystania wideorynoskopii tylnej z zapisem cyfrowym w badaniu migdałka gardłowego. Przedstawiają również odciągacz podniebienia, który może ułatwić to badanie.

Wnioski: Zastosowanie nowoczesnych rozwiązań z zakresu optoelektroniki, techniki i informatyki umożliwiło stworzenie urządzenia do oceny nosogardła w badaniu - wideorynoskopii tylnej. Wideorynoskopia tylna jest przydatna w ocenie nosogardła i migdałka gardłowego. Wprowadzenie nowego rozwiązania - odciągacza podniebienia - może ułatwić ocenę nosogardła. Niezbędne jest opracowanie systemu oceny względnej migdałka gardłowego w korelacji do wymiarów twarzoczaszki. Zostanie to przedstawione w przyszłych doniesieniach. Istotna jest ocena kliniczna nosogradła przed leczeniem operacyjnym w aspekcie kształtu migdałka gardłowego, jak i innych chorób spotykanych w tej lokalizacji.

Słowa kluczowe: wideorynoskopia tylna • ocena migdałka gardłowego
XII.3 • Przerost migdałka językowego jako przyczyna bezdechów

\section{Lingual tonsil hypertrophy as a cause of sleep apnea - a case report}

\section{Badełek-Izdebska, M. Dębska, L. Zawadzka-Głos}

Klinika Otolaryngologii Dziecięcej Uniwersytetu Medycznego $w$ Warszawie

Migdałek językowy to skupisko tkanki limfatycznej znajdującej się na nasadzie języka. Stanowi część tzw. pierścienia gardłowego chłonnego Waldeyera. Migdałek językowy może być miejscem rozwoju nowotworów złośliwych, np. chłoniaków lub stanów zapalnych (angina migdałka językowego). Najczęstszymi objawami powiększenia migdałka językowego są dysfagia oraz bezdechy. Przedstawiono przypadek 9-letniego chłopca $\mathrm{z}$ bezdechami i chrapaniem po kilkukrotnych operacjach przerośniętego migdałka gardłowego i podniebiennych. W wykonanych badaniach CT stwierdzono nieregularną zmianę w okolicy nasady języka, dochodzącą do nagłośni. W wykonanej direktoskopii usunięto tkanki z nasady języka, nagłośni oraz bocznych ścian gardła dolnego.

W badaniu histopatologicznym stwierdzono utkanie adenoidalne. Pooperacyjną drożność dróg oddechowych zabezpieczono poprzez wykonanie tracheotomii. Przy wypisie bez zaburzeń oddychania w postaci bezdechów i chrapania.

Analiza powyższego przypadku pokazuje, że przerost migdałka językowego dość rzadko będący przyczyną bezdechów u dzieci, powinien być brany pod uwagę podczas diagnostyki, a leczenie operacyjne i badanie histopatologiczne usuniętych tkanek pozwala na postawienie ostatecznego rozpoznania.

Słowa kluczowe: migdałek językowy • bezdechy • przerost migdałka

\section{XII.4 • Diagnostyka limfadenopatii szyjnej} u dzieci

\section{Diagnosis of cervical lymphadenopathy in children}

\section{B. Skotnicka ${ }^{1,2}$, K. Trzpis ${ }^{1,2}$, M. Krawczuk-} -Rybak ${ }^{1,2}$, E. Hassmann-Poznańska ${ }^{1,2}$

\footnotetext{
${ }^{1}$ Klinika Otolaryngologii Dziecięcej Uniwersytetu Medycznego w Bialymstoku

${ }^{2}$ Klinika Onkologii i Hematologii Dziecięcej Uniwersytetu Medycznego w Białymstoku
}

Cel pracy: Celem pracy jest ocena czynników klinicznych, wyników badań dodatkowych, w tym ultrasonograficznego, jako kryteriów prognostycznych wskazujących na konieczność postępowania inwazyjnego w diagnostyce limfadenopatii szyjnej u dzieci. 
Materiał i metody: Ocena retrospektywna dokumentacji medycznej 62 dzieci w wieku od 6 miesięcy do 17,5 roku (śr. 10,7) hospitalizowanych w Klinice Onkologii i Laryngologii Dziecięcej UM w Białymstoku w latach 2011-2013. Diagnostyka obejmowała badanie przedmiotowe i radiologiczne (USG szyi, jamy brzusznej, rtg klatki piersiowej). W badaniach laboratoryjnych oceniano parametry zapalne, LDH, wykonywano badania serologiczne w kierunku chorób odzwierzęcych i wirusowych (CMV, EBV) oraz niekiedy próbę RT 23 . Jedynie w wybranych przypadkach przeprowadzano biopsję chirurgiczną.

Wyniki: Najczęściej okres utrzymywania się powiększonych węzłów chłonnych szyi wynosił 2-6 miesięcy. Najczęstsza lokalizacja to okolica podżuchwowa i żyły szyjnej, zmiany obustronne. Jedynie $16 \%$ dzieci miało zmiany jednostronne, tworzące pakiety lub wielkości powyżej 3 $\mathrm{cm}$. W wynikach badań dodatkowych dominowały miernie podwyższone parametry zapalne (27\%), u $21 \%$ dzieci stwierdzono podwyższony poziom LDH. Aż $37 \%$ chorych miało dodatnie wyniki w badaniach przeciwciał anty CMV w klasie IgG. W badaniach USG stwierdzano jedynie zatokowy typ unaczynienia w obrębie węzłów chłonnych. Nie potwierdzono obecności limfadenopatii o etiologii nowotworowej.

Wnioski: Wykonany zakres badań diagnostycznych jest wystarczający dla oceny etiologii powiększonych węzłów chłonnych szyi.

Słowa kluczowe: limfadenopatia szyjna - dzieci • diagnostyka

\section{XII.5 - Torbiele dermoidalne i przetoki linii pośrodkowej głowy i szyi u dzieci}

\section{Dermoidal cysts and fistulae of the head and neck midline in children}

\section{Piszcz, B. Skotnicka, E. Hassmann- -Poznańska, E. Gościk, J. Reszeć}

Klinika Otolaryngologii Dziecięcej Uniwersytetu Medycznego w Białymstoku

Cel pracy: Torbiele dermoidalne i przetoki to łagodne zmiany pochodzenia naskórkowego, w 7\% zlokalizowane w obrębie głowy i szyi. Mają charakter zmian wrodzonych, ujawniających się klinicznie w linii pośrodkowej ciała. Najczęściej (70\%) diagnozowane są u dzieci poniżej 5 roku życia. Celem pracy była analiza przypadków klinicznych torbieli dermoidalnych i przetok linii pośrodkowej głowy i szyi u dzieci leczonych w Klinice Otolaryngologii Dziecięcej UM w Białymstoku w latach 1995-2015.

Material i metody: Przeprowadzono analizę dokumentacji medycznej dzieci z torbielami oraz przetokami linii pośrodkowej głowy i szyi, diagnozowanych i leczonych operacyjnie w Klinice Otolaryngologii Dziecięcej UM w Białymstoku. Przedstawiono przegląd literatury dotyczący tego tematu.
Wyniki: W klinice leczono 43 pacjentów z omawianymi anomaliami rozwojowymi w obrębie głowy i szyi, w tym 17 dzieci z torbielami dermoidalnymi, 19 dzieci $z$ torbielami epidermalnymi, 5 dzieci z przetokami i torbielami grzbietu nosa oraz 3 dzieci z przetokami linii środkowej szyi.

Najczęstszą lokalizacją torbieli była okolica przednia szyi i dno jamy ustnej. W diagnostyce wykorzystywano badanie ultrasonograficzne i tomografię komputerową. Wszystkich chorych leczono chirurgicznie.

Wnioski: Rozpoznanie torbieli dermoidalnych musi być brane pod uwagę w diagnostyce guzów głowy i szyi u dzieci. Przetoki grzbietu nosa są rzadko spotykanym zaburzeniem rozwojowym. Radykalne usunięcie wrodzonych zmian patologicznych linii pośrodkowej głowy i szyi $\mathrm{u}$ dzieci jest warunkiem zabezpieczającym przed nawrotem choroby.

Słowa kluczowe: torbiele dermoidalne $\bullet$ przetoki $\bullet$ zaburzenia rozwojowe linii pośrodkowej głowy i szyi

\section{XII.6 - Torbiele wrodzone szyi - diagnostyka i leczenie w Klinice Otolaryngologii Dziecięcej w Poznaniu}

\section{Congenital neck cysts - diagnosis and treatment in Pediatric ENT Department in Poznan}

\section{B. Pucher, J. Sroczyński, J. Kolasińska-Lipińska, M. Kotowski, M. Ryglewicz, J. Szydłowski}

Klinika Otolaryngologii Dziecięcej Uniwersytetu Medycznego w Poznaniu

Cel pracy: Celem pracy jest ocena skuteczności leczenia operacyjnego wrodzonych torbieli szyi u dzieci w zależności od zastosowanej techniki operacyjnej, a także analiza przebiegu okresu pooperacyjnego oraz liczby nawrotów z koniecznością reoperacji.

Materiał i metody: Analizie retrospektywnej poddano grupę 51 pacjentów $\mathrm{z}$ wrodzonymi torbielami szyi operowanych w Klinice Otolaryngologii Dziecięcej w Poznaniu w latach 2011-2015. U wszystkich pacjentów przed zabiegiem operacyjnym wykonano diagnostykę obrazową (USG/MR), natomiast po zabiegu materiał oddano do badania histopatologicznego.

Wyniki: Największą grupę stanowiły dzieci z torbielą środkową szyi - 35 pacjentów, kolejno z torbielą boczną szyi - 16, przetoką boczną szyi - 5 oraz przetoką środkową szyi - 4. W badanym materiale u 2 pacjentów $\mathrm{z}$ przetoką środkową szyi zabieg był reoperacją, 1 pacjent $\mathrm{z}$ przetoką boczną szyi wymagał 2 reoperacji.

Wnioski: Wg licznych autorów najczęściej przyczyną wystąpienia nawrotu torbieli jest pozostawienie fragmentu jej torebki. Ryzyko wzrasta w przypadku obecności przetoki wewnętrznej, odczynu zapalnego w tkankach lub zrostów pozapalnych utrudniających precyzyjne preparowanie. 
Słowa kluczowe: torbiel środkowa szyi • torbiel boczna szyi • leczenie operacyjne $\bullet$ dzieci

\section{XII.7 • Przewlekłe infekcje górnych dróg oddechowych i reakcje alergiczne a dysbioza jelitowa u dzieci}

\section{Chronic infections of the upper respiratory tract and allergic reactions related to intestinal dysbiosis in children}

\section{Kurczabińska-Luboń ${ }^{1,2}$, H. Kawalski ${ }^{2}$} ${ }^{1}$ Wyższa Szkoła Nauk Stosowanych w Rudzie Śląskiej
${ }^{2}$ Lecznica Dzieci i Dorosłych - Szpital im. I. Mościckiego
${ }_{\text {w Chorzowie }}$

Cel pracy: Współczesna interpretacja zależności pomiędzy występowaniem przewlekłych infekcji górnych dróg oddechowych i reakcji alergicznych a dysbiozą jelit na podstawie analizy aktualnych doniesień naukowych.

Materiał i metody: Analiza aktualnych doniesień naukowych.

Wyniki: Istnieje zależność pomiędzy dysbiozą jelit i stanem zapalnym błony śluzowej a przewlekłymi infekcjami ORL u dzieci.

Wnioski: Zaburzenia mikrobioty jelitowej i towarzyszący im stan zapalny błony śluzowej jelit może stawać się bezpośrednią przyczyną aktywacji układu immunologicznego oraz przyczyniać się do alergizacji, jak również wpływać na przewlekłości infekcji u dzieci.

Słowa kluczowe: mikrobiota jelitowa • przewlekłe infekcje laryngologiczne $\bullet$ dysbioza jelitowa

\section{XII.8 • Zespół ogólnoustrojowej reakcji zapalnej w schorzeniach laryngologicznych - opis dwóch przypadków}

\section{Systemic inflammatory response syndrome in diseases of ENT - two case reports}

\section{Cofała, I. Bielecki, A. Krzemień-Gabriel}

Oddział Laryngologii, Górnośląskie Centrum Zdrowia Dziecka Śląskiego Uniwersytetu Medycznego w Katowicach

Cel pracy: Przedstawienie aktualnego stanu wiedzy na temat uogólnionej reakcji zapalnej (SIRS) występującej $\mathrm{w}$ przebiegu chorób laryngologicznych.

Materiał i metody: Przegląd piśmiennictwa i omówienie dwóch przypadków dzieci leczonych w Oddziale Laryngologii Górnośląskiego Centrum Zdrowia Dziecka w Katowicach, u których stwierdzono SIRS.
Wyniki: Pierwszy przypadek dotyczy 5-letniej dziewczynki leczonej z powodu ostrego zapalenia ucha środkowego, powikłanego zapaleniem wyrostka sutkowatego i posocznicą. Drugi przypadek to 15 -letni chłopiec leczony z powodu ostrego zapalenia zatok przynosowych, powikłanego posocznicą $\mathrm{z}$ wytworzeniem ropni przerzutowych w kończynach dolnych.

Wnioski: Ogólnoustrojowa reakcja zapalna organizmu jest spowodowana przez czynniki o różnej etiologii, charakteryzuje się szybkim przebiegiem i prowadzi do niewydolności ważnych dla funkcji życiowych pacjenta narządów. W praktyce laryngologicznej takie reakcje są najczęściej wywoływane przez czynnik mikrobiologiczny, prowadząc do posocznicy. Są to stany bezpośredniego zagrożenia życia, które wymagają szybkiego rozpoznania, podjęcia leczenia oraz stałego monitorowania stanu klinicznego pacjenta.

Słowa kluczowe: SIRS • choroby laryngologiczne

\section{XII.9 - Niepowodzenia w leczeniu ostrego zapalenia ucha środkowego - analiza flory bakteryjnej}

\section{Treatment failures in acute otitis media - analysis of the bacterial flora}

\section{P. Żychowski ${ }^{1}$, E. Mazur ${ }^{2}$, I. Korona-Głowniak ${ }^{3}$,} G. Mielnik-Niedzielska', M. Kozioł-Montewka ${ }^{2}$

\footnotetext{
${ }^{1}$ Klinika Otolaryngologii Dziecięcej, Foniatrii i Audiologii Uniwersytetu Medycznego w Lublinie

${ }^{2}$ Zakład Mikrobiologii Lekarskiej Uniwersytetu Medycznego $w$ Lublinie

${ }^{3}$ Zakład Mikrobiologii Farmaceutycznej Uniwersytetu Medycznego w Lublinie
}

Cel pracy: Celem pracy była ocena flory bakteryjnej jamy bębenkowej w przypadku niepoddającego się leczeniu OZUŚ.

Materiał i metody: Badaniem objęto 38 dzieci leczonych operacyjnie w Klinice Otolaryngologii Dziecieccej, Foniatrii i Audiologii UM w Lublinie z powodu OZUŚ w latach 2010-2014. Za wskazanie do tympanocentezy/drenażu wentylacyjnego jamy bębenkowej przyjęto niepowodzenie leczenia: brak poprawy po zastosowaniu co najmniej 48-godzinnej antybiotykoterapii lub nawrót OZUŚ w czasie krótszym niż 30 dni od zakończenia leczenia poprzedniego epizodu choroby. Uzyskaną wydzielinę z jamy bębenkowej, wymaz z nosogardła i gardła środkowego poddano badaniom mikrobiologicznym. Analizowano także uzyskane $\mathrm{z}$ wywiadu dane środowiskowe, dotychczasową antybiotykoterapię, zastosowane szczepienia profilaktyczne.

Wyniki: W materiale z ucha środkowego u 23 (60,5\%) pacjentów stwierdzono bakterie patogenne. Tylko w 3 przypadkach była to flora mieszana. Dominujace bakterie to Streptococcus pneumoniae oraz Haemophilus influenzae - obie potwierdzono w 10 posiewach. Serotyp 19F pneumokoków stwierdzono w 4 przypadkach, podobnie serotyp 14 , u pozostałych dwóch - 6B oraz $23 \mathrm{~F}$. $70 \% \mathrm{z}$ nich stanowiły szczepy wielooporne. Oporność na antybiotyki 
stwierdzono u 6 spośród 10 wyhodowanych szczepów Haemophilus influenzae.

Wnioski: Niepoddające się leczeniu OZUŚ jest często spowodowane przez wielooporne szczepy bakterii i wymaga antybiotykoterapii wykraczającej poza rekomendacje. Szczepienia uodparniające przeciwko Streptococcus pneumoniae mogłyby pozytywnie wpłynąć na częstość występowania lekoopornych infekcji ucha środkowego.

Słowa kluczowe: ostre zapalenie ucha środkowego • flora bakteryjna • lekooporność • Streptococcus pneumoniae - szczepienia

\section{XII.10 Izolowane patologie zatoki klinowej u dzieci}

\section{Isolated sphenoid sinus disease in children}

\section{Kotowski, J. Kolasińska-Lipińska, J. Sroczyński, B. Pucher, J. Szydłowski}

Klinika Otolaryngologii Dziecięcej Uniwersytetu Medycznego w Poznaniu

Cel pracy: Izolowane patologie zatoki klinowej są rzadko występującymi nieprawidłowościami w populacji dziecięcej. Ze względu na brak charakterystycznych objawów klinicznych oraz algorytmów postępowania stwarzają niejednokrotnie znaczące trudności diagnostyczne i lecznicze.

Celem pracy było określenie spektrum zmian chorobowych mogących manifestować się w sposób wybiórczy w zatoce klinowej, próba oceny wskazań do leczenia operacyjnego oraz prezentacja wyników leczenia w tej grupie chorych.

Materiał i metody: Grupę badaną stanowiło 10 pacjentów z potwierdzoną radiologicznie izolowaną patologią zatoki klinowej, leczonych operacyjnie w Klinice Otolaryngologii Dziecięcej UM w Poznaniu w latach 2013-2015. Dokonano analizy retrospektywnej danych klinicznych zawartych w dokumentacji medycznej pacjentów ze szczególnym uwzględnieniem charakteru i czasu trwania zgłaszanych dolegliwości, wyników badań obrazowych, dostępu operacyjnego, wyników badań histopatologicznych i katamnezy.

Wyniki: Izolowane patologie zatoki klinowej dotyczyły chorych w wieku od 7 do 17 roku życia (średnia 11 r.ż). Dominującym objawem w grupie badanej pozostawały dolegliwości bólowe głowy. Stwierdzone nieprawidłowości obejmowały zmiany o charakterze zapalnym, nowotworowym oraz zaburzenia rozwojowe. Leczenie operacyjne miało charakter niepowikłany we wszystkich przypadkach i skutkowało poprawą kliniczną u ponad $60 \%$ pacjentów.

Wnioski: Izolowane patologie zatoki klinowej reprezentują szereg różnorodnych histologicznie zmian chorobowych. Wnikliwa diagnostyka przedoperacyjna, której nieodzowny element stanowią badania obrazowe, pozwala na wybór właściwego dostępu i zakresu leczenia operacyjnego.
XII.11 • Czy u dzieci jednostronny guz jamy nosa to polip?

\section{Unilateral masses in child's nose - polyp?}

\author{
M. Dębska, L. Zawadzka-Głos, \\ K. Raczkowska-Łabuda
}

Oddział Otolaryngologii Dziecięcej Uniwersytetu Medycznego $w$ Warszawie

Cel pracy: Analiza materiału dotyczącego jednostronnych guzów nosa u pacjentów Kliniki Otolaryngologii Dziecięcej Warszawskiego Uniwersytetu Medycznego. Charakterystyka patologii.

Materiał i metody: Retrospektywna analiza historii chorób 55 pacjentów Kliniki Otolaryngologii Dziecięcej Warszawskiego Uniwersytetu Medycznego (34 chłopców i 21 dziewcząt), hospitalizowanych w latach 2006-2014. W podanym przedziale czasu wszyscy pacjenci zostali zakwalifikowani do chirurgicznej interwencji diagnostycznej i leczniczej.

Wyniki: Średnia wieku wszystkich operowanych dzieci wynosiła 8,64 roku. Najmłodszy pacjent ukończył 1 miesiąc życia, a najstarszy 17 lat. Do analizowanej grupy zakwalifikowano chorych ze zmianami łagodnymi, w tym z jednostronnymi polipami nosa (50 pacjentów) oraz ze zmianami złośliwymi (5 pacjentów). Średnia wieku pacjentów po wykluczeniu grupy ze zmianami polipowatymi (18 chorych w wieku średnio 12,1 lat) wynosiła 6,96 lat. Analiza wyników histopatologicznych wykazała: 18 przypadków zmian polipowatych, 7 naczyniaków kapilarnych (średnia wieku 9 lat), 5 naczyniakowłókniaków młodzieńczych (średnia wieku 14 lat), 4 włókniaki (średnia wieku 6,75 lat), 4 wyrośla skórne (średnia wieku 9 miesięcy), 2 glejaki nosa ( 3 $\mathrm{m}$-ce, 6 lat) oraz incydentalne: Cranial fascitis, Hamartoma, Meningocele, Xanthogranuloma juvenile, Tumor mi$x t u s$, Mucocele, Psammomatoid Active Ossyfying Fibroma, Chłoniak Burkitta, NHLB, Rhabdomyosarcoma embryonale, Neuroblastoma, Carcinoma planoepitheliale.

Wnioski: 1. Charakter jednostronnych guzów nosa u dzieci jest współzależny od wieku i płci pacjenta. 2. W grupie noworodków i niemowląt dominują guzy typu wyrośli skórnej, naczyniaków, przepukliny oponowo-mózgowej oraz glejaka. 3. U dzieci w wieku przedszkolnym (9 r.ż.) są polipy. 4. U nastoletnich chłopców z nawracającymi krwawieniami z nosa można podejrzewać naczyniakowłókniaka młodzieńczego. 5. Pomimo tego, że odsetek złośliwych guzów jednostronnych nosa nie przekracza $10 \%$, powinny one zostać uwzględnione w diagnostyce różnicowej. 6 . Jednostronny ,polip nosa” u dziecka nie zawsze jest zmianą o łagodnym charakterze.

Słowa kluczowe: guzy jamy nosa $\bullet$ nowotwory nosa $\bullet$ nowotwory u dzieci • polipy

Słowa kluczowe: zatoka klinowa • dzieci 
XII.12 • Grzybicze zapalenie zatok przynosowych u dzieci - opis przypadku

\section{Fungal sinusitis in children - a case report}

\section{Dec, I. Bielecki, M. Mandera, A. Klimczak}

Oddział Laryngologii, Oddział Neurochirurgii, Górnoślaskie Centrum Zdrowia Dziecka Śląskiego Uniwersytetu Medycznego w Katowicach

Cel pracy: Przedstawienie aktualnego stanu wiedzy na temat grzybiczego zapalenia zatok u dzieci.

Material i metody: Przegląd piśmiennictwa i opis jednego przypadku 4-letniego dziecka.

Wyniki: Przedstawiono przypadek 4-letniego chłopca przyjętego do Oddziału Neurochirurgii z powodu podejrzenia ropniaka nadtwardówkowego w okolicy czołowej. W badaniach obrazowych w obrębie zatok przynosowych stwierdzono masywne zmiany zapalne. U dziecka przeprowadzono operację neurochirurgiczną, ewakuowano krwiak, nie potwierdzając obecności ropniaka. Jednoczasowo laryngolog wykonał operację metodą FESS. Na podstawie obrazu śródoperacyjnego i wyniku histopatologicznego rozpoznano grzybicze zapalenie zatok. Przebieg pooperacyjny był niepowikłany; kontynuowano leczenie meronemem i flukonazolem przez $21 \mathrm{dni}$. Pacjenta wypisano do domu w stanie dobrym, bez deficytów neurologicznych i objawów zakażenia.

Wnioski: Zapalenie zatok przynosowych o etiologii grzybiczej jest rzadką postacią tego schorzenia, która charakteryzuje się często nietypowym przebiegiem oraz dużym ryzykiem powikłań.

Słowa kluczowe: zapalenie zatok • grzybica • dzieci 


\section{SALA A}

\section{XIII.1 • Chirurgia endoskopowa w otologii u dzieci}

\section{K. Niemczyk, E. Karchier, R. Bartoszewicz, K. Morawski}

Katedra i Klinika Otolaryngologii Uniwersytetu Medycznego $w$ Warszawie

Wstęp: Endoskopia w otologii znajduje zastosowanie zarówno w diagnostyce przedoperacyjnej, jak i w chirurgii. W obu przypadkach wykorzystywane są możliwości szerszego wglądu do struktur ucha środkowego i ograniczenie zakresu otwarcia chirurgicznego. Szczególnie ważnym zastosowaniem technik endoskopowych jest ocena i obserwacja kieszonek retrakcyjnych a śródoperacyjnie usuwanie perlaka i kontrola jej doszczętności oraz wykonywanie rekonstrukcji układu przewodzącego.

Materiał i metody: Autorzy oceniali w oparciu o przyjętą skalę AVS wartość technik wykonywanych w optyce mikroskopowej i makroskopwej u dzieci operowanych z powodu przewlekłego perlakowego zapalenia ucha środkowego. Analizowano możliwość kontroli zakresu usuwanych zmian perlakowych w różnych częściach jamy bębenkowej oraz wykonywanie rekonstrukcji. We wszystkich przypadkach operacje wykonywano techniką zamkniętą z tympanotomią tylną.

Wyniki: Stwierdzono, że tylko w optyce endoskopowej można zawsze w pełni usunąć i kontrolować zmiany w zachyłku przednim epitympanum, przednią część jamy bębenkowej oraz w zatoce bębenkowej. Stwierdzono, że do tych celów, u dzieci, optymalne jest zastosowanie endoskopów o średnicy $2,7 \mathrm{~mm}$ i kącie patrzenia $45^{\circ}$. Mniej jednoznaczne wyniki uzyskano przy porównaniu ossikuloplasyk wykonywanych endoskopowo i w mikroskopie. Lepsza widoczność dotyczyła wewnętrznej części błony bębenkowej i położenia przeszczepu i głowy protezki, jednak okolica okienka owalnego trudna była do oceny ze względu na trudności w uzyskaniu porównywalnej do mikroskopu ostrości obrazu.

Wnioski: Autorzy podkreślają, że technika chirurgii endoskopowej ucha pozwala na lepszą kontrolę usunięcia zmian perlakowych oraz na dobrą kontrolę ustawienia łańcucha kosteczek słuchowych lub jego zamienników - protezek. Technika chirurgii endoskopowej może być obecnie polecana jako wspomagająca operacje mikroskopowe. Rozwinięcie chirurgii endoskopowej ucha w przyszłości może doprowadzić do ograniczenia zakresu otwarcia w wielu sytuacjach klinicznych.

Słowa kluczowe: cholesteatoma $\bullet$ middle ear surgery $\bullet$ endoscopy assisted surgery

\section{XIII.2 • Perlak w przewlekłym zapaleniu ucha środkowego w ocenie mikroskopu elektronowego skaningowego}

\section{Cholesteatoma otitis media chronica in scanning electron microscopy}

\section{J. Składzień ${ }^{1}$, K. Zagórska-Świeży ${ }^{1}$, J. Litwin ${ }^{2}$}

\footnotetext{
${ }^{1}$ Katedra i Klinika Otolaryngologii Collegium Medicum

Uniwersytetu Jagiellońskiego w Krakowie

${ }^{2}$ Katedra Histologii Collegium Medicum Uniwersytetu Jagiellońskiego $w$ Krakowie
}

W trakcie wykonywania rożnych rodzajów operacji tympanoplastycznych w przebiegu przewlekłego, perlakowego zapalenia ucha środkowego u dzieci i u chorych dorosłych, usuniętego perlaka podzielono na dwie części. Jedną posłano do oceny histopatologicznej, uzyskując potwierdzenie rozpoznania perlaka, a drugą oceniono w mikroskopie elektronowym skaningowym. W ocenie perlaka w mikroskopie elektronowym skaningowym nie stwierdzono różnic w wyglądzie usuniętych komórek. Wniosek: leczenie operacyjne perlaka wymaga radykalnego usunięcia zmian i wskazań do operacji wywiadowczych, kontrolnych, jak u chorych dorosłych.

Słowa kluczowe: cholesteatoma $\bullet$ SEM

\section{XIII.3 • Rekonstrukcja anatomiczna i funkcjonalna po operacjach radykalnych zmodyfikowanych u dzieci}

\section{Anatomical and functional reconstruction after modified radical operation in children}

\author{
M. Mrówka ${ }^{1,2}$, M. Porowski ${ }^{1,2}$, \\ P. H. Skarżyński ${ }^{1,2,3,4}$, H. Skarżyński ${ }^{1,2}$ \\ ${ }^{1}$ Klinika Oto-Ryno-Laryngochirurgii Instytutu Fizjologii \\ i Patologii Stuchu, Warszawa/Kajetany \\ ${ }^{2}$ Światowe Centrum Stuchu IFPS $w$ Kajetanach \\ ${ }^{3}$ Zakład Niewydolności Serca i Rehabilitacji Kardiologicznej \\ Uniwersytetu Medycznego w Warszawie \\ ${ }^{4}$ Instytut Narządów Zmysłów, Kajetany
}

Cel pracy: Celem pracy jest analiza przypadków operacji rekonstrukcyjnych po wcześniejszych operacjach zmodyfikowanych u dzieci. Zasadniczym celem wykonania operacji radykalnej jest usunięcie ogniska infekcji $\mathrm{z}$ przestrzeni ucha środkowego i zapewnienie bezpieczeństwa choremu. Istotnym założeniem różnych modyfikacji tych zabiegów jest pozostawienie nawet niewielkich resztek aparatu przewodzącego ucha środkowego w taki sposób, by nie były one źródłem lub powodem nawrotów 
choroby, a jednocześnie pozwalały na efektywną rekonstrukcję w przyszłości. Można ją przeprowadzić jednoczasowo podczas operacji oczyszczającej lub w drugim etapie po wygojeniu jamy pooperacyjnej.

Material i metody: Analizę przeprowadzono w grupie 1576 uszu u pacjentów w wieku od 6 do 18 lat. Okres obserwacji wynosił minimum 3 lata. Wyniki oceniono po ok. 1 miesiącu, 3 miesiącach, 6 miesiącach, roku i 3 latach, zgodnie z przyjętym w Instytucie programem follow-up. Zakres operacji rekonstrukcyjnej obejmował wytworzenie części błony bębenkowej do poziomu kanału n. VII oraz - przy użyciu resztek materiałów autogennych i alloplastycznych, nowego aparatu przewodzeniowego ucha środkowego. Do rekonstrukcji błony używano fragmentu ochrzęstnej, chrząstki lub powięzi z mięśnia skroniowego czy okostnej.

Wyniki: Poczynione obserwacje potwierdzają, że nawet w przypadkach bardzo zaawansowanych w przebiegu przewlekłego zapalenia ucha środkowego z perlakiem, destrukcją kosteczek słuchowych i/lub kości skroniowej, ziarniną lub wszystkimi zmianami łącznie, możliwa jest późniejsza efektywna rekonstrukcja funkcjonalna, którą uzyskano w różnym stopniu, w $83,7 \%$ przypadków.

Wnioski: 1. Przeprowadzenie operacji radykalnej bez zamknięcia ujścia bębenkowego trąbki słuchowej nie oznacza utraty na zawsze możliwości poprawy wydolności słuchu pacjenta. 2. Uzyskanie socjalnej wydolności słuchu w tak licznej grupie zoperowanych dzieci pozwala traktować takie postępowanie jako $\mathrm{z}$ wyboru u chorych po wcześniejszych lub jednoczasowo wykonywanych operacjach radykalnych zmodyfikowanych uszu.

Słowa kluczowe: rekonstrukcja anatomiczna • operacje radykalne zmodyfikowane

\section{XIII.4 • Wyniki myringoplastyk w leczeniu centralnych perforacji i kieszeni retrakcyjnych u dzieci}

\section{Pediatric myringoplasty for retraction pockets and central perforations}

\section{E. Hassmann-Poznańska, B. Skotnicka, K. Trzpis}

Klinika Otolaryngologii Dziecięcej w Białymstoku

Cel pracy: Zarówno perforacje centralne (CP) błony bębenkowej, jak i kieszenie retrakcyjne (RP) są następstwem zapalenia ucha środkowego. Chociaż i w jednym, i drugim przypadku leczenie chirurgiczne polega na odtworzeniu błony bębenkowej, zabiegi różnią się materiałem użytym do przeszczepu. Celem pracy było ustalenie, czy wyniki myringoplastyk różnią się w zależności od wskazań do ich wykonania.

Materiał i metody: Przeprowadzono retrospektywną ocenę dokumentacji 99 (114 uszu) chorych (średni wiek $11,9 \pm 3,2$ lat), u których przeprowadzono myringoplastykę. Średni okres obserwacji wynosił 29 miesięcy. 67 uszu było operowanych $\mathrm{z}$ powodu $\mathrm{CP}, 47 \mathrm{z}$ powodu nieodprowadzalnych i niekontrolowalnych RP. Z oceny wyłączono zabiegi łączone $\mathrm{z}$ mastoidektomią lub ossikuloplastyką.

W ocenie pooperacyjnej analizowano: wynik anatomiczny (zamknięcie błony, retrakcje), wynik czynnościowy (PTA $0,5,1,2,4 \mathrm{kHz}$, średnia rezerwa) i utrzymywanie się lub nawroty stanów zapalnych ucha środkowego.

Wyniki: Obie badane grupy nie różniły się istotnie pod względem płci, wieku, słuchu przed zabiegiem czy okresu obserwacji pooperacyjnej. CP umiejscowione równie często w przednich, dolnych, jak i tylnych częściach błony bębenkowej, natomiast RP głównie w jej częściach tylno-górnych.

Aktywny stan zapalny był obecny w 17,9\% uszu operowanych $\mathrm{z}$ powodu CP. W uszach $\mathrm{z}$ RP był on istotnie częstszy - 42,5\% $(\mathrm{p}=0,004) \mathrm{z}$ powodu współistniejącego wysiękowego zapalenia ucha. Wyniki anatomiczne: niezamknięcie błony bębenkowej lub powtórne perforacje obserwowano w 9\% uszu z CP i 2,1\% uszu z RP. Niewielkie retrakcje błony bębenkowej obserwowano w 25,5\% uszu z PR i 16,4\% uszu z CP. Bardziej zaawansowane atelektazje i kieszenie retrakcyjne występowały w 7,5\% uszu z CP i 12,8\% uszu z RP. Różnice w wynikach anatomicznych pomiędzy obu grupami nie były istotne statystycznie $(\mathrm{p}=0,28)$. Wyniki czynnościowe były podobne w obu grupach (średnia redukcja rezerwy ślimakowej wynosiła 8,3 dB w grupie z RP i 7,4 dB w grupie z CP. Dobry wynik czynnościowy określany jako rezerwa.

Wnioski: Chociaż zarówno wyniki anatomiczne, jak i czynnościowe myringoplastyk u dzieci są zadowalające, zarówno w przypadkach CP jak i RP, to w tych ostatnich należy się liczyć z licznymi nawrotami wysiękowego zapalenia ucha.

Słowa kluczowe: myringoplastyki • kieszenie retrakcyjne - perforacja błony bębenkowej • dzieci

\section{XIII.5 - Algorytm postępowania w wadach wrodzonych ucha zewnętrznego i środkowego u dzieci}

\section{Mrówka ${ }^{1,2}$, H. Skarżyńskii,2}

\section{${ }^{1}$ Klinika Oto-Ryno-Laryngochirurgii Instytutu Fizjologii \\ i Patologii Stuchu, Warszawa/Kajetany \\ ${ }^{2}$ Światowe Centrum Stuchu IFPS $w$ Kajetanach}

Wada wodzona małżowiny usznej wraz z zazwyczaj towarzyszącą jej pierwotną atrezją przewodu słuchowego zewnętrznego i deformacją ucha środkowego stanowi złożony i wymagający kompleksowego postępowania problem funkcjonalny (upośledzenie słuchu) i estetyczny (brak lub deformacja małżowiny usznej). Tylko sama mikrocja występuje raz na około 20000 żywych urodzeń, drugie tyle to atrezja przewodu słuchowego zewnętrznego. Wady te są częstsze u płci męskiej 3: 2 i występują obustronnie w 25-30\% przypadków. Poza niedosłuchem przewodzeniowym, w $12-50 \%$ przypadków może towarzyszyć im różnego stopnia odbiorcze upośledzenie słuchu. 
Rozwój mikrochirurgicznych technik rekonstrukcyjnych, wprowadzenie do praktyki otolaryngologicznej metod osteointegracji oraz udoskonalenie aparatów słuchowych zakotwiczanych w kości skroniowej (BAHA, BAHA ATTRACT, PONTO, BONEBRIDGE, VIBRANT), zmieniły bardzo wiele $\mathrm{w}$ podejściu do problemu wad wrodzonych ucha zewnętrznego, zwiększając w istotny sposób zakres możliwości terapeutycznych i modyfikując wskazania. Wybór właściwego postępowania jest jednak bardzo trudny, czasochłonny i wymaga dużej wiedzy i doświadczenia od całego zespołu.

Autor przedstawia współczesne możliwości leczenia wad wrodzonych ucha środkowego i zewnętrznego, ze szczególnym uwzględnieniem kolejności podejmowanych działań, co zastanie ujęte w przejrzystej formie algorytmów postępowania.

\section{XIII.6 • Jak można bezpiecznie operować przetoki przeduszne u dzieci?}

\author{
K. Niemczyk, A. Bruzgielewicz, R. Bartoszewicz, \\ K. Morawski
}

Katedra i Klinika Otolaryngologii Uniwersytetu Medycznego $w$ Warszawie

Wstęp: Wady pierwszego łuku skrzelowego są rzadką patologią, występującą w około $8 \%$ wszystkich zaburzeń tego typu. Występują jako torbiele, zatoki lub przetoki, Zwykle położone są w bliskości lub łączą się z przewodem słuchowym zewnętrznym oraz mają różną topografię do gałązek nerwu twarzowego. Powodują nawracające stany zapalne. Leczone są zazwyczaj przez innych, niż laryngolodzy, specjalistów. Work w 1972 r. wyróżnił 2 typy przetok, w różnym stopniu powiązanych z przebiegiem nerwu twarzowego. Leczenie przetok jest zazwyczaj trudne ze względu na bliskość nerwu twarzowego, a jego stopień wzrasta z liczbą poprzednio wykonywanych zabiegów.

Materiał i metody: Autorzy analizują problemy diagnostyczne i terapeutyczne w grupie 15 pacjentów z przetokami przedusznymi typu I lub II, których leczenie rozpoczęło się w wieku dziecięcym. Szczególną uwagę przykładano do ustalenia wcześniejszego modelu postępowania zarówno zachowawczego, jak i chirurgicznego.

Wyniki: Stwierdzono, że badaniem najbardziej wiarygodnym do celów chirurgicznego leczenia był RM twarzoczaszki. Zakres leczenia chirurgicznego zależał od wcześniej wykonywanych zabiegów oraz kwalifikacji przetoki do I lub II typu w klasyfikacji Worka. Stopień trudności operacyjnej zależał od typu przetoki i liczby wcześniejszych interwencji. U 7 wcześniej operowanych pacjentów liczba interwencji wahała się od 1-8. Czas trwania leczenia wynosił od 6 miesięcy do 20 lat. W każdym przypadku przetoki grupy II lub nawrotów po wcześniejszych interwencjach wykonywano identyfikację nerwu twarzowego. Monitoring nerwu twarzowego stosowano tylko w 2 przypadkach, gdy wielokrotnie wcześniej lokalizowano nerw twarzowy. Nie stwierdzono pogorszenia czynności nerwu twarzowego w żadnym $\mathrm{z}$ operowanych przypadków.
Wnioski: Diagnostyka przedoperacyjna oparta o badanie RM pozwala na rozróżnienie przetok przedusznych I i II typu. Przetoki I typu mogą być operowane bez lokalizacji nerwu twarzowego. Przetoki II typu mogą być bezpiecznie operowane tylko po wypreparowaniu (lokalizacji nerwu twarzowego w przyusznicy). Monitorowanie nerwu twarzowego nie jest warunkiem lokalizacji nerwu twarzowego i nie powinno stanowić o odmowie podjęcia się leczenia chirurgicznego.

Słowa kluczowe: preauricular fistula $\bullet 1^{\text {st }}$ branchial cleft fistula • surgery

\section{XV.1 • Trudne przypadki onkologiczne w laryngologii dziecięcej}

\section{K. Niemczyk ${ }^{1}$, L. Zawadzka-Głos ${ }^{2}$}

\author{
${ }^{1}$ Katedra i Klinika Otolaryngologii Uniwersytetu Medycznego \\ $w$ Warszawie \\ ${ }^{2}$ Klinika Otolaryngologii Dziecięcej Uniwersytetu Medycznego \\ $w$ Warszawie
}

Wstęp: Guzy podstawy czaszki u dzieci stanowią różnorodną grupę patologii, której wspólnym wykładnikiem morfologicznym jest umiejscowienie na granicy z tkanką mózgową. Leczenie takich zmian wymaga doświadczenia chirurgicznego i zaplecza diagnostycznego, co możliwe jest w ośrodkach uniwersyteckich.

Materiał i metody: Autorzy przedstawiają przypadki różnych guzów (osłoniaków przedsionkowych jednostronnych i obustronnych, włókniaka kostniejącego podstawy przedniego dołu czaszki, włókniaka młodzieńczego, i rabdomyosarkomy dołu podskroniowego) leczonych operacyjnie lub będacych w obserwacji. Wszystkie przypadki operowano technikami minimalnie inwazyjnej chirurgii z zachowaniem funkcji neurologicznych.

Wyniki: Leczenie chirurgiczne nerwiaków pozwoliło zachować prawidłową czynność nerwu twarzowego we wszystkich przypadkach zarówno guzów jednostronnych, jak i obustronnych. Słuch został zachowany w ponad 50\% przypadków całej grupy osłoniaków. W przypadkach pozostałych typów guzów nie zanotowano istotnych komplikacji pooperacyjnych.

Wnioski: Leczenie guzów podstawy czaszki u dzieci pozwala na zachowanie czynności neurologicznych w zakresie miejsca operowanego niezależnie od patologii. Technika chirurgiczna podstawy czaszki u dzieci powinna być ograniczana do technik minimalnie inwazyjnych. Ze względu na małą liczbę patologii podstawy czaszki ich leczenie powinno odbywać się w ośrodkach mających odpowiednie doświadczenie.

Słowa kluczowe: skull base tumor in children • acoustic neuroma $\bullet$ Neurofibromatosis type 2 - ossificans $\bullet$ fibroma $\bullet$ angiofibroma juvenile 


\section{XV.2 • Mięsaki głowy i szyi u dzieci}

\section{J. Szydłowski}

Klinika Otolaryngologii Dziecięcej Katedry Otolaryngologii

i Onkologii Laryngologicznej Uniwersytetu Medycznego

w Poznaniu

Wstęp: Mięsaki są najczęstszymi nowotworami złośliwymi tkanek miękkich u dzieci. Blisko $40 \%$ wszystkich mięsaków tkanek miękkich w tej grupie wiekowej, zarówno RMS i non-RMS, stwierdza się w obrębie głowy i szyi. Najczęstszy z nich - rhabdomyosarcoma rozpoznawany jest w ponad połowie przypadków. Podział anatomiczny mięsaków w tej okolicy uwzględnia trzy główne grupy:

1. Występujące w obrębie oczodołu i powiek - nie naciekające kości.

2. Zlokalizowane okołooponowo (ucho środkowe, wyrostek sutkowaty kości skroniowej, jama nosowa, zatoki przynosowe, dół skrzydłowo-podniebienny).

3. Pozostałe lokalizacje.

Materiał i metody: W latach 2010-2014 Klinika Otolaryngologii Dziecięcej Katedry Otolaryngologii i Onkologii Laryngologicznej UM w Poznaniu współuczestniczyła $\mathrm{w}$ procesie diagnostyki i leczenia 15 chorych $\mathrm{z}$ mięsakami tkanek miękkich zlokalizowanymi w obrębie głowy i szyi. Zmiany obejmowały odpowiednio: dół skrzydłowo-podniebienny - 4 przypadki, oczodół i śliniankę przyuszną - po 3 przypadki, część nosową gardła, zatoki przynosowe - po 2 przypadki, wyrostek sutkowaty kości skroniowej - 1 przypadek.

Wyniki: W 11 przypadkach wykonano biopsje diagnostyczne guza. Zaledwie u 1 chorego możliwe okazało się przeprowadzenie pierwotnej resekcji guza R0, u dwóch R1. W jednym przypadku wykonano resekcję wtórną. W dwóch kolejnych przypadkach przeprowadzono radykalne zabiegi ratunkowe wobec odpowiednio 3 i 4 wznowy procesu rozrostowego.

Wnioski: Mięsaki tkanek miękkich głowy i szyi stanowią niezwykle trudny problem diagnostyczny. Gwałtowna dynamika wzrostu masy guza oraz zazwyczaj skąpoobjawowy przebieg początkowy procesu chorobowego sprawiają, iż w chwili rozpoznania przeprowadzenie pierwotnej resekcji guza jest najczęściej niemożliwe $\mathrm{z}$ uwagi na ich dalece okaleczający charakter. Duże nadzieje i jednocześnie obawy dotyczące leczenia złośliwych guzów głowy i szyi u dzieci pokłada się obecnie w rozwoju terapii protonowej.

Słowa kluczowe: mięsaki tkanek miękkich • głowa i szyja $\bullet$ dzieci

\section{XV.3 • Guz olbrzymiokomórkowy szczęki - trudności diagnostyczne i leczenie u dziecka 8-letniego}

\section{A. Zakrzewska, M. Kozakiewicz}

Klinika Otolaryngologii, Audiologii i Foniatrii Dziecięcej, Uniwersytecki Szpital Kliniczny nr 4 w Łodzi

Guzy szczęki, zarówno łagodne jak i złośliwe, należą do rzadkich nowotworów szczególnie u dzieci. Występują częściej u kobiet, głównie pomiędzy 2 a 4 dekadą życia. Jednym $\mathrm{z}$ rodzajów guzów szczęki jest guz olbrzymiokomórkowy (Central giant cell lesion). Wywodzi się on z komórek kości. Guz ten może mieć charakter miejscowo złośliwy prowadząc, poprzez szybki wzrost do zniszczenia struktur otaczających, w innych przypadkach może ulec zezłośliwieniu. Jedyną skuteczna metodą leczenia jest rozległa resekcja kości, w której się rozrasta. Zarówno chemio, jak i radioterapia są przeciwwskazane. W 50\% przypadków odnotowuje się wznowę po okresie ok. 2 lat od zabiegu. $\mathrm{W}$ diagnostyce różnicowej należy uwzględniać guz brunatny współistniejący z zaburzeniami funkcji przytarczyc.

Opis przypadku: Chłopiec 8-letni przyjęty do Kliniki $\mathrm{w}$ trybie pilnym $\mathrm{z}$ powodu zmiany na podniebieniu twardym od ok. 2 tygodni, szybko powiększającej się oraz zaburzeń mowy bez zaburzeń połykania. $Z$ wywiadu wiadomo, że przed 7 miesiącami miał usuniętą torbiel przyzębną. W trakcie diagnostyki dwukrotnie pobierano wycinki ze zmiany stwierdzając w badaniu histopatologicznym guz olbrzymiokomórkowy. Badania obrazowe CT oraz RM potwierdzały zmiany o charakterze rozrostowym dotyczące kości szczęki po stronie prawej obejmujące wyrostki zębowe oraz uniesienie dna jamy nosa w kierunku przewodu. Wykonano również badania USG węzłów chłonnych szyi, RTG klatki piersiowej i badania endokrynologiczne, określono poziom wapnia i parathormonu, w celu wykluczenia zaburzeń przytarczyc. Wobec jednoznacznego obrazu Central giant cell lesion wraz z cechami zezłośliwienia i konieczności rozważenia rozległej resekcji szczęki poszukiwano metod alternatywnych. Po uzgodnieniu planu operacyjnego z chirurgiem szczękowo-twarzowym podjęto decyzję o głębokiej resekcji centrum guza połączonej z elektrokoagulacją loży kostnej. Metoda ta została przedstawiona przez prof. A. R. Salama z University of Maryland Medical Center U. S. w 2014 roku w celu zaopatrzenia nowotworów szczęki miejscowo złośliwych (mucoepidermoid). 
XV.4 • Przypadek wyleczonego raka płaskonabłonkowego ucha środkowego u małego dziecka

\section{Squamous cell carcinoma in the middle ear - a case report}

\section{J. Gawlik' ${ }^{1}$ R. Gawlik², J. Składzieńn ${ }^{2}$}

${ }^{1}$ Katedra i Klinika Otolaryngologii Collegium Medicum Uniwersytetu Jagiellońskiego w Krakowie

${ }^{2}$ Koło Naukowe przy Katedrze i Klinice Otolaryngologii Collegium Medicum Uniwersytetu Jagiellońskiego w Krakowie; obecnie Instytut „Centrum Zdrowia Matki Polki” w Łodzi

Matka w czasie ciąży zapadła na raka macicy. Dlatego w 6 miesiącu ciąży wykonano cięcie cesarskie. Dziecko przeżyło i w drugim roku życia zgłosiło się do Kliniki ORL UJ z powodu objawów przewlekłego zapalenia ucha $\mathrm{z}$ niewydolnością $\mathrm{n}$. VII. Wykonano operację $\mathrm{z}$ usunięciem zmian. W usuniętym materiale znaleziono raka płaskonabłonkowego G-2.

Po zabiegu dziecko radykalnie leczone napromienianiem. Po 3 latach kolejna reoperacja zmian, a ostatnia w celu zamknięcia ucha w 8 miesięcy później.

Obecnie dziecko w wieku 8 lat bez objawów nowotwo$\mathrm{ru}$, prawidłowo rozwijające się, z niewielkim niedowładem dolnej gałązki n. VII i głuchym uchem w stałej kontroli tutejszej kliniki.

Słowa kluczowe: rak płaskonabłonkowy ucha

\section{XV.5 • Nowotwory złośliwe zatok przynosowych u dzieci}

\section{Malignant neoplasms of paranasal sinuses in children}

\section{Dębska, M. Frąckiewicz, L. Zawadzka-Głos}

Klinika Otolaryngologii Dziecięcej, Samodzielny Publiczny Dziecięcy Szpital Kliniczny w Warszawie

Cel pracy: Analiza przypadków nowotworów złośliwych zatok przynosowych u dzieci.

Materiał i metody: Badaniem objęto dzieci hospitalizowane w Samodzielnym Publicznym Dziecięcym Szpitalu Klinicznym w Warszawie $\mathrm{z}$ rozpoznanym nowotworem złośliwym zatok przynosowych w latach 2007-2014. Badanie miało charakter retrospektywny.

Wyniki: W badanym okresie nowotwór złośliwy zatok przynosowych rozpoznano u sześciorga dzieci. W badanej grupie były 3 dziewczynki i 3 chłopców, w wieku od 10 miesięcy do 16 lat. Rozpoznano 2 przypadki chłoniaków typu Burkitta u 7-letniej dziewczynki i 5-letniego chłopca, 1 przypadek raka płaskonabłonkowego u 16-letniego chłopca, 1 przypadek chłoniaka limfoblastycznego u 8-letniej dziewczynki, 1 przypadek neuroblastoma u 10-miesięcznej dziewczynki oraz 1 przypadek rabdomyosarcoma embryonale u 4,5-letniego chłopca.

Wnioski: 1. U dzieci nowotwory złośliwe głowy i szyi występują rzadko. 2. W tej grupie wiekowej najczęstsze są nowotwory nienabłonkowe, takie jak chłoniaki, mięsaki, nowotwory pochodzenia neuroektodermalnego. 3 . $\mathrm{W}$ badanej grupie najczęstszym nowotworem był chłoniak nieziarniczy typu Burkitta. 4. Wczesne objawy nowotworów mogą sugerować przewlekły stan zapalny nosa i zatok przynosowych.

Słowa kluczowe: nowotwory złośliwe • zatoki przynosowe obrzęk twarzy

\section{XV.6 Ocena występowania guzów złośliwych głowy i szyi u dzieci}

\section{Epidemiology of the children head and neck malignant tumours}

\section{T. Horoch, G. Mielnik-Niedzielska}

Klinika Otolaryngologii Dziecięcej, Foniatrii i Audiologii Uniwersytetu Medycznego w Lublinie

Cel pracy: Celem pracy jest przedstawienie występowania guzów złośliwych głowy i szyi u dzieci. Celem pobocznym jest określenie danych epidemiologicznych tego zjawiska.

Materiał i metody: Badaniem retrospektywnym objęto pacjentów Kliniki Otolaryngologii Dziecięcej Uniwersytetu Medycznego w Lublinie w latach 2004-2015.

Wyniki: Nowotwory złośliwe rozpoznano u 15 pacjentów, w tym 8 dzieci było płci męskiej i 7 płci żeńskiej. Średni wiek pacjentów wynosił 8 lat. Najczęstszym nowotworem był rabdomyosarcoma embroynale, w dalszej kolejności chłoniak Burkitta, opisano także jeden przypadek guza Ewinga. Zmiany były najczęściej zlokalizowane w policzku, rzadziej dotyczyły migdałów podniebiennych i jamy nosowej.

Wnioski: W przypadku lokalizacji okołooponowej (tj. jama nosa, zatoki, ucho środkowe) u około jednej trzeciej pacjentów dochodzi do zajęcia OUN. W naszym materiale nie obserwowaliśmy takich objawów, a zmiany manifestowały się najczęściej w postaci zmiany o charakterze mniej lub bardziej wyczuwalnego guza. W związku z tym nawet w sytuacjach o łagodnym przebiegu możemy mieć do czynienia ze zmianą o złośliwym charakterze. Dlatego w takich przypadkach należy zachować szczególną uwagę.

Słowa kluczowe: guzy złośliwe • rabdomyosarcoma embryonale $\bullet$ chłoniaki $\bullet$ białaczki $\bullet$ przerzuty 


\section{XV.7 Guzy w okolicy przyuszniczo- żwaczowej leczone operacyjnie w Klinice Otolaryngologii, Audiologii i Foniatrii Dziecięcej Uniwersytetu Medycznego w Lodzi w latach 2011-2014}

\section{Tumors in parotidomasseteric region in children treated with surgery in Department of Pediatric Otorhinolaryngology, Audiology and Phoniatry, Medical University of Lodz in 2011-2014}

\section{R. Zieliński, A. Zakrzewska}

Klinika Otolaryngologii, Audiologii i Foniatrii Dziecięcej Uniwersytetu Medycznego w Łodzi

Cel pracy: Celem pracy jest przedstawienie postępowania diagnostycznego i operacyjnego przeprowadzonego $\mathrm{u}$ dzieci leczonych $\mathrm{z}$ powodu guzów w okolicy przyuszniczo-żwaczowej w Klinice Otolaryngologii, Audiologii i Foniatrii Dziecięcej Uniwersytetu Medycznego w Łodzi.

Materiał i metody: Analizowany materiał dotyczy 7 dzieci leczonych w Klinice Otolaryngologii, Audiologii i Foniatrii Dziecięcej Uniwersytetu Medycznego w Łodzi w latach 2011-2014. Oceniano podstawowe dane osobowe, wywiad, w którym uwzględniono czas trwania choroby, elementy badania przedmiotowego, wyniki badań obrazowych i dodatkowych przed podjęciem leczenia, leczenie operacyjne, wyniki badania histopatologicznego materiału operacyjnego oraz follow-up.

Wyniki: U wszystkich pacjentów wykonano ocenę ultrasonograficzną okolicy stwierdzonej zmiany. Ze względu na wątpliwości diagnostyczne u 5 wykonano badanie rezonansu magnetycznego, a u 2 badanie tomografii komputerowej. U 6 wykonano biopsję aspiracyjną cienkoigłowa pod kontrolą ultrasonorafii, której wynik w badaniu cytopatologicznym tylko u dwojga był zgodny $\mathrm{z}$ rozpoznaniem histopatologicznym usuniętej operacyjnie zmiany. Do guzów stwierdzonych w okolicy przyuszniczo-żwaczowej $\mathrm{u}$ dzieci należały gruczolaki wielopostaciowe, rak śluzowo-naskórkowy, fibromatoza, gruczolak podstawnokomórkowy, nerwiak osłonkowy oraz malformacja naczyniowa.

Wykonana operacja pozwoliła na całkowite usunięcie zmiany u 6 dzieci. U żadnego dziecka nie wystąpiły objawy niedowładu lub porażenia gałęzi nerwu twarzowego w okresie pooperacyjnym. W okresie rocznej obserwacji, w kontrolnych badaniach ultrasonograficznych, nie stwierdzono wznowy guza u 6 dzieci. U dziecka z malformacją naczyniową, u którego doszczętność usunięcia zmiany nie była w pełni możliwa, nie obserwowano wzrostu resztki guza w kontrolnych badaniach ultrasonograficznych w okresie ponad roku po operacji.

Wnioski: 1. Wszystkie przypadki guzów w okolicy przyuszniczo-żwaczowej u dzieci wymagają dokładnego badania podmiotowego, przedmiotowego oraz badania ultrasonograficznego uzupełnionego w razie konieczności diagnostyką obrazową RM lub TK. 2. Biopsja aspiracyjna cienkoigłowa zmiany pod kontrolą ultrasonograficzną nie jest badaniem rozstrzygającym o rozpoznaniu guza w okolicy przyuszniczo-żwaczowej u dzieci. 3. Rozległość planowanego zabiegu zależy od szczegółowej oceny wszystkich uzyskanych informacji i wyników badań w okresie przedoperacyjnym.

Słowa kluczowe: dzieci • okolica przyuszniczo-żwaczowa $\bullet$ guzy

\section{XV.8 Prezentacja laryngologiczna schorzeń onkologicznych u dzieci na podstawie obserwacji własnych}

\section{ENT presentation of oncological diseases in children based on their own observations}

\author{
G. Sobol, M. Cofała, M. Dec, I. Bielecki, \\ T. Wolan
}

Oddział Laryngologii, Górnośląskie Centrum Zdrowia Dziecka Ślaskiego Uniwersytetu Medycznego w Katowicach

Cel pracy: Nowotwory wieku dziecięcego stanowią ok. $1 \%$ wszystkich rozpoznań onkologicznych i w porównaniu do występujących w populacji dorosłych wykazują bardzo duże zróżnicowanie histopatologiczne oraz umiejscowienie anatomiczne. Najczęściej u dzieci rozpoznawane są białaczki, które wraz z chłoniakami stanowią blisko $50 \%$ wszystkich rozpoznań onkologicznych. Najrzadziej, poniżej $1 \%$, w populacji dziecięcej występują raki. Wśród specjalistów, do których w początkowym okresie choroby trafia dziecko onkologiczne, są laryngolodzy. Analiza objawów klinicznych u dzieci skierowanych do oddziału laryngologii, u których ostatecznie postawiono rozpoznanie onkologiczne, w celu określenia tak zwanych masek laryngologicznych nowotworów dziecięcych.

Materiał i metody: Badaniem objęto 15 dzieci z objawami schorzeń laryngologicznych, u których ostatecznie postawiono diagnozę onkologiczną. Poddano analizie objawy kliniczne, czas obserwacji i ostateczne rozpoznanie. Wiek pacjentów wynosił od 1 roku do 16 lat.

Wyniki: Najczęstszymi objawami stanowiącymi podstawę skierowania do laryngologa były: limfadenopatia szyjna nie reagująca na antybiotykoterapię, $\mathrm{w}$ tym podejrzenie ropnia $(n=7)$; uporczywe krwawienia $\mathrm{z}$ nosa $(\mathrm{n}=6)$; uczucie niedrożności nosa; trudności w połykaniu; podejrzenie przerostu migdałka gardłowego $(n=2)$; angina oporna na leczenie; podejrzenie ropnia okołomigdałkowego $(n=1)$; wytrzeszcz gałki ocznej; podejrzenie ropnia oczodołu $(n=2)$. Czas obserwacji pacjentów przed postawieniem diagnozy nowotworu wynosił od 5 do 32 dni. Ostateczne rozpoznania były nastepujące: ostra białaczka $(n=3)$; rak nosogardła $(n=3)$; neuroblastoma $(n=3)$; chłoniak złośliwy $(\mathrm{n}=2)$; mięsak prążkowanokomórkowy $(\mathrm{n}=2)$; histiocytoza komórek Langerhansa $(\mathrm{n}=1)$; czerniak złośliwy $(\mathrm{n}=1)$. Wszyscy pacjenci zostali objęci opieką onkologiczną.

Wnioski: Nawrotowe krwawienie z nosa, niepoddająca się leczeniu limfadenopatia szyjna i podżuchwowa, trudności w połykaniu, zaburzona drożność nosa, wytrzeszcz gałki 
ocznej są objawami mogącymi stanowić prezentację tzw. maski schorzenia nowotworowego. Laryngolog w przypadku wystąpienia powyższych objawów powinien zachować czujność onkologiczną.

Słowa kluczowe: nowotwory • głowa i szyja • dzieci • objawy laryngologiczne

\section{XV.9 • Nerwiak nerwu błędnego jako problem diagnostyczny $i$ terapeutyczny}

\section{Cervical vagal schwannoma as diagnostic and therapeutic problem}

\section{J. Mierzwiński, M. Muller}

Oddziat Otolaryngologii, Audiologii i Foniatrii Dziecięcej,

Wojewódzki Szpital Dziecięcy w Bydgoszczy

$\mathrm{Na}$ podstawie przypadku nerwiaka nerwu błędnego u 13-letniej dziewczynki i dostępnych w literaturze danych przeanalizowano czynniki mogące wpłynąć na wczesne rozpoznanie guza oraz badania konieczne dla potwierdzenia diagnozy. Przeprowadzono również przegląd możliwości terapeutycznych, z położeniem szczególnego nacisku na jak najbardziej zachowawczy wybór chirurgicznego dostępu do nerwiaka u pacjenta w wieku rozwojowym $\mathrm{z}$ uwzględnieniem nowych technik umożliwiających zmniejszenie objętości guza. Przedstawiono możliwe powikłania i zagrożenia zarówno podczas procesu leczenia, jak i w okresie rekonwalescencji.

\section{XVII.P.1 • Porównanie skuteczności leczenia glikokortykosteroidami w podgłośniowym zapaleniu krtani u dzieci}

\section{Comparison of glucocorticoids treatment efficacy in treating croup in children}

\section{S. Kedzierawska, A. Al Jazani, G. Mielnik-Niedzielska}

Klinika Otolaryngologii Dziecięcej, Foniatrii i Audiologii w Lublinie

Cel pracy: Zapalenie krtani w 80\% jest infekcją wirusową, spowodowaną głównie przez wirusy paragrypy. Celem leczenia jest utrzymanie prawidłowej drożności drogi oddechowej. Metodą z wyboru wydaje się być leczenie kortykosteroidami. Celem pracy była ocena skuteczności leczenia glikokortykosteroidami w krupie wirusowym.

Materiał i metody: Wykonano retrospektywną analizę historii chorób pacjentów hospitalizowanych w Klinice Otolaryngologii Dziecięcej, Foniatrii i Audiologii w latach 2010-2014 z powodu podgłośniowego zapalenia krtani. U wszystkich pacjentów zastosowano budezonid $250 \mu \mathrm{g}$ $\mathrm{w}$ inhalacji co $8 \mathrm{~h}$ lub co $12 \mathrm{~h}$. W postaciach ciężkich zastosowano hydrokortyzon w dawce $10 \mathrm{mg} / \mathrm{kg}$ jednorazowo. Poddano analizie czynniki wymagające uzupełnienia leczenia wziewnego steroidoterapią systemową lub podaniem epinefryny w nebulizacji.

Wyniki: Przeanalizowano 500 historii chorób pacjentów z postacią lekką, średniociężką i ciężką podgłośniowego zapalenia krtani. Średnia wieku pacjentów wynosiła 3,3 lat. W badanej grupie chłopcy stanowili $62,2 \%$ a dziewczynki 34,7\%. Objawami występującymi najczęściej były: suchy, szczekający kaszel i duszność wdechowo-wydechowa. Zastosowanie budezonidu w nebulizacji spowodowało ustąpienie objawów u większości pacjentów w 24 $\mathrm{h}$ po przyjęciu do szpitala. Wśród czynników predysponujących do postaci ciężkiej krupu wirusowego najczęściej w wywiadzie pojawiały się: zapalenia krtani w przeszłości, zapalenia oskrzeli i płuc, częste infekcje górnych dróg oddechowych.

Wnioski: Leczenie glikokortykosteroidami wziewnymi jest skuteczne w postaci lekkiej i średniociężkiej podgłośniowego zapalenia krtani, natomiast w postaciach ciężkich leczenie wymaga uzupełnienia terapii o glikokortykosterydy podane systemowo i ewentualnie epinefrynę w nebulizacji.

Słowa kluczowe: podgłośniowe zapalenie krtani • glikokortykosteroidy $\bullet$ krup wirusowy

\section{XVII.P.2 • Ocena wartości osobistych dzieci Z wadą słuchu ${ }^{\star}$}

\section{Evaluation of personal values by children with hearing loss}

\section{A. Frankowska, M. D. Głowacka}

Katedra i Zakład Organizacji i Zarządzania w Opiece Zdrowotnej, Wydział Nauk o Zdrowiu Uniwersytetu Medycznego w Poznaniu

Cel pracy: Celem pracy jest identyfikacja i ocena symboli szczęścia osobistego oraz ważnych wartości osobistych, które są istotne $\mathrm{w}$ życiu dzieci $\mathrm{z}$ różnymi stopniami ubytku słuchu i mają wpływ na ich jakość życia.

Materiał i metody: Materiał badawczy stanowiło 122 dzieci w wieku 8 do 18 lat, w tym 63 dziewczęta i 59 chłopców. Analizy dokonano w 4 grupach niedosłuchów (A - lekki, B - umiarkowany, C - znaczny, D - głęboki) oraz w 3 grupach wiekowych (8-12 lat, 13-16 lat, powyżej 16 lat). Do analizy wyników wykorzystano kwestionariusz LWO (Lista Wartości Osobistych według Z. Juczyńskiego), który składał się z 2 części. Pierwsza zawierała 9 symboli (wyznaczników) szczęścia, druga zawierała 10 kategorii wartości osobistych. Ocenianymi symbolami szczęścia były: „duży krąg przyjaciół”, „udane życie rodzinne”, „wykonywanie ulubionej pracy (czynności)”, „sukcesy w nauce”, „dobre zdrowie”, „bycie potrzebnym dla innych”, „dobre warunki materialne”, „życie pełne przygód”, „sława, popularność”. Wybieranymi przez dzieci według ważności wartościami osobistymi były: „miłość, przyjaźń”, „dobre zdrowie, sprawność fizyczna, psychiczna”, „poczucie humoru, dowcip”, „inteligencja, bystrość umysłu”, „wiedza, mądrość”, „radość, zadowolenie”, „odwaga, stanowczość”, 
„dobroć, delikatność”, „ładny wygląd, prezencja”, „bogactwo, majątek".

Wyniki: Analiza wyników wykazała, że najwyższe oceny wśród symboli szczęścia w odpowiedziach dzieci z różnymi stopniami niedosłuchu otrzymały w kolejności: „dobre zdrowie”, „udane życie rodzinne” „sukcesy w nauce”, „duży krąg przyjaciół”. Najmniej utożsamiana ze szczęściem jest „sława i popularność". W grupach wiekowych dzieci i młodzieży niedosłyszących „dobre zdrowie” jest jednym z najważniejszych symboli szczęścia. Kolejność pozostałych symboli jest różna w poszczególnych przedziałach wieku. We wszystkich grupach niedosłuchów od lekkich do głębokich symbol szczęścia, jakim jest „dobre zdrowie” plasuje się na pierwszym miejscu, co świadczy o jego istotności w życiu badanych. Dzieci w całej grupie badanych niedosłuchów jako najważniejsze wartości osobiste, które są dla nich ważne w życiu, wskazują kolejno: "dobre zdrowie, sprawność fizyczną”, „wiedzę i mądrość” oraz „miłość, przyjaźń”, a najmniej ważne „ładny wygląd, prezencję” oraz „bogactwo i majątek”. W grupach wiekowych wybory wartości życiowych są różne. Jako najistotniejsza wartość osobista dla grupy dzieci z niedosłuchami lekkimi (A) wymieniane są „miłość i przyjaźń”, a dopiero na drugim miejscu "dobre zdrowie”. Natomiast w niedosłuchach $\mathrm{B}, \mathrm{C}$ i D na pierwszym miejscu jest „dobre zdrowie”, a „miłość i przyjaźń” plasują się na dalszej pozycji (np. piąte miejsce w niedosłuchach głębokich - D).

Wnioski: Dla dzieci z wadą słuchu istotne jest dobre zdrowie zarówno w kontekście symboli szczęścia, jak i wyznawanych wartości osobistych. Mniej istotne są wartości materialne. Im głębszy niedosłuch, tym istotniejszą wartością życiową jest dla tych dzieci „dobre zdrowie, sprawność fizyczna”. Relacje społeczne schodza na dalszy plan w odpowiedziach dzieci z niedosłuchami głębokimi.

Słowa kluczowe: dzieci niedosłyszące • symbole szczęścia - wartości osobiste

* Projekt zostat sfinansowany ze środków Narodowego Centrum Nauki nr N N404069140

\section{XVII.P.3 • Rola diagnozy psychologicznej w terapii SPS-S (Stymulacja Percepcji Sensorycznej - metoda Skarżyńskiego)}

\section{The role of psychological diagnosis in Stimulation of Sensory Perception - Skarżyński's Method}

D. Grudzień ${ }^{1}$, A. Skoczylas ${ }^{1}$, N. Czajka ${ }^{1}$, P. H. Skarżyński ${ }^{1,2,3}$, M. Kurkowski ${ }^{1}$, H. Skarżyński ${ }^{1}$

\footnotetext{
${ }^{1}$ Instytut Fizjologii i Patologii Stuchu, Warszawa/Kajetany

${ }^{2}$ Zakład Niewydolności Serca i Rehabilitacji Kardiologicznej Uniwersytetu Medycznego w Warszawie

${ }^{3}$ Instytut Narząów Zmysłów, Kajetany
}

Cel pracy: Celem niniejszej prezentacji jest przedstawienie roli diagnozy psychologicznej w terapii SPS-S.
Materiał i metody: Prezentacja dotyczy prawidłowo słyszących pacjentów, u których istnieje podejrzenie występowania zaburzeń przetwarzania słuchowego. Podczas diagnozy psycholog prowadzi badanie funkcji poznawczych, pogłębiony wywiad $\mathrm{z}$ rodzicami pacjenta oraz dzieckiem.

Wyniki: Nie u wszystkich pacjentów, u których występują trudności z funkcjonowaniem słuchowym, można stwierdzić zaburzenia przetwarzania słuchowego i zakwalifikować na terapię SPS-S ze względu na nieprawidłowy rozwój poznawczy lub problemy $z$ funkcjonowaniem emocjonalnym w określonym środowisku rodzinnym.

Wnioski: Psycholog jest niezbędnym specjalistą w procesie diagnozowania zaburzeń przetwarzania słuchowego i kwalifikowania do terapii SPS-S.

Słowa kluczowe: zaburzenia przetwarzania słuchowego • funkcjonowanie poznawcze $\bullet$ funkcjonowanie emocjonalne

\section{XVII.P.4 • Związek pomiędzy artykulacją głosek dentalizowanych a wybranymi testami APD na podstawie badań dzieci poddawanych terapii Stymulacji Percepcji Sensorycznej metodą Skarżyńskiego. Badanie pilotażowe}

The relationship between selected APD tests and articulation of fricative and affricative consonants in children undergoing Stimulation of Sensory Perception - Skarżyński’s Method. Pilot study

\section{A. Skoczylas ${ }^{1,2}$, A. Piłka ${ }^{1,2}$, Z. M. Kurkowski ${ }^{1,2}$,} D. Grudzieńn ${ }^{1,2}$, N. Czajka ${ }^{1,2}$

\footnotetext{
${ }^{1}$ Instytut Fizjologii i Patologii Stuchu, Warszawa/Kajetany

${ }^{2}$ Światowe Centrum Stuchu IFPS $w$ Kajetanach
}

Cel pracy: Celem niniejszej pracy było sprawdzenie, czy istnieje związek pomiędzy nieprawidłową realizacją głosek dentalizowanych (s, z, c, dz, sz, ż, cz, dż, ś, ź, ć, dź) a zaburzeniami przetwarzania słuchowego.

Materiał i metody: Grupę badaną stanowiły prawidłowo słyszące dzieci siedmio- i ośmioletnie, z zaburzeniami przetwarzania słuchowego i nieprawidłową realizacją głosek dentalizowanych, bez innych zaburzeń towarzyszących. Pacjenci z grupy objętej badaniem wykonali testy $\mathrm{z}$ baterii APD: DPT, FPT, DDT w wersji z ukierunkowaniem uwagi, GDT, DLF (dla dwóch tonów), DLFex (dla jednego tonu), a także „100-wyrazowy Test Artykulacyjny” E. Krajny. Następnie dzieci przeszły Stymulację Percepcji Sensorycznej metodą Skarżyńskiego, po czym powtórzono badania, a uzyskany materiał badawczy poddano analizie.

Wyniki: Badania FPT, DPT, „100-wyrazowy Test Artykulacyjny", DDT dla uwagi ukierunkowanej w lewo po terapii uległy istotnej statystycznie poprawie. Wyniki testów GDT oraz DLF dla jednego i dwóch dźwięków nie zmieniły się po terapii. Zaobserwowano również korelację wyników 
testu DDT ukierunkowanego do ucha lewego oraz z testu DLF dla jednego dźwięku w porównaniu z badaniem realizacji głosek dentalizowanych.

Wnioski: Dwa spośród testów przetwarzania słuchowego korelują $\mathrm{z}$ badaniami artykulacji głosek dentalizowanych i mogą być stosowane jako predyktor postępów w zakresie wymowy. Należy powtórzyć badanie korelacji testu FPT oraz realizacji głosek dentalizowanych na większej grupie badanych.

Słowa kluczowe: zaburzenia przetwarzania słuchowego - przetwarzanie słuchowe • APD • CAPD • artykulacja - głoski dentalizowane • głoski szumiące • głoski syczące • głoski ciszące

\section{XVII.P.5 • Problemy emocjonalno- społeczne u dzieci zaburzeniami przetwarzania słuchowego. Propozycje terapeutyczne}

\section{Socio-emotional and behavioral problems in children with Auditory Processing Disorders}

\section{J. Rostkowska ${ }^{1,2}$, J. Kobosko ${ }^{1,2}$, A. Geremek-Samsonowicz ${ }^{1,2}$ \\ ${ }^{1}$ Klinika Rehabilitacji Instytutu Fizjologii i Patologii Stuchu, Warszawa/Kajetany \\ ${ }^{2}$ Swiatowe Centrum Stuchu IFPS w Kajetanach}

Cel pracy: Celem badań była ocena zdrowia psychicznego dzieci z APD rozumianego jako trudności emocjonalne, społeczne oraz problemy przejawiające się w zachowaniu.

Materiał i metody: Badaniami objęto grupę 74 pacjentów ze zdiagnozowanymi zaburzeniami przetwarzania słuchowego. Grupę kontrolną stanowiło 75 dzieci ze szkół warszawskich. Do badań zastosowano Kwestionariusz Mocnych Stron i Trudności (SDQ) oraz ankietę - oba narzędzia wypełniane przez rodziców.

Wyniki: Okazało się, że dzieci z APD manifestują znacząco więcej problemów ze zdrowiem psychicznym ogółem, tj. występują one 3,8 razy częściej niż w grupie dzieci o typowym rozwoju z populacji ogólnej. Dzieci z APD przejawiają więcej problemów w sferze emocjonalnej, nadaktywności i koncentracji uwagi oraz kontaktów $\mathrm{z}$ rówieśnikami w porównaniu $\mathrm{z}$ dziećmi o typowym rozwoju.

Wnioski: Wyniki badań wskazują na konieczność włączenia w proces terapeutyczny grupowej lub indywidualnej terapii psychologicznej, treningu umiejętności komunikacyjnych, socjoterapii.

Słowa kluczowe: problemy emocjonalno-społeczne • APD - psychoterapia • socjoterapia
XVII.P.6 - Kamienie uszne w wysiękowym zapaleniu ucha środkowego

Ear stones in the otitis media with effusion

A. Wiatr, P. Muszyński, M. Wiatr, M. Ziąbka, R. Przeklasa, A. Wróbel, J. Składzień

Katedra i Klinika Otolaryngologii Collegium Medicum Uniwersytetu Jagiellońskiego $w$ Krakowie

Cel pracy: Analiza spektralna kamieni usznych uzyskanych w trakcje zabiegów kofochirurgicznych.

Materiał i metody: Materiał w postaci kamieni uzyskany w trakcie operacji kofochirurgicznych w obrębie ucha środkowego. Analiza za pomocą elektronowego mikroskopu skaningowego Nova NANOSEM 200 wraz z przystawką do analizy chemicznej w mikroobszarach EDS. Pomiar prowadzono przy użyciu detektora niskiej próżni (LVD), przy napięciu przyspieszającym wynoszącym $15 \mathrm{kV} \mathrm{i} 10 \mathrm{kV}$ oraz wielkości spotu równej 4 i 3,5. Obserwacje przeprowadzono w systemie detekcji elektronów wtórnych (SE).

Wyniki: Analiza chemiczna pokazała pojawienie się znacznej ilości pierwiastków: węgla, tlenu, potasu i wapnia, a także niewielkie ilości sodu i magnezu. Na podstawie wykonanej analizy ilościowej, uwzględniając wszystkie pierwiastki, stosunek molowy wapnia do fosforu wyniósł 1,23.

Wnioski: Badany materiał reprezentował związek fosforanu wapnia $\mathrm{z}$ układu CaO-P2O5-H20.

Słowa kluczowe: kamienie uszne • operacje kofochirurgiczne • wysiękowe zapalenie ucha środkowego

\section{XVII.P.7 • Perlaki wrodzone u dzieci - wczesne rozpoznanie, leczenie chirurgiczne i opieka pooperacyjna}

\section{Congenital cholesteatoma in children - early identification, surgical treatment and postoperative care}

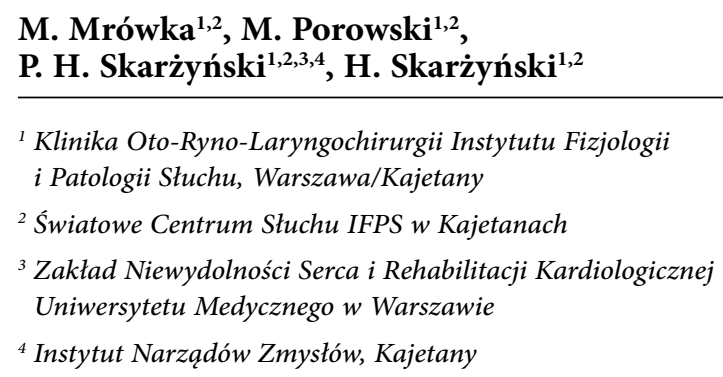

Cel pracy: Celem niniejszej pracy jest ocena wyników operacyjnego leczenia perlaków wrodzonych u dzieci oraz możliwości wczesnego wykrywania tego schorzenia. Analizowano również częstotliwość wznów perlaka oraz czynników, które mogą mieć z tym związek. 
Materiał i metody: Perlaki wrodzone są stosunkowo rzadkim schorzeniem występującym zwłaszcza u dzieci. Nierozpoznane wcześnie mogą spowodować duże zniszczenia elementów ucha środkowego, czasami wewnętrznego, prowadząc do upośledzenia słuchu czy innych powikłań. Spośród wielu tysięcy operacji uszu wykonywanych rocznie w naszej klinice, wyodrębniono grupę 49 pacjentów $\mathrm{w}$ wieku od 2 do 18 lat $\mathrm{z}$ rozpoznanym perlakiem wrodzonym, u których okres obserwacji wynosił minimum 3 lata. Pacjentów podzielono na dwie grupy: w grupie A byli najmłodsi pacjenci, u których możliwe do wykonania były tylko obiektywne badania słuchu, a w mniej licznej grupie $\mathrm{B}$ starsze dzieci, którym mogliśmy wykonać również badania subiektywne. Większość dzieci operowana była wyłącznie z dojścia przez przewód słuchowy zewnętrzny, inne $\mathrm{z}$ dojścia podwójnego. Rezultaty pooperacyjne były oceniane standardowo po 1, 6, 12 i 36 miesiącach.

Wyniki: Wyleczenie, rozumiane jako usunięcie zmian perlakowych, uzyskano u wszystkich pacjentów, jednakże by to osiągnąć niekiedy potrzebowano więcej niż jednego zabiegu operacyjnego. Zauważalną poprawę słuchu uzyskano u większości dzieci, u których rekonstruowano aparat przewodzący. U pacjentów $\mathrm{z}$ grupy $\mathrm{B}$ zamknięcie rezerwy ślimakowej do 10 dB uzyskano w 94,8\% przypadków.

Wnioski: W przypadku perlaków wrodzonych sukces operacji i wyniki pooperacyjne zależą przede wszystkim od wczesnego rozpoznania. W tych przypadkach uzyskujemy bardzo dobre rezultaty (usunięcie perlaka jest stosunkowo łatwe, a aparat ucha środkowego przewodzący dźwięki - niezniszczony). Wszystkie dzieci, u których przeprowadzono operację usunięcia perlaka wrodzonego, muszą być monitorowane (wnikliwa wideo- i mikrootoskopia, operacje „second look”, HRCT), ponieważ pomimo doskonałych narzędzi oraz postępu chirurgii możliwa jest niekontrolowana wznowa perlaka.

Słowa kluczowe: perlak • leczenie chirurgiczne • wczesne rozpoznanie

\section{XVII.P.8 • Zastosowanie audiometrii wysokoczęstotliwościowej i otoemisji akustycznych DPOAE do oceny ototoksyczności leczenia przeciwnowotworowego}

\section{The use of high frequency pure tone audiometry (HF-PTA) and distortion product otoacoustic emissions (DPOAEs) for evaluation the ototoxicity of anticancer therapy}

\section{B. Polski, J. Sroczyński, B. Pucher, M. Kotowski, J. Szydłowski}

Klinika Otolaryngologii Dziecięcej Uniwersytetu Medycznego w Poznaniu

Cel pracy: Proces leczenia przeciwnowotworowego u dzieci wiąże się niejednokrotnie z koniecznością zastosowania pochodnych platyny, które w swoim ubocznym działaniu mogą prowadzić do nabytych odbiorczych niedosłuchów o charakterze wysokoczęstotliwościowym. Monitorowanie tego zjawiska przy użyciu audiometrii wysokoczęstotliwościowej i otoemisji akustycznych produktu zniekształceń nieliniowych ślimaka pozwala na wykrycie pierwszych symptomów niedosłuchu, nawet gdy nie jest on odczuwalny dla pacjenta i nie wpływa na zdolności rozumienia mowy.

Materiał i metody: Materiał poddany analizie stanowi grupa 20 dzieci leczonych w ośrodku poznańskim z powodu neuroblastoma (III i IV stopień zaawansowania). Metodologia badań, bazując na wytycznych protokołu leczenia neuroblastoma, sprowadza się do analizy wyników badań audiometrii tonalnej - jako badania subiektywnego (w rozszerzonym zakresie częstotliwości) oraz korelujących $\mathrm{z}$ audiometrią tonalną pod kątem specyficzności częstotliwościowej, pomiarów otoemisji akustycznych DPOAE - jako badania obiektywnego.

Wyniki: Analiza wyników badań w powyższej grupie wskazuje na charakterystyczny dla zjawiska ototoksyczności niedosłuch wysokoczęstotliwościowy o charakterze odbiorczym. Niedosłuch został potwierdzony zarówno w badaniach audiometrii tonalnej, jak i pomiarami otoemisji akustycznych. Często nie występował on jeszcze w zakresie standardowego zakresu częstotliwości, ale objawiał się obniżeniem progu słyszenia powyżej $8 \mathrm{kHz}$. Obniżenie progów słyszenia korelowało w tym zakresie $\mathrm{z}$ brakiem rejestracji DPOAE.

Wnioski: Monitorowanie zjawiska ototoksyczności przy użyciu audiometrii wysokoczęstotliwościowej i otoemisji akustycznych pozwala na precyzyjne kontrolowanie procesu terapeutycznego oraz jego efektów ubocznych. $Z$ uwagi na ograniczenia związane $\mathrm{z}$ audiometrią wysokoczęstotliwościową, pomocne może być posługiwanie się pomiarem DPOAE w zakresie wysokich częstotliwości.

Słowa kluczowe: ototoksyczność • neuroblastoma • otoemisjie DPOAE • audiometria tonalna wysokoczęstotliwościowa

\section{XVII.P.9 - Mikrochirurgia krtani - analiza materiału klinicznego}

\section{Microsurgery of the larynx - analysis of clinical material}

\section{K. Partycka-Pietrzyk, I. Szlązak, P. Toman, G. Mielnik-Niedzielska}

Klinika Otolaryngologii Dziecięcej, Foniatrii i Audiologii Uniwersytetu Medycznego w Lublinie

Cel pracy: Celem pracy jest przedstawienie wyników leczenia operacyjnego zmian krtani w materiale Kliniki.

Material i metody: Badaniem objęto 19 pacjentów operowanych w Klinice Laryngologii Dziecięcej w latach 2010-2014. 
Wyniki: Wiek pacjentów wahał się od 2 miesięcy do 20 lat. Przebadana grupa była zrównoważona pod względem płci. Najczęstszą przyczyną zgłaszania się dzieci celem leczenia operacyjnego krtani były brodawczaki krtani oraz polipy fałdów głosowych.

Wnioski: Metody stosowane przez nas są metodami powszechnie stosowanymi w takich przypadkach. Najczęstszymi przyczynami, z powodu których pacjenci zgłaszali się do Kliniki, były zaburzenia wentylacji oraz fonacji. Objawy te ustępowały po zastosowanym leczeniu. W niewielkim odsetku pacjenci wymagali reoperacji. Grupę tę stanowili pacjenci, którzy zgłosili się celem leczenia operacyjnego brodawczaków krtani.

Słowa kluczowe: krtań • brodawczaki krtani • mikrochirurgia $\bullet$ analiza

\section{XVII.P.10 • Wysokoczęstotliwościowy niedosłuch odbiorczy jako odległe następstwo indukowane $w$ procesie leczenia przeciwnowotworowego $\mathrm{w}$ grupie dzieci leczonych $\mathrm{z}$ powodu neuroblastoma}

\section{High frequency hearing loss as the long time side-effect induced in the process of anticancer therapy in children treated for Neuroblastoma}

\section{B. Polski, B. Pucher, J. Sroczyński, M. Kotowski, J. Szydłowski}

Klinika Otolaryngologii Dziecięcej Uniwersytetu Medycznego w Poznaniu

Cel pracy: Intensywny rozwój farmakoterapii chorób rozrostowych przynosi poza korzyściami stosowania najnowszych leków również zwiększone ryzyko pojawienia się w okresie późniejszym skutków ubocznych. W pracy przedstawiono problem zjawiska ototoksyczności związanej ze stosowaniem pochodnych platyny w przeciwnowotworowym procesie terapeutycznym neuroblastoma wśród dzieci.

Materiał i metody: Pracę oparto o badania słuchu przeprowadzone w grupie 20 dzieci leczonych w ośrodku Poznańskim $\mathrm{z}$ powodu rozpoznania III i IV stadium neuroblastoma. Protokół leczenia neuroblastoma, jako jeden $\mathrm{z}$ nielicznych, wprowadza zalecenia i wskazówki dotyczące monitorowania stanu słuchu. $Z$ uwagi na specyficzny charakter indukowanego w ten sposób niedosłuchu zaleca się monitorowanie stanu słuchu w oparciu o ściśle określone badania audiologiczne. Te stosunkowo proste metody diagnostyczne pozwalają zminimalizować lub wcześnie wykryć ewentualne ototoksyczne uszkodzenia słuchu, nawet jeśli nie wypływają one na socjalną wydolność pacjenta.

Wyniki: Z przeprowadzonych badań wyłania się obraz stosunkowo często pojawiającego się niedosłuchu odbiorczego o sensoneuronalnym, wysokoczęstotliwościowym charakterze, który w wielu przypadkach pozostaje utajony, niezauważony i nie wpływa na komunikatywne zdolności pacjenta.

Wnioski: W kontekście uzyskiwanych wyników badań i wytycznych zawartych w protokole leczenia Neuroblastoma można zauważyć, że nie wszystkie metody diagnostyczne są równie przydatne. Przez swój wysokoczęstotliwościowy charakter niedosłuch często pozostaje utajony, choć wkraczając w pole Fanta wpływa na wydolność komunikacyjną słuchu, tj. rozumienie mowy. Ponadto przyjęta do opisywania zjawiska ototoksyczności skala nie odzwierciedla w pełni zjawiska ototoksyczności.

Słowa kluczowe: ototoksyczność • neuroblastoma • niedosłuch wysokoczęstotliwościowy

\section{XVII.P.11 • Zachowanie się narządu słuchu w chorobach nerek u dzieci}

\section{The function of the organ of hearing in kidney diseases in children}

\section{Szlązak, G. Niedzielska}

Klinika Otolaryngologii Dziecięcej, Foniatrii i Audiologii Uniwersytetu Medycznego w Lublinie

Cel pracy: Celem pracy było uzyskanie odpowiedzi na pytanie, czy choroby nerek u dzieci lub zastosowane leczenie mogą mieć wpływ na stan narządu słuchu.

Materiał i metody: Badaniami przeprowadzonymi w ramach niniejszej pracy objęto 71 dzieci w wieku 1,5-17,5 lat, z chorobami nerek, hospitalizowanych w Klinice Pediatrii i Nefrologii Dziecięcej Uniwersytetu Medycznego w Lublinie w okresie od października 2008 do lutego 2014 r. W badanej grupie 71 osób chłopcy stanowili 73\% (52 przypadki), a dziewczynki 27\% (19 przypadków). Średni wiek pacjentów wynosił $9,5 \pm 4,5$ roku, a średni czas trwania choroby $2,4 \pm 2,5$ roku. Większość dzieci (52, co stanowi $73 \%$ ) leczona była $\mathrm{z}$ powodu zespołu nerczycowego, inne choroby to: ostra, przewlekła, schyłkowa niewydolność nerek, torbielowatość nerek, nadciśnienie tętnicze czy zapalenia nerek. Grupę kontrolną stanowiło 26 zdrowych dzieci, 13 chłopców i 13 dziewczynek, w wieku 4-17 lat (średni wiek 11,5 $\pm 4,2$ lat). Osoby zakwalifikowane do grupy kontrolnej cechowały się ujemnym wywiadem w kierunku chorób nefrologicznych, chorób uszu oraz niedosłuchu. $Z$ dokumentacji medycznej zanotowano parametry badań laboratoryjnych: CRP, posiewu moczu, poziomu białka w moczu, białka całkowitego we krwi, kreatyniny, mocznika, kwasu moczowego, cholesterolu oraz elektrolitów (sodu, potasu i wapnia) wykonanych w Klinice Nefrologii Dziecięcej podczas hospitalizacji, w trakcie której wykonano badania słuchu. Funkcje narządu słuchu w grupie badanej i kontrolnej oceniano za pomocą audiometrii impedancyjnej, audiometrii tonalnej, otoemisji akustycznej oraz wywołanych słuchowych potencjałów $\mathrm{z}$ pnia mózgu. Badanie słuchu poprzedzała otoskopia oraz pełna ocena laryngologiczna. 
Wyniki: Wykonane badania słuchu u dzieci z chorobami nerek wykazały gorsze wyniki w zakresie tympanometrii, obecności odruchów z m. strzemiączkowego, audiometrii progowej, latencji w badaniu $A B R$ w porównaniu z grupą kontrolną. Nie wykazano zależności występowania niedosłuchu od przyjmowanych leków ototoksycznych.

Wnioski: U dzieci z chorobami nerek częściej występują zaburzenia słyszenia niż w populacji dzieci zdrowych. Badania wykazały, że przyjmowanie leków ototoksycznych w chorobach nerek nie przyczynia się do zwiększenia częstości występowania trwałego niedosłuchu u tych dzieci. Przejściowe zaburzenie słyszenia obserwowano podczas stosowania Furosemidu.

Słowa kluczowe: choroby nerek • niedosłuch • leki ototoksyczne

\section{XVII.P.12 • Trudności w diagnostyce i rehabilitacji zawrotów głowy i zaburzeń układu równowagi u dzieci}

\section{Difficulties in diagnosis and rehabilitation vertigo and disorders the balance system in children}

\section{A. Pyda-Dulewicz ${ }^{1}$, R. Pepaś ${ }^{2}$, W. Konopka ${ }^{1,2}$}

${ }^{1}$ Uniwersytet Medyczny w Łodzi

${ }^{2}$ Instytut Centrum Zdrowia Matki Polki w Łodzi

Cel pracy: Celem badań była wstępna ocena przydatności technik integracji sensorycznej w rehabilitacji zawrotów głowy i zaburzeń układu równowagi u dzieci.

Materiał i metody: Badaniem wstępnym objęto 12 dzieci (7 dziewczynek i 5 chłopców) w wieku od 5 do 9 lat diagnozowanych z powodu zawrotów głowy i zaburzeń równowagi. U wszystkich badanych przeprowadzono diagnostykę otolaryngologiczną oraz otoneurologiczną, badania audiologiczne, a także wideonystagmografię. Następnie dzieci rehabilitowane były za pomoca technik integracji sensorycznej. Dla każdego badanego został stworzony indywidualny program terapii dostosowany do wieku i dysfunkcji. Ćwiczenia dobrano tak, aby dzieci mogły ćwiczyć także w domu - 4 razy dziennie po 15 minut.

Wyniki: Po 6 tygodniach terapii u 2 dzieci stwierdzono całkowite ustąpienie objawów, a 8 pacjentów deklarowało zmniejszenie dolegliwości.

Wnioski: Rehabilitacja westybularna za pomocą technik integracji sensorycznej przynosi oczekiwane efekty terapeutyczne, a dodatkowo jest ona dla dzieci ciekawą i atrakcyjną formą rehabilitacji w zawrotach głowy.

Słowa kluczowe: zawroty głowy • zaburzenia układu równowagi $\bullet$ rehabilitacja $\bullet$ układ przedsionkowy
XVII.P.13 • Ocena stanu układu równowagi u dzieci z niedosłuchem typu odbiorczego

\section{Evaluation of the balance system in children with sensorineural hearing loss}

\section{R. Pepaś ${ }^{1}$, M. Śmiechura ${ }^{1}$, A. Pyda-Dulewicz ${ }^{2}$, W. Konopka ${ }^{2}$}
${ }^{1}$ Klinika Otolaryngologii Instytutu Centrum Zdrowia Matki Polki w Łodzi
${ }^{2}$ Zakład Dydaktyki Pediatrycznej Uniwersytetu Medycznego $w €$ Łodzi

Cel pracy: Celem pracy była ocena stanu układu równowagi u dzieci z niedosłuchem typu odbiorczego.

Wyniki: W grupie dzieci z pogorszeniem słuchu zaobserwowano: skompensowane uszkodzenie obwodowej części układu równowagi rozpoznano u 5 badanych, a osłabienie funkcji błędnika współistniało z tożstronną głuchotą odbiorczą, u jednej osoby rozpoznano obustronną wrodzoną głuchotę z brakiem pobudliwości obu błędników, ośrodkowe uszkodzenie układu równowagi u 4 badanych, troje z głuchotą lewostronną, jedna osoba z obustronnym uszkodzeniem słuchu typu odbiorczego średniego stopnia. W grupie dzieci z prawidłowym słuchem skompensowane zmniejszenie pobudliwości błędnika niewielkiego stopnia rozpoznano u 2 badanych. Badanie wideonystagmograficzne bez odchyleń od stanu prawidłowego stwierdzono u 7 dzieci.

Wnioski: Głuchota może współistnieć z patologią części przedsionkowej ucha wewnętrznego nawet bez współistniejących zawrotów głowy.

Słowa kluczowe: zawroty głowy • niedosłuch

\section{XVII.P.14 • Zastosowanie testu VHIT $\mathrm{w}$ diagnostyce układu równowagi u dzieci}

\section{Application of the Video Head Impulse Test in the diagnosis of balance system in children}

\section{R. Pepaś ${ }^{1}$, A. Pyda-Dulewicz ${ }^{2}$, M. Śmiechura ${ }^{1}$, W. Konopka ${ }^{1,2}$}
${ }^{1}$ Klinika Otolaryngologii Instytutu Centrum Zdrowia Matki Polki w Łodzi
${ }^{2}$ Zakład Dydaktyki Pediatrycznej Uniwersytetu Medycznego $w$ Łodzi

Cel pracy: Ocena układu równowagi u dzieci z zastosowaniem testu VHIT.

Materiał i metody: Badaniem objęto 28 osób w wieku od 5 do 18 lat, w tym 9 dzieci z zawrotami głowy i 19 dzieci zdrowych. U badanych przeprowadzono szczegółowy wywiad, badanie laryngologiczne oraz otoneurologiczne, a także diagnostykę audiologiczną. U wszystkich badanych wykonano badanie VHIT z rejestracją odruchu 
przedsionkowo-ocznego i oceną współczynnika nadążania (gain). W grupie osób z zawrotami głowy dodatkowo przeprowadzono badanie wideonystagmograficzne.

Wyniki: W grupie dzieci zdrowych prawidłowe wyniki współczynnika nadążania gain stwierdzono u 14 pacjentów. W grupie dzieci z zawrotami głowy na podstawie pełnego badania VNG u dwóch pacjentów rozpoznano uszkodzenie obwodowej części układu równowagi. Wyniki testu VNG u tych pacjentów pokrywały się z wynikami badania VHIT dla poszczególnych kanałów półkolistych bocznych. U 7 dzieci stwierdzono uszkodzenie ośrodkowej części układu równowagi. U 4 pacjentów w tej grupie zaobserwowano nieprawidłowe wyniki testu VHIT.

Wnioski: Test VHIT pozwala w sposób szybki i nieinwazyjny przeprowadzić przesiewową analizę odruchu przedsionkowo-ocznego, wykrywając uszkodzenie na poziomie poszczególnych kanałów półkolistych. Test VHIT może stanowić uzupełnienie diagnostyki zawrotów głowy w warunkach klinicznych, a także być rozwiązaniem dla dzieci, które źle znoszą standardowe testy VNG.

Słowa kluczowe: zawroty głowy • układ równowagi • VHIT

\section{XVII.P.15 • Polimodalna terapia pacjentów jąkających się}

\section{Polimodal therapy of stuttering patients}

\author{
A. Rosińska ${ }^{1,2}$, H. Skarżyński ${ }^{1,2}$, \\ Z. M. Kurkowski ${ }^{1,2}$, K. Cieśla ${ }^{1,2}$ \\ ${ }^{1}$ Instytut Fizjologii i Patologii Słuchu, Warszawa/Kajetany \\ ${ }^{2}$ Światowe Centrum Słuchu IFPS $w$ Kajetanach
}

Cel pracy: W pracy chcemy pokazać zależność między kompleksową diagnostyką, która pozwala na ustalenie indywidualnej terapii osób jąkających się, a wynikami po terapii. Zaprezentujemy również trwałość wyników terapii, która jest widoczna poprzez wyniki badań na wizytach odległych. Odbywają się one minimum sześć miesięcy od zakończenia terapii.

Materiał i metody: Przebadana została 30-osobowa grupa pacjentów jąkających się. Te same testy wykonano przed terapią, po terapii i na wizycie odległej - kilka miesięcy po zakończeniu terapii. Była to grupa składająca się z 4 dziewczynek i 26 chłopców w wieku od 7 do 17 lat. Porównane zostały wyniki testów określających stopień płynności mowy, takich jak: Próba Sylabowa - Z. M. Kurkowskiego oraz Kwestionariusz do oceny stopnia niepłynności mówienia u dzieci (opr. M. Chęciek - mgr K. Węgierska). Wykonano również testy centralnych funkcji słuchowych, takie jak: Test rozdzielnousznego słyszenia, DDT obuusznie, DDT z ukierunkowaniem uwagi, długość fali P300 i porównano ich wyniki.

Wyniki: W wyniku przeprowadzonych analiz zaobserwowano, iż wartości wyników badań po terapii i na wizycie odległej są istotnie statystycznie większe po terapii oraz w badaniu odległym w porównaniu do badań wykonanych przed terapią.

Wnioski: W efekcie przeprowadzonych badań i porównania wyników testów przeprowadzonych po terapii widoczna jest tendencja do zmniejszenia stopnia niepłynności. Zachowanie istotnych statystycznie zmian na wizycie odległej, w stosunku do wyników sprzed terapii, może świadczyć o trwałości wyniku. Pacjentom jąkającym się daje to szansę na poprawę jakości życia. Jednocześnie wyniki badań potwierdzają konieczność oddziaływania na sferę emocji i lateralizację słuchową.

Słowa kluczowe: jąkanie • ośrodkowe funkcje słuchowe

\section{XVII.P.16 • Trening słuchowy SPS-S dla pacjentów $\mathrm{z}$ zaburzeniami koncentracji uwagi słuchowej współwystępującymi $z$ centralnymi zaburzeniami przetwarzania słuchowego}

\section{Auditory training SPS-S for patients with auditory attention deficits and central auditory processing disorders}

N. Czajka ${ }^{1,2}$, Z. M. Kurkowski $i^{1,2}$, D. Grudzieńn ${ }^{1,2}$, A. Skoczylas ${ }^{1,2}$, A. Rosińska ${ }^{1,2}$, H. Skarżyński ${ }^{1,2}$

${ }^{1}$ Instytut Fizjologii i Patologii Stuchu, Warszawa/Kajetany

${ }^{2}$ Światowe Centrum Stuchu IFPS $w$ Kajetanach

Cel pracy: Celem pracy jest przedstawienie treningu słuchowego SPS-S opracowanego dla pacjentów z zaburzeniami koncentracji uwagi słuchowej współwystępującymi z centralnymi zaburzeniami przetwarzania słuchowego.

Materiał i metody: Dla pacjentów wykazujących zaburzenia koncentracji uwagi słuchowej, u których rozpoznano także zaburzenia centralnych procesów przetwarzania słuchowego, opracowany został specjalny trening słuchowy. Pacjenci poddawani są stymulacji modyfikowanymi dźwiękami podawanymi przez specjalnie opracowane urządzenie za pośrednictwem przewodnictwa powietrznego i kostnego. Opracowana modyfikacja dźwięków, jak i sposób ich podawania, ćwiczy uwagę słuchową, stymuluje czynności ucha środkowego oraz procesy percepcyjno-motoryczne. Terapia składa się z kilku cykli, pierwszy z nich jest częścią bierną, podczas której pacjenci tylko słuchają przetworzonego materiału dźwiękowego. Kolejne etapy to części aktywne, które przeplatają bierne części treningu ćwiczeniami stymulującymi koordynację słuchowo-wzrokową, słuchowo-ruchową oraz słuchowo-wzrokowo-ruchową. Ćwiczenia aktywne oraz materiał dźwiękowy są dostosowywane do indywidualnych potrzeb pacjentów, ich trudności oraz wieku.

Wyniki: Wyniki pacjentów otrzymane z przeprowadzonych analiz wskazują na poprawę w zakresie rehabilitowanych podczas terapii wyższych funkcji słuchowych.

Wnioski: Zaprezentowane wyniki potwierdzają zasadność ukierunkowania oddziaływań rehabilitacyjnych w różnych grupach pacjentów. 
Słowa kluczowe: centralne zaburzenia przetwarzania słuchowego • zaburzenia koncentracji uwagi słuchowej • trening słuchowy

\section{XVII.P.17 • Trudności leczenia chirurgicznego wad rozwojowych pierwszego i drugiego łuku skrzelowego}

\section{Difficulties in surgical treatment I and II branchial arches anomalies}

\section{W. Brzoznowski, J. Kuczkowski, P. Krawczyński}

Klinika Otolaryngologii Uniwersytetu Medycznego w Gdańsku

Wstęp. Pozostałości embrionalnych łuków skrzelowych stanowią około $17 \%$ przyczyn wszystkich guzów szyi u dzieci. Anomalie skrzelopochodne mogą przybierać postać przetoki lub torbieli. Leczenie polega na chirurgicznym wycięciu.

Cel pracy: Omówienie trudności chirurgicznych w czasie leczenia wad rozwojowych I i II łuku skrzelowego.

Materiał i metoda: Na podstawie dokumentacji lekarskiej przeprowadzono badania retrospektywne dzieci $\mathrm{z}$ wadami rozwojowymi w obrębie głowy i szyi leczonych w Klinice Otolaryngologii w okresie od 1998 roku do 2014. Przeanalizowano dane epidemiologiczne, wyniki badań dodatkowych oraz protokoły operacyjne leczonych dzieci.

Wyniki: W omawianym okresie leczono 82 dzieci w wieku 1-18 lat, wśród których było 45 płci męskiej i 37 żeńskiej. U siedmiorga dzieci wykonano reoperacje.

Omówienie: Leczenie wad rozwojowych I i II łuku skrzelowego było chirurgiczne. Trudności w leczeniu sprawiały wady rozwojowe, których przebieg był nietypowy lub przypadki dzieci operowanych uprzednio w innym ośrodku.

Wnioski: Znajomość przewidywanego przebiegu anomalii skrzelopochodnych ułatwia bezpieczne i całkowite usunięcie każdej z nich.

\section{XVII.P.18 • Guzy nosa i zatok przynosowych u dzieci}

\section{Sinonasal tumors in children}

\section{T. Ryczer, M. Dębska, L. Zawadzka-Głos}

Klinika Otolaryngologii Dziecięcej Uniwersytety Medycznego $w$ Warszawie

Cel pracy: Celem pracy jest przedstawienie rzadkich przypadków guzów nosa i zatok przynosowych w populacji pediatrycznej. Z uwagi na różnorodny obraz kliniczny i w niektórych przypadkach niespecyficzność objawów należy podkreślić wagę uważnego badania laryngologicznego i diagnostyki w tej grupie pacjentów.
Materiał i metody: Przeprowadzono retrospektywną analizę kliniczną pacjentów hospitalizowanych w Klinice Otolaryngologii Dziecięcej WUM w latach 2012-2014. Oceniano lokalizację guza nosa i/lub zatok przynosowych, objawy, typ histologiczny oraz zastosowane leczenie.

Wyniki: W Klinice przebywało 17 dzieci (11 chłopców, 6 dziewczynek) z rozpoznanym guzem nosa bądź zatok przynosowych. Wiek pacjentów: od 1 miesiąca do 17 lat. Lokalizacje zmian obejmowały: jamę nosa, sitowie, zatokę szczękową, zatokę klinową oraz nosogardło. W 2 przypadkach guz penetrował do przedniego dołu czaszki, w jednym $z$ nich wchodząc do dołu podskroniowego. W innych 2 przypadkach guz penetrował do dołu skrzydłowo-podniebiennego. Większość pacjentów prezentowała upośledzoną drożność nosa, 4 pacjentów miało zaburzenia ruchomości gałki ocznej w wyniku nacieczenia oczodołu. Histologiczny charakter zmian: włókniak kostninowy (1), kostniak (1), glioma (1), xantogranuloma juvenile (1), naczyniak włosowaty (3), chłoniak Burkitta (1), chłoniak nieziarniczy (1), brodawczak odwrócony (1), rak płaskonabłonkowy (1), SGAT (1), hairy polyp (1), włókniak młodzieńczy (1), tętniakowata torbiel kostna (1), nodular fasciitis (1), przepuklina oponowo-nosowa (1). 14 pacjentów było poddanych leczeniu chirurgicznemu. U 3 pacjentów zastosowano chemioterapię.

Wnioski: Guzy nosa i zatok przynosowych u dzieci występują rzadko i wymagają dużej czujności diagnostycznej. Diagnostyka wczesna może być utrudniona u niemowląt i małych dzieci. Pacjenci z zaburzeniami ocznymi, takimi jak wytrzeszcz czy ograniczona ruchomość gałki ocznej wymagają pilnej konsultacji otorynolaryngologicznej. W badanej grupie dzieci dominowały guzy o charakterze łagodnym, lecz agresywne miejscowo.

Słowa kluczowe: guzy nosa $\bullet$ guzy zatok przynosowych • typ histologiczny $\bullet$ leczenie chirurgiczne $\bullet$ chemioterapia

\section{XVII.P.19 • Jak badać jakość życia związaną $\mathrm{z}$ stanem zdrowia u dzieci?}

\section{How to examine the quality of life related to the health of children?}

\section{Chmielik}

Klinika Otolaryngologii Dziecięcej Uniwersytetu Medycznego $w$ Warszawie

Cel pracy: Celem pracy jest przedstawienie elementów, które powinny mieć wpływ na dobór ankiet do badania jakości życia związanej z stanem zdrowia.

Materiał i metody: Na podstawie przeanalizowanej literatury i doświadczeń własnych przedstawiono kryteria, które powinno się uwzględniać wybierając ankietę do badania jakości życia. Istotnym jest, aby przy wyborze metody badawczej stosować narzędzia uniwersalne, umożliwiające odniesienie się do wyników uzyskanych w innych pracach dotyczących danego tematu. Podczas oceny jakości życia związanej z stanem zdrowia wyniki uzyskujemy na podstawie ankiet, które 
są wypełniane przez osobę badaną lub przez jego opiekuna (rodzica). Istotnym jest uświadomienie osobie wypełniającej ankietę że nie ma odpowiedzi „dobrych” lub „złych”.

Wyniki: Ankiety stosowane do badań jakości życia powinny mieć określoną swoistość i czułość w stosunku do problemu, który oceniają. Narzędzia winny być standaryzowane Każdej odpowiedzi przypisuje się według klucza odpowiednią wartość liczbową. Wyniki te są następnie opracowywane przy pomocy odpowiedniego algorytmu. Tak uzyskaną wartość umieszczamy na skali wyników do oceny jakości życia w danej ankiecie.

Wnioski: 1. Jasne określenie celu badania ułatwia dokonanie właściwego wyboru instrumentu badawczego. 2. Należy pamiętać, aby metoda badawcza była dostosowana do odpowiedniej grupy wiekowej. 3 . Wyniki badań powinny pozwalać na wykonanie porównania z wynikami badań innych naukowców. 4. Do badań powinny być stosowane standaryzowane ankiety.

\section{SESJA XVIII \\ 12:30-14:30 Chirurgia kości skroniowej - pokaz}

\section{J. Mierzwiński, A. Zwierz}

\section{SALA B}

\section{XIV.1 • Propranolol w leczeniu naczyniaków u dzieci w materiale Kliniki Otolaryngologii Dziecięcej WUM}

\section{Propranolol in the treatment of hemangioma in children}

\section{Jabłońska-Jesionowska, L. Zawadzka-Głos}

Klinika Otolaryngologii Dziecięcej Uniwersytetu Medycznego $w$ Warszawie

Cel pracy: Celem pracy jest przedstawienie skuteczności leczenia Propranololem doustnym naczyniaków u dzieci.

Material i metody: W Klinice ORL Dziecięcej WUM leczyliśmy 11 dzieci z powodu naczyniaka w wieku 2 miesięcy do 12 rż. W ramach diagnostyki wykonaliśmy endoskopię dróg oddechowych, TK z kontrastem. Przed włączeniem leczenia badania laboratoryjne, Ekg i Echo serca. Stosowano Propranolol w dawce $0,5-2 \mathrm{mg} / \mathrm{kg} \mathrm{mc}$ $3 \times$ na dobę. Podczas leczenia monitorowano RR i HR.

Wyniki: Po doustnej terapii Propranololem uzyskano całkowite wyleczenie naczyniaka u dzieci, u których leczenie rozpoczęto przed ukończeniem 1 roku życia. U dzieci starszych naczyniak uległ zmniejszeniu lub zwłóknieniu. Terapia trwała 3-6 miesięcy. Nie obserwowano powikłań podczas stosowania Propranololu.

Wnioski: Propranolol jest skuteczny w leczeniu naczyniaków u dzieci, jeżeli leczenie rozpocznie się przed ukończeniem 1 roku życia. Jest lekiem bezpiecznym. Podawanie preparatu, jak również monitorowanie leczenia, nie jest skomplikowane.

Słowa kluczowe: naczyniaki • dzieci • propranolol

\section{XIV.2 • Wrodzone anomalie naczyń tętniczych przyczyną wrodzonego stridoru oddechowego u dzieci}

\section{Congenital vascular anomalies an important cause of respiratory distress in children}

\section{Jabłońska-Jesionowska, L. Zawadzka-Głos}

Klinika Laryngologii Dziecięcej Uniwersytetu Medycznego $w$ Warszawie

Cel pracy: Celem pracy jest potwierdzenie konieczności wykonywania endoskopii krtani i tchawicy u dzieci z wrodzonym stridorem oddechowym.

Materiał i metody: Przeanalizowano 106 przypadków dzieci $\mathrm{z}$ wrodzonym stridorem oddechowym $\mathrm{w}$ wieku od 2 tygodni do 8,5 lat. W ramach diagnostyki wykonano w wszystkich dzieci: rtg klatki piersiowej, usg krtani, endoskopię kratni i tchawicy; u większości rtg przełyku $\mathrm{z}$ kontrastem, usg p/ciemiączkowe, ECHO serca, angio-CT klatki piersiowej.

Wyniki: Na podstawie badania endoskopowego krtani i tchawicy u 31 dzieci z wrodzonym stridorem oddechowym postawiono podejrzenie zwężenia dróg oddechowych spowodowane anomaliami wielkich naczyń tętniczych. Rozpoznanie potwierdzono badaniem angio-CT klatki piersiowej.

Wnioski: Każdy wrodzony stridor oddechowy u dzieci wymaga diagnostyki endoskopowej dróg oddechowych, nie tylko krtani, ale również tchawicy. Pierścienie naczyniowe są ważną przyczyną zwężenia dróg oddechowych powodującym ucisk z zewnątrz. Rozpoznawane są w każdym wieku dziecka. Badaniem rozstrzygającym przyczynę stridoru i kwalifikującym do leczenia chirurgicznego jest endoskopia dróg oddechowych.

Słowa kluczowe: anomalie naczyń tętniczych • pierścienie naczyniowe - stridor wrodzony - dzieci • laryngotracheoskopia 
XIV.3 • Zwężenia podgłośniowe - własne obserwacje

\section{Subglottic stenosis - own experience}

\section{Cofała, I. Bielecki, M. Dec}

Oddział Laryngologii, Górnośląskie Centrum Zdrowia Dziecka Śląskiego Uniwersytetu Medycznego w Katowicach

Cel pracy: Przedstawienie własnych 10-letnich doświadczeń w leczeniu zwężeń podgłośniowych.

Materiał i metody: Materiał obejmuje dzieci leczone z powodu wrodzonych i nabytych podgłośniowych zwężeń krtani.

Wyniki: Zaprezentowano własne obserwacje związane $\mathrm{z}$ operacjami wykonywanymi $\mathrm{z}$ dojścia zewnętrznego, tj. dekompresje, rekonstrukcje krtani i tchawicy z użyciem wszczepów, resekcje pierścienno-tchawicze. Przedstawiono wskazania i technikę zabiegów wykonywanych metodą endoskopową.

Wnioski: Rekonstrukcje krtani i tchawicy są skuteczną metodą leczenia wrodzonych i nabytych zwężeń krtani.

Słowa kluczowe: zwężenie podgłośniowe • dzieci

\section{XIV.4 • Wrodzone i nabyte zwężenia tchawicy}

\section{Congenital and acquired stenosis of the trachea}

M. Dec, A. Krzemień-Gabriel, M. Cofała, I. Bielecki

Oddział Laryngologii, Górnoślaskie Centrum Zdrowia Dziecka Śląskiego Uniwersytetu Medycznego w Katowicach

Cel pracy: Przedstawienie przypadków zwężeń tchawicy,

Materiał i metody: Materiał obejmuje dzieci leczone z powodu wrodzonych i nabytych zwężeń tchawicy.

Wyniki: Zwężenia tchawicy są najczęściej wywołane pierwotną lub wtórną wiotkością tchawicy. Zwężenia nabyte występują najczęściej w wyniku powikłań związanych z obecnością rurki tracheotomijnej. Objawy kliniczne pod postacia świstu wdechowo-wydechowego występują w przypadkach zwężenia co najmniej 50\% średnicy światła tchawicy.

Wnioski: Ponad 50\% zwężeń jest spowodowana wadami w zakresie układu sercowo-naczyniowego.

Słowa kluczowe: zwężenie tchawicy • dzieci
XIV.5 - Leczenie chirurgiczne obustronnego porażenia fałdów głosowych

- doświadczenia własne

\section{Surgical treatment of bilateral vocal cord paralysis - own experience}

\section{Dec, M. Cofała, I. Bielecki, T. Wolan}

Oddział Laryngologii, Górnośląskie Centrum Zdrowia Dziecka Śląskiego Uniwersytetu Medycznego w Katowicach

Cel pracy: Przedstawienie własnych obserwacji w leczeniu obustronnego porażenia fałdów głosowych.

Materiał i metody: Materiał obejmuje pacjentów leczonych z powodu obustronnego porażenia fałdów głosowych z dojścia zewnętrznego i endoskopowego.

Wyniki: Porażenie fałdów głosowych stanowi od 15\% do $20 \%$ wad rozwojowych krtani, w tym ponad $50 \%$ to porażenia obustronne. Główne przyczyny obustronnych porażeń obejmują wrodzone schorzenia w zakresie ośrodkowego układu nerwowego, zmiany pourazowe, a także zmiany o charakterze idiopatycznym. Ponad połowa przypadków wymaga wykonania tracheostomii. Samoistne powracanie funkcji fałdów głosowych obserwuje się od $46 \%$ do $64 \%$ przypadków w pierwszych 12 miesiącach życia, a u kolejnych $10 \%$ do 5 roku życia.

Wnioski: Nie ma jednolitego, powszechnie obowiązującego schematu postępowania.

Słowa kluczowe: porażenie fałdów głosowych

\section{XIV.6 • Naczyniak krwionośny tchawicy}

\section{Haemangioma of the trachea}

\section{J. Sroczyński ${ }^{1}$, B. Pucher ${ }^{1}$, M. Prauzińska ${ }^{1}$,}

J. Kolasińska-Lipińska' ${ }^{1}$, M. Kotowski ${ }^{1}$,

A. Bartkowska-Sniatkowska ${ }^{2}$, A. Pietrzak ${ }^{2}$, J. Szydłowski ${ }^{1}$

\footnotetext{
${ }^{1}$ Klinika Otolaryngologii Dziecięcej Uniwersytetu Medycznego w Poznaniu

${ }^{2}$ Klinika Anestezjologii i Intensywnej Terapii Pediatrycznej

Uniwersytetu Medycznego w Poznaniu
}

Cel pracy: Naczyniaki krwionośne są częstymi niezłośliwymi nowotworami okresu niemowlęcego. Występują u 4-10\% niemowląt. Naczyniaki dróg oddechowych ze względu na swoją lokalizację oraz szybki wzrost w okresie proliferacji stanowią szczególne niebezpieczeństwo.

Materiał i metody: Autorzy przedstawiają przypadek naczyniaka krwionośnego dolnego odcinka tchawicy u 2-miesięcznego dziecka. Pacjent przyjęty $\mathrm{z}$ powodu narastających trudności w oddychaniu, manifestujących się $\mathrm{w}$ trakcie karmienia oraz niepokoju. Badanie endoskopowe krtani i tchawicy wykazało duży guz obturujący światło tchawicy tuż ponad jej podziałem. Krytyczne zwężenie 
tchawicy zmusiło do zaintubowania dziecka pod kontrolą endoskopu. Leczenie zainicjowano na Oddziale Intensywnej Terapii. W leczeniu zastosowano Propranolol uzyskując szybką redukcję masy guza.

Wyniki: W pracy przedstawiono wyniki badań obrazowych oraz kryteria włączenia pacjenta do leczenia zachowawczego naczyniaka krwionośnego dróg oddechowych przy użyciu Propranololu.

Wnioski: Leczenie naczyniaków z zastosowaniem propranololu jest sprawdzoną metodą nieinwazyjną. Skuteczność leczenia jest największa, jeżeli leczenie rozpoczyna się w ciągu pierwszych 3 miesięcy życia.

Słowa kluczowe: naczyniaki krwionośne • propranolol • guzy łagodne dróg oddechowych

\section{XIV.7 • Postępowanie chirurgiczne w zwężeniach dystalnego odcinka tchawicy \\ Surgical management of distal tracheal stenosis}

\section{J. Kolasińska-Lipińska, B. Pucher, M. Kotowski, J. Sroczyński, J. Szydłowski}

Klinika Otolaryngologii Dziecięcej Uniwersytetu Medycznego w Poznaniu

Cel pracy: Celem pracy jest omówienie trudności diagnostycznych, zastosowanej techniki operacyjnej u pacjenta Kliniki oraz analiza piśmiennictwa dotyczącego postępowania w przypadku zwężenia dystalnego odcinka tchawicy.

Material i metody: Autorzy pracy przedstawiają przypadek niemowlęcia ze skorygowaną wcześniej wadą naczyniowa, operowanego wtórnie w Klinice Otolaryngologii Dziecięcej w Poznaniu z powodu krytycznego zwężenia dystalnego odcinka tchawicy.

Wyniki: Chirurgiczne leczenie zwężeń dystalnego odcinka tchawicy obejmuje cztery podstawowe techniki. Jest to plastyka tchawicy z użyciem osierdzia lub przeszczepu autologicznego, tracheoplastyka typu slide oraz poprzeczna resekcja tchawicy. Wszystkie te procedury wymagają dojścia operacyjnego poprzez sternotomię pośrodkową oraz wspomagania zabiegu krążeniem pozaustrojowym lub ECMO. Zabieg operacyjny zazwyczaj wykonywany jest jednoczasowo z korekcją wady naczyniowej. Zdarza się jednak, że w przypadku stwierdzenia wady naczyniowej, przedoperacyjna ocena endoskopowa dróg oddechowych nie jest rutynowo wykonywana. W okresie po zabiegu kardiochirurgicznym zwężenia niewielkiego stopnia pozostają często bezobjawowe.

Wnioski: W przypadku zwężeń znacznego stopnia, długoodcinkowych lub skojarzonych z wadą budowy chrząstek, objawy ograniczonej wydolności oddechowej narastają w czasie wraz z rozwojem dziecka. W okresie przed postawieniem właściwego rozpoznania pojawiają się zazwyczaj cechy wiotkości tchawicy, które „ustępują” po odkrztuszeniu wydzieliny. Prowadzona wówczas ewaluacja endoskopowa dróg oddechowych ujawnia rzeczywistą przyczynę zaburzeń oddechowych. Konieczne w tej sytuacji postępowanie chirurgiczne, $\mathrm{z}$ ponowną ingerencją w obrębie struktur klatki piersiowej, przysparza wielu dodatkowych trudności i podnosi ryzyko niepowodzenia zabiegu operacyjnego.

Słowa kluczowe: zwężenie tchawicy • wiotkość tchawicy - ring naczyniowy • podwójny łuk aorty

\section{XIV.8 • Długo zalegające ciało obce krtani - opis przypadku}

\section{Long term remaining laryngeal foreign body - case report}

\section{Kotowski, M. Prauzińska, J. Kolasińska- Lipińska, B. Pucher, J. Sroczyński, J. Szydłowski}

Klinika Otolaryngologii Dziecięcej Uniwersytetu Medycznego w Poznaniu

Cel pracy: Ciała obce dróg oddechowych stanowią poważny problem w laryngologii dziecięcej. Krtaniowa lokalizacja ciała obcego jest bezpośrednim zagrożeniem dla życia. Szczególnym wyzwaniem diagnostycznym i terapeutycznym są długo zalegające ciała obce.

Materiał i metody: Przedstawiamy przypadek 7-letniej dziewczynki z ciałem obcym w obrębie krtani zalegającym przez okres 6 lat.

Wyniki: Po incydencie związanym $\mathrm{z}$ aspiracją ciała obcego do dróg oddechowych w okresie niemowlęcym oraz następowym zabiegiem endoskopowym $\mathrm{z}$ towarzyszącymi powikłaniami, dziecko pozostawało po opieką ośrodka laryngologicznego, gdzie w kolejnych badaniach endoskopowych monitorowano stabilne, nieznaczne zwężenie okolicy podgłośniowej. W szóstym roku od epizodu aspiracji zaobserwowano gwałtowne narastanie zwężenia i skierowano dziecko do ośrodka zajmującego się leczeniem zwężeń krtaniowo-tchwiczych.

Wnioski: Prezentowany przypadek jest niezwykle pouczający z punktu widzenia szkoleniowego dla osób specjalizujących się w zakresie laryngologii oraz stanowi przyczynek do rozważań na temat etyki zachowań lekarskich.

Słowa kluczowe: ciało obce • krtań • dzieci 


\section{XIV.9 - Trudności diagnostyczne i terapeutyczne $w$ niedrożności krtani i tchawicy u dzieci}

\section{Diagnostic and therapeutic difficulties in the laryngeal and tracheal disturbances in children}

\author{
B. Pucher, J. Sroczyński, M. Kotowski, \\ J. Kolasińska-Lipińska, M. Ryglewicz, \\ M. Grzegorowski, J. Szydłowski
}

Klinika Otolaryngologii Dziecięcej Uniwersytetu Medycznego w Poznaniu

Cel pracy: Celem pracy jest analiza retrospektywna dokumentacji medycznej 9 pacjentów diagnozowanych i leczonych w Klinice z powodu niewydolności oddechowej.

Materiał i metody: W pracy przedstawiono najciekawsze opisy przypadków dzieci leczonych w Klinice Otolaryngologii Dziecięcej z powodu niedrożności krtani i tchawicy.

Wyniki: Wśród przyczyn niedrożności krtani i tchawicy w niniejszej pracy opisano: znacznych rozmiarów chłoniaka szyi i klatki piersiowej, zarośnięcie krtani, agenezję krtani, wrodzone i nabyte zwężenie krtani i tchawicy, pointubacyjne dwuodcinkowe zwężenie tchawicy, ciało obce tchawicy, guz tchawicy oraz trudności w intubacji u płodu z naczyniakiem głowy i szyi.

Wnioski: Na podstawie doświadczeń własnych oraz danych z literatury medycznej autorzy pracy podkreślają, że jedynie połączenie kilku metod diagnostycznych, zwłaszcza u noworodków, prowadzi do postawienia właściwego rozpoznania.

Słowa kluczowe: niedrożność dróg oddechowych • dzieci • diagnostyka

\section{XVI.1 • Europejski Konsensus Naukowy nt. Badań Przesiewowych Słuchu u Dzieci w Wieku Przedszkolnym i Szkolnym}

\author{
H. Skarżyński ${ }^{1,2}$, A. Piotrowska ${ }^{1,2}$ \\ ${ }^{1}$ Instytut Fizjologii i Patologii Słuchu, Warszawa/Kajetany \\ ${ }^{2}$ Światowe Centrum Stuchu IFPS $w$ Kajetanach
}

Europejski Konsensus Naukowy pn. „Badania przesiewowe słuchu u dzieci w wieku przedszkolnym i szkolnym" został przyjęty i podpisany przez przedstawicieli $27 \mathrm{kra}$ jów dnia 22 czerwca 2011 r. w Warszawie, w pierwszym dniu 10. Kongresu Europejskiej Federacji Towarzystw Audiologicznych. Propozycja wypracowania Konsensusu powstała $\mathrm{z}$ inicjatywy prof. Henryka Skarżyńskiego, który do współpracy zaprosił przedstawicieli środowiska audiologów i otolaryngologów, a także europejskich organizacji zrzeszających foniatrów, terapeutów mowy oraz okulistów.

W dokumencie podkreślono m.in. znaczenie i potrzebę prowadzenia programów badań przesiewowych słuchu u dzieci w wieku przedszkolnym i szkolnym, co ma na celu wczesne wykrywanie i diagnostykę uszkodzenia słuchu na skalę masową i z uwagi na wysoki odsetek dzieci z niedosłuchem jest istotnym zagadnieniem w ochronie zdrowia. Według piśmiennictwa światowego 1-2 na 1000 noworodków ma trwały ubytek słuchu. Odsetek dzieci z ubytkiem słuchu rośnie wraz z wiekiem, co wynika $\mathrm{z}$ nakładania się różnych czynników (genetycznych, środowiskowych, stylu życia). Wg raportu WHO (MBD, WHO, 2012 DHL estimates) odsetek dzieci ze znaczącym ubytkiem słuchu (ang: disabling hearing loss) w krajach Europy Środkowej wynosi $1,6 \%$. Według danych z Instytutu Fizjologii i Patologii Słuchu różne zaburzenia słuchu mogą dotyczyć nawet $20 \%$ populacji dzieci w wieku 6-18 lat.

W dokumencie zwrócono również uwagę na rolę władz lokalnych, takich jak np. samorządy terytorialne w podejmowaniu działań mających na celu organizowanie badań przesiewowych słuchu $\mathrm{w}$ ramach realizacji zadań $\mathrm{z}$ zakresu promocji i ochrony zdrowia, w tym także inicjowanie i udział w wytyczaniu kierunków przedsięwzięć lokalnych zmierzających do podnoszenia wiedzy i świadomości społeczeństwa nt. czynników szkodliwych dla zdrowia i predysponujących do występowania zaburzeń słuchu.

W pracy zostanie omówiony Europejski Konsensus Naukowy, jak również zostaną przedstawione wybrane programy badań przesiewowych słuchu u dzieci w wieku szkolnym realizowane w Polsce przez Instytut Fizjologii i Patologii Słuchu.

\section{XVI.2 • Krajowa sieć Teleaudiologii $\mathrm{w}$ badaniach przesiewowych słuchu u dzieci w wieku szkolnym}

\section{National Network of Teleaudiology in hearing screening of school-age children}

\author{
M. Ludwikowski ${ }^{1}$, P. H. Skarżyński ${ }^{1,2,3}$, A. Piłka ${ }^{1}$,
} P. Michaluk ${ }^{1}$, H. Skarżyński

\footnotetext{
${ }^{1}$ Instytut Fizjologii i Patologii Stuchu, Warszawa/Kajetany

${ }^{2}$ Zakład Niewydolności Serca i Rehabilitacji Kardiologicznej Uniwersytetu Medycznego w Warszawie

${ }^{3}$ Instytut Narządów Zmysłów, Kajetany
}

Cel pracy: Ocena zastosowania zaawansowanych narzędzi telemedycznych w badaniach przesiewowych słuchu u dzieci w wieku szkolnym.

Materiał i metody: Badania przesiewowe słuchu wykonano w grupie blisko 500000 uczniów szkół podstawowych w Polsce. Badania wykonywano za pomocą Platformy Badań Zmysłów wyposażonej w słuchawki audiometryczne Sennheiser HDA 200, stosując procedurę audiometrycznego wyznaczania progu słyszenia. Dodatni wynik badania słuchu oznaczał wartość progu słyszenia wynoszącą $25 \mathrm{~dB}$ i więcej (dla co najmniej jednej częstotliwości w przynajmniej jednym uchu).

Wyniki: Nieprawidłowy wynik badań przesiewowych, zgodnie z przyjętym kryterium, uzyskano u 8,6\% dzieci. 
Wnioski: Zastosowanie zaawansowanych narzędzi telemedycznych umożliwia sprawną realizację badań w dużej populacji oraz w krótkim czasie. Pozwala na monitorowanie jakości wykonywanych badań oraz szybką analizę otrzymanych wyników. Znaczący odsetek wyników dodatnich oraz bardzo duży odsetek rodziców, którzy nie mają świadomości występowania zaburzeń słuchu u swoich dzieci, wskazują na potrzebę wdrożenia powszechnych badań przesiewowych słuchu do medycyny szkolnej.

Słowa kluczowe: teleaudiologia • badania przesiewowe słuchu • dzieci w wieku szkolnym

\section{XVI.3 - Analiza przesiewowych badań słuchu w województwie lubelskim}

\section{Analysis of the results of hearing screening in Lublin province}

\section{K. Partycka-Pietrzyk, S. Kędzierawska, P. Puźniak, G. Mielnik-Niedzielska}

Klinika Otolaryngologii Dziecięcej, Foniatrii i Audiologii $w$ Lublinie

Cel pracy: Celem pracy jest ocena, w jakim odsetku nieprawidłowe wyniki badań odpowiedzi akustycznych z komórek słuchowych zewnętrznych wykonywanych przez przeszkolony personel na oddziałach noworodkowych maja swoje odzwierciedlenie w wynikach badań słuchu wykonywanych w ośrodku o III stopniu referencyjności. Przeanalizowano również najczęściej zgłaszane przez rodziców czynniki ryzyka uszkodzenia słuchu oraz ich ewentualną korelację ze stopniem niedosłuchu.

Materiał i metody: Analizie retrospektywnej poddano wyniki badań słuchu wszystkich dzieci skierowanych do dalszej diagnostyki w Poradni Audiologicznej Uniwersyteckiego Szpitala Dziecięcego w Lublinie do roku 2014.

Wyniki: W zdecydowanej większości przypadków podejrzenie niedosłuchu nie miało swojego potwierdzenia w badaniach wykonanych w ośrodku o III stopniu referencyjności. U pacjentów, u których badanie potencjałów wywołanych z pnia mózgu potwierdziło niedosłuch odbiorczy, rodzice najczęściej zgłaszali przebyte poważne infekcje, np. zapalenie opon mózgowo-rdzeniowych, wcześniactwo, zespół wad wrodzonych skojarzony z niedosłuchem oraz zastosowanie w terapii leków ototoksycznych.

Wnioski: Pierwsze miesiące życia dziecka określane często jako „złoty okres rozwoju mowy” są niezwykle ważne dla rozwoju przyszłych umiejętności komunikacji werbalnej, ponieważ mózg dziecka kształtuje się pod wpływem bodźców słuchowych docierających z otoczenia, m.in. mowy. Dzieci z uszkodzeniem słuchu, nie odbierające prawidłowo dźwięków pochodzących z otoczenia mają znacznie ograniczoną możliwość nauki mowy. Im późniejsze wykrycie uszkodzenia słuchu, a co za tym idzie wdrożenie postępowania leczniczego, tym mniejsza szansa, że dziecko nauczy się mówić. Powszechne przesiewowe badania słuchu u noworodków umożliwiają wczesne wykrycie niedosłuchu u dzieci do 6 miesiąca życia, co pozwala na odpowiednie zaaparatowanie dziecka oraz na podjęcie przez nie nauki słuchania i mówienia z możliwie największą skutecznością.

Słowa kluczowe: przesiewowe badania słuchu $\bullet$ noworodki • niedosłuch • potencjały wywołane z pnia mózgu • odpowiedź z komórek słuchowych zewnętrznych

\section{XVI.4 Program badań przesiewowych słuchu dla uczniów klas I i VI warszawskich szkół podstawowych}

\section{A. Zapert ${ }^{1,2}$, A. Piotrowska ${ }^{1,2}$, K. Tarczyński, ${ }^{1,2}$, A. Danielewicz ${ }^{1,2}$, M. Ludwikowski², K. Kochanek ${ }^{2}$, H. Skarżyński \\ ${ }^{1}$ Zakład Epidemiologii i Badań Przesiewowych Instytutu Fizjologii i Patologii Stuchu, Warszawa/Kajetany \\ ${ }^{2}$ Światowe Centrum Stuchu IFPS $w$ Kajetanach}

Wstęp: Od kilku lat Instytut Fizjologii i Patologii Słuchu na zlecenie Prezydenta m.st. Warszawy realizuje programy badań przesiewowych dla uczniów klas I i VI warszawskich szkół podstawowych. Zasadniczym celem programu jest wykrycie zaburzeń słuchu, które mogą utrudniać dziecku dostęp do informacji dźwiękowej oraz negatywnie wpływać na rozwój i funkcjonowanie dziecka w środowisku.

Cel: Przedstawienie wyników realizacji programów badań przesiewowych słuchu populacji uczniów klas I i VI szkół warszawskich w latach 2011-2014.

Materiał: Badaniami objęto łącznie 85005 uczniów klas I i VI warszawskich szkół podstawnych.

Metoda: U każdego dziecka wykonano audiometryczne badanie słuchu prawego i lewego ucha, dla tonów o częstotliwościach: $0,5,1,2,4,8 \mathrm{kHz}$. Pomiary wykonywano na urządzeniu do badań przesiewowych słuchu - Platformie Badań Zmysłów z zestawem słuchawkowym Sennheiser HDA 200. Wynik badania uznawano za prawidłowy, jeżeli próg słyszenia dla przewodnictwa powietrznego w zakresie częstotliwości od $0,5 \mathrm{kHz}$ do $8 \mathrm{kHz}$ nie przekraczał 20 dB HL.

Wyniki: W badanej grupie wiekowej odsetek wyników nieprawidłowych zawierał się w przedziale od 14 do $16 \%$ $\mathrm{w}$ kolejnych latach programu. W grupie dzieci z niedosłuchem ponad $60 \%$ stanowiły ubytki jednostronne.

Wnioski: Wyniki zrealizowanych Programów potwierdzają wysoki odsetek zaburzeń słuchu u dzieci w wieku szkolnym oraz zasadność prowadzenia badań przesiewowych słuchu w tej grupie wiekowej. 


\section{XVI.5 • Badania przesiewowe słuchu u dzieci w wieku szkolnym na trzech kontynentach}

\section{Hearing screening for school age children in three continents}

\author{
P. H. Skarżyński ${ }^{1,2,3}$ A. Piłka ${ }^{1}$, M. Ludwikowski ${ }^{1}$, \\ K. Kochanek ${ }^{1}$, H. Skarżyński ${ }^{1}$

\footnotetext{
${ }^{1}$ Instytut Fizjologii i Patologii Stuchu, Warszawa/Kajetany

${ }^{2}$ Zakład Niewydolności Serca i Rehabilitacji Kardiologicznej Uniwersytetu Medycznego w Warszawie

${ }^{3}$ Instytut Narzadów Zmysłów, Kajetany
}

Cel pracy: Zaburzenia słuchu często utrudniają bądź uniemożliwiają dziecku dostęp do informacji dźwiękowej, zakłócają również rozwój mowy, co w konsekwencji negatywnie wpływa na funkcjonowanie dziecka w społeczeństwie. Częstość występowania zaburzeń słuchu wśród dzieci wzrasta wraz z wiekiem i może obejmować różne rodzaje niedosłuchów, których nie udało się wykryć w trakcie badań przesiewowych u noworodków. Szacuje się, że 9-10 na 1000 dzieci może mieć trwały, jedno lub obustronny ubytek słuchu osiągając wiek szkolny. Programy badań przesiewowych słuchu umożliwiają wczesne wykrycie zaburzeń słuchu w danej grupie wiekowej, co pozwala na efektywne wdrożenie odpowiednich działań leczniczych, rehabilitacyjnych oraz profilaktycznych. Ocena stanu słuchu u dzieci w wieku szkolnym w wybranych szkołach w Europie, Azji Środkowej i Afryce.

Materiał i metody: Badania przesiewowe słuchu wykonano łącznie w grupie 1796 uczniów szkół podstawowych w Mołdawii, Rumunii, Rosji, Tadżykistanie, Kirgistanie, Azerbejdżanie, Armenii, Senegalu, na Wybrzeżu Kości Słoniowej. Badania wykonywano za pomocą Platformy Badań Zmysłów wyposażonej w słuchawki audiometryczne Sennheiser HDA 200, stosując procedurę audiometrycznego wyznaczania progu słyszenia. Dodatni wynik badania słuchu oznaczał wartość progu słyszenia wynoszącą 25 dB i więcej (dla co najmniej jednej częstotliwości w przynajmniej jednym uchu).

Wyniki: Europa: 3 kraje - dodatni wynik badań przesiewowych, zgodnie z przyjętym kryterium, uzyskano w grupie 62 uczniów z pośród 464 badanych, co stanowi 13,4\%. Azja Środkowa: 4 kraje - dodatni wynik badań przesiewowych, uzyskano w grupie 216 uczniów z pośród 1011 zbadanych, co stanowi 21,4\%. Afryka: 2 kraje - dodatni wynik badań przesiewowych, uzyskano w grupie 105 uczniów z pośród 321 zbadanych, co stanowi 32,7\%. Wynik wskazujący na występowanie jednostronnych zaburzeń słuchu uzyskało 64,5\%, 50\%, 53\% uczniów odpowiednio w Europie, Azji Środkowej, Afryce.

Wnioski: Uzyskane wyniki wskazują na wysoki odsetek występowania zaburzeń słuchu u dzieci w wieku szkolnym, co uzasadnia prowadzenie powszechnych badań przesiewowych słuchu u dzieci rozpoczynających naukę w szkole.

Słowa kluczowe: badania przesiewowe • zaburzenia słuchu - audiometryczne wyznaczanie progu słyszenia
XIX.1 • Ciała obce oczodołu u dzieci

Foreign bodies of the orbits in children

\section{J. Sroczyński, B. Pucher, J. Kolasińska-Lipińska, M. Kotowski, J. Szydłowski}

Klinika Otolaryngologii Dziecięcej Uniwersytetu Medycznego w Poznaniu

Cel pracy: Ciała obce oczodołów stanowią trudny problem kliniczny $\mathrm{z}$ uwagi na ogromne ryzyko trwałego pogorszenia wzroku. Do uszkodzenia narządu wzroku może dojść zarówno w chwili urazu, jak i w trakcie usuwania jego skutków. Rodzaj ciał obcych oraz zakres spowodowanych uszkodzeń cechuje ogromna różnorodność. Objawy będące efektem wniknięcia ciała obcego do oczodołu obejmują zaburzenia ostrości widzenia i ograniczenie ruchomości gałki ocznej. Ciała obce oczodołów, zwłaszcza mnogie i o organicznej budowie, sprawiają problemy diagnostyczne.

Materiał i metody: Przedstawiono opisy dwóch przypadków metalicznych ciał obcych (metaliczny fragment opakowania po aerozolu oraz śrut) w obrębie oczodołu u dzieci. Opisano proces diagnostyczny oraz metody usuwania ciał obcych oczodołu z zastosowaniem technik chirurgii otwartej oraz endoskopowych.

Wyniki: W jednym przypadku metaliczne ciało obce przedostało się przez dno oczodołu do światła zatoki szczękowej i spowodowało uszkodzenie mięśnia prostego dolnego. W drugim przypadku ciało obce zatrzymało się na granicy oczodołu prawego i ścian zatoki, nie wywołując zaburzeń ruchomości gałki ocznej lub zaburzeń widzenia.

Wnioski: Ciała obce oczodołu stanowią trudny problem $\mathrm{w}$ praktyce klinicznej. Przed podjęciem leczenia bardzo ważne jest zebranie dokładnego wywiadu wskazującego na okoliczności wniknięcia ciała obcego i jego przypuszczalny charakter (metaliczne lub niemetaliczne). Podkreśla się ważną rolę badań obrazowych (KT, USG), poprzedzających zabieg usunięcia ciała obcego. W każdym przypadku konieczna jest konsultacja okulistyczna zarówno przed, jak i pooperacyjna.

Słowa kluczowe: metaliczne ciało obce oczodołu

\section{XIX.2 • Wykorzystanie badań ultrasonograficznych dla ustalenia decyzji o zaopatrzeniu skutków urazów bocznej ściany nosa u dzieci}

\section{A. Michalak, M. Malicka, A. Zakrzewska}

Klinika Otolaryngologii, Audiologii i Foniatrii Dziecięcej, Uniwersytecki Szpital Kliniczny nr $4 \mathrm{w}$ Łodzi

Wstęp: Najczęściej urazy twarzoczaszki u dzieci występują pomiędzy 6-7 oraz powyżej $14 \mathrm{r} . \dot{z}$. Tym niemniej urazy nosa o charakterze stłuczenia lub krwiaków bez cech złamania występują także u dzieci młodszych, u których, 
ze względu na wiek badanie bywa najtrudniejsze. W przypadkach dużych zmian tkanek miękkich twarzy kliniczne rozpoznanie krwiaka bywa trudne. Natomiast narastanie krwiaków i możliwość ich zakażenia może być przyczyną poważnych następstw.

Cel: Celem badania jest wykorzystanie oceny dynamiki zmian pourazowych w tkankach miękkich twarzy do ustalenia decyzji o konieczności ewakuacji krwiaka.

Materiał i metody: Przedstawiono trzech pacjentów hospitalizowanych $\mathrm{z}$ powodu stłuczenia tkanek miękkich twarzy, u których, na podstawie dynamiki zmian w badaniu USG, ustalono rozpoznanie krwiaka bocznej ściany nosa, a także konieczność podjęcia decyzji o jego odbarczeniu.

Wyniki i wnioski: Badania USG, ze względu na swoją małą inwazyjność, mogą być powtarzane w krótkim czasie, dzięki czemu możliwe jest śledzenie dynamiki zmian pourazowych.

\section{XIX.3 • Dynamika rozwoju przewlekłego zapalenia zatok przynosowych u chorujących \\ na mukowiscydozę dzieci $\mathrm{z}$ różnymi mutacjami genotypu - doniesienie wstępne}

\section{Laryngological problems in children with different genetic mutations in the cystic fibrosis - preliminary reports}

\section{A. Sońta, A. Zakrzewska}

Klinika Otolaryngologii, Audiologii i Foniatrii Dziecięcej, Uniwersytecki Szpital Kliniczny nr 4 w Łodzi

Cel: Celem pracy jest ocena dynamiki objawów przewlekłego zapalenia zatok przynosowych $\mathrm{z}$ uwzględnieniem nieprawidłowości anatomicznych oraz patogenu kolonizującego błonę śluzową w odniesieniu do genotypu i wieku dzieci chorujących na mukowiscydozę.

Material i metody: Analizowano grupę 5 dzieci w wieku od 2 do 15 lat $\mathrm{z}$ rozpoznaną mukowiscydozą, które zostały skierowane do leczenia laryngologicznego z powodu nasilającej się trudności w oddychaniu przez nos. U wszystkich chorych wykonano badanie endoskopowe nosa $\mathrm{z}$ oceną ujść zatok przynosowych, pobrano wymaz z nosa oraz badanie obrazowe $w$ postaci tomografii komputerowej. $\mathrm{Z}$ uwagi na stwierdzone zmiany i brak poprawy po zastosowanym leczeniu zachowawczym, chorych kwalifikowano do leczenia operacyjnego metodą endoskopowej operacji zatok przynosowych.

Wyniki: Dwoje dzieci było homozygotami F508 del, troje różnego typu heterozygotami. U 4 chorych w wymazie $\mathrm{z}$ nosa wyhodowano Staphylococcus aureus, natomiast u 1 dziecka Enterobacter cloacae - ESBL(-). Zarówno w badaniu endoskopowym nosa, jak i tomografii komputerowej zmiany polipowate obustronnie stwierdzono u 4 pacjentów, u jednego jednostronne obejmujące zatoki szczękowe i komórki sitowe. Większe nasilenie zmian obserwowano po stronie skrzywionej przegrody nosa.

Wnioski: Najczęstszą mutacją u dzieci z mukowiscydozą jest F508 del. W przypadku homozygot przebieg choroby jest cięższy, objawy występują tuż po urodzeniu i dotyczą przewodu pokarmowego (niedrożność smółkowa) lub/i dolnych dróg oddechowych (nawracające, ciężkie zapalenia oskrzeli i płuc). Zmiany polipowate w obrębie zatok przynosowych i jamy nosa pojawiają się w późniejszym okresie życia (nawet u homozygot), a ich zaawansowanie wydaje się mieć związek z współwystępowaniem zaburzeń anatomicznych nosa. Najczęstszym patogenem kolonizującym błonę śluzową nosa u dzieci z mukowiscydozą jest Staphylococcus aureus. Dzieci z dodatnim testem przesiewowym w kierunku mukowiscydozy powinny być już od pierwszych lat życia objęte opieką wielospecjalistyczną, również laryngologiczną, nawet gdy nie prezentują jeszcze nasilonych zaburzeń drożności nosa.

Słowa kluczowe: mukowiscydoza $\bullet$ genotyp $\bullet$ dzieci $\bullet$ przewlekłe zapalenie zatok przynosowych z polipami

\section{XIX.4 - Mukocele zatok przynosowych u dzieci - opisy przypadków}

\section{A. Sońta, Z. Kozłowski, A. Zakrzewska}

Klinika Otolaryngologii, Audiologii i Foniatrii Dziecięcej, Uniwersytecki Szpital Kliniczny nr 4 w Łodzi

W przebiegu nieleczonego, bądź nieprawidłowo leczonego przewlekłego zapalenia zatok przynosowych, mogą rozwinąć się powikłania. Jednym z nich jest torbiel śluzowa (mucocele) zatok przynosowych. U dzieci jest rzadko spotykana. Powolny i wieloletni przebieg rozwoju śluzowiaka w zatokach powoduje późne pojawienie się objawów klinicznych powodowanych uciskiem i uszkodzeniem rozdętych ścian zatok. Wtórne zakażenie może prowadzić do powstania mukopyocele. Dolegliwości związane z chorobą są często niespecyficzne, co powoduje prowadzenie długotrwałej diagnostyki przez neurologów, okulistów czy też podejrzenie choroby rozrostowej.

Przedstawiono przypadki dwóch nastoletnich pacjentów leczonych przed podjęciem diagnostyki laryngologicznej przez kilka lat przez różnych specjalistów. U pierwszej pacjentki powodem długotrwałych bólów głowy okazało się mukocele zatoki czołowej, u drugiego pacjenta mukocele w obrębie sitowia powodujące odkształcenie w obrębie oczodołu, co wzbudziło podejrzenie guza oczodołu w badaniu okulistycznym. Autorzy zwracają uwagę na współistnienie przewlekłych chorób błony śluzowej nosa - w przedstawionych przypadkach przewlekły alergiczny nieżyt nosa oraz nieprawidłowości anatomiczne dodatkowo wpływają na zaburzenia drożności nosa. 


\section{XIX.5 • Obustronne niewykształcenie nozdrzy tylnych $w$ materiale Kliniki Otolaryngologii Dziecięcej w Poznaniu}

\section{Bilateral choanal atresia treatment in Pediatric ENT Department in Poznan}

\section{J. Kolasińska-Lipińska, I. Chwirot-Głyda, M. Kotowski, B. Pucher, M. Ryglewicz, J. Sroczyński, J. Szydłowski}

Klinika Otolaryngologii Dziecięcej Uniwersytetu Medycznego w Poznaniu

Cel pracy: Celem pracy jest ocena skuteczności zastosowanego w Klinice schematu postępowania w leczeniu niewykształconych nozdrzy tylnych.

Materiał i metody: W ciągu ostatnich 42 lat w Klinice Otolaryngologii Dziecięcej w Poznaniu z powodu niewykształconych nozdrzy tylnych leczonych było 112 dzieci obojga płci. W 47 (42\%) przypadkach wada miała charakter obustronny, a w 65 (58\%) jednostronny. W 75\% wszystkich przypadków anomalii nozdrzy tylnych towarzyszyły inne wady wrodzone. 7 dzieci w okresie poprzedzającym zabieg miało wykonaną tracheotomię ( $4 \mathrm{w}$ innym ośrodku). W 101 (90\%) przypadkach zastosowano dostęp przez jamę nosową wspomagany instrumentarium endoskopowym. W 11 (10\%) przypadkach zastosowano dostęp przezpodniebienny.

Wyniki: W każdym przypadku w okresie pooperacyjnym drożność zrekonstruowanych nozdrzy zabezpieczano za pomocą separatorów. Od 2010 roku podczas każdej operacji rekonstrukcyjnej stosowano miejscowo Mitomycynę C. W okresie 4-6 tygodni od zabiegu wykonywano kontrolne badanie endoskopowe. Od momentu wdrożenia do leczenia schematu postępowania $\mathrm{z}$ Mitomycyną $\mathrm{C} \mathrm{z}$ jednoczasowym stentowaniem nie stwierdzono restenozy. W 2 przypadkach podczas zabiegu typu second look konieczne było usunięcie narastającej ziarniny.

Wnioski: Schemat postępowania obejmujący dojście operacyjne przez jamę nosową wraz z miejscowym zastosowaniem Mitomycyny C oraz jednoczasowym stentowaniem wydaje się być skutecznym w leczeniu rekonstrukcyjnym niewykształconych nozdrzy tylnych.

Słowa kluczowe: niewykształcenie nozdrzy tylnych $\bullet \mathrm{Mi}$ tomycyna $\mathrm{C} \cdot \mathrm{CHARGE}$

\section{XIX.6 - Ostre zapalenie ucha środkowego u dzieci - analiza pacjentów hospitalizowanych $w$ Klinice Otolaryngologii Dziecięcej WUM}

\section{E. Niemczyk, M. Dębska, L. Zawadzka-Głos}

Klinika Otolaryngologii Dziecięcej Uniwersytetu Medycznego $w$ Warszawie

Wstęp: Ostre zapalenie ucha środkowego (OZUŚ) należy do najczęstszych chorób infekcyjnych w populacji dziecięcej. Może prowadzić do groźnych dla życia powikłań.

Cel: Ocena etiopatologii OZUŚ u dzieci, częstości występowania powikłań, wskazań do zabiegu operacyjnego, stosowanej antybiotykoterapii oraz efektywności leczenia.

Materiał i metody: Retrospektywna analiza pacjentów hospitalizowanych z powodu OZUŚ w roku 2014 w Klinice Laryngologii Dziecięcej Warszawskiego Uniwersytetu Medycznego.

Wyniki: W roku 2014 hospitalizowano 71 pacjentów z OZUŚ, z czego 61\% stanowili chłopcy, a 39\% dziewczynki. $62,5 \%$ pacjentów prezentowało obustronne objawy. Objawy zgłaszane przez rodziców to: gorączka, ból ucha, wyciek $\mathrm{z}$ ucha, nawracające lub przedłużające się zapalenia ucha, biegunka, wymioty. $61,5 \%$ pacjentów było leczonych wcześniej nieefektywnie przez lekarza pierwszego kontaktu. U $10 \%$ pacjentów przy przyjęciu stwierdzono powikłania w postaci ostrego zapalenia wyrostka sutkowatego. 64\% pacjentów wymagało leczenia operacyjnego. U $12 \%$ pacjentów wykonano antromastoidektomię z tympanopunkcją lub drenażem wentylacyjnym, u 52\% wykonano samą tympanopunkcję. W 36\% wymazów zidentyfikowano patogen powodujący infekcję. Wśród nich dominował S. pneumoniae $(62,5 \%)$. U 74\% pacjentów uzyskano poprawę stosując empiryczna antybiotykoterapię. U 26\% zastosowano antybiotykoterapię celowaną: meropenem, trimetoprim-sulfametoksazol lub ceftazydym. Hospitalizacja trwała średnio 7,8 doby $z$ kontynuacja doustnego leczenia przeciwbakteryjnego przez średnio 6,7 dnia. U 5,5\% dzieci wystąpił nawrót objawów.

Wnioski: OZUŚ u dzieci może być efektywnie leczone przez lekarza pierwszego kontaktu. Nie leczące się OZUŚ, stan grożący perforacją błony bębenkowej, obecność powikłań OZUŚ są wskazaniem do hospitalizacji w Oddziale Laryngologii Dziecięcej.

\section{XIX.7 • Pierwotna dyskineza rzęsek: jak rozpoznać, jak leczyć?}

\section{Primary Ciliary Dyskinesia: How to bring the diagnosis, how to treat?}

\section{K. Raczkowska-Łabuda, L. Zawadzka-Głos}

Klinika Otolaryngologii Dziecięcej Uniwersytetu Medycznego $w$ Warszawie

Cel pracy: Charakterystyka zespołu PCD, akcentacja trudności diagnostycznych i rozbieżności terapeutycznych. 
Materiał i metody: Praca poglądowa, przegląd literatury i wytycznych różnych Towarzystw.

Wyniki: Objawy obejmują ARDS w wieku wczesno-niemowlęcym, nawracające infekcje dolnych dróg oddechowych, przewlekłe rhinosinusitis i zapalenie ucha środkowego, czy zaburzenia płodności. PCD wymaga różnicowania $\mathrm{z}$ atypową astmą, rozstrzeniem oskrzeli, mukowiscydozą. Diagnostyka zespołu to kaskada testów rozstrzygających (pobranie rzęsek szczoteczką cytologiczną, ocena ruchomości rzęsek w mikroskopie kontrastowo-fazowym, wideomikroskopowa obserwacja/rejestracja ruchliwości rzęsek, częstość uderzeń, charakterystyka „falowania” cili, ocena w mikroskopie elektronowym, badania immunochemiczne, badanie genetyczne) poprzedzonych testami przesiewowymi (test sacharynowy, pomiar nNO).

Wnioski: 1. Pierwotna Dyskineza Rzęsek rzadko jest uwzględniana w diagnostyce różnicowej przewlekłych infekcji GDO. 2. Łatwo dostępne testy przesiewowe nie mają zastosowania u docelowej grupy pacjentów (wysoki koszt testów rozstrzygających podstawowym ograniczeniem diagnostycznym. 3. Konieczność różnicowania pierwotnej i wtórnej dyskinezy rzęsek. 4. Brak jednolitego algorytmu prowadzenia pacjentów z rozpoznanym PCD - obligatoryjność wprowadzenia standardów terapii.

Słowa kluczowe: pierwotna dyskineza rzęsek • zespół nieruchomych rzęsek • klirens rzęskowy • zespół Kartagenera

\section{1 - Zastosowanie implantu ucha środkowego Vibrant Soundbridge w złożonych wadach wrodzonych narządu słuchu u dzieci}

\section{Application of a middle ear implant - Vibrant Soundbridge in congenital malformations of hearing organ in children}

\author{
H. Skarżyński ${ }^{1}$, M. Porowski ${ }^{1}$, L. Olszewski ${ }^{1}$, \\ P. H. Skarżyński ${ }^{1,2,3}$

\footnotetext{
${ }^{1}$ Instytut Fizjologii i Patologii Stuchu, Warszawa/Kajetany

${ }^{2}$ Zakład Niewydolności Serca i Rehabilitacji Kardiologicznej Uniwersytetu Medycznego $w$ Warszawie

${ }^{3}$ Instytut Narządów Zmysłów, Kajetany
}

Cel pracy: Implanty ucha środkowego stanowią alternatywną metodę poprawy słuchu w zaawansowanych chorobach ucha środkowego. Urządzenia te znajdują zastosowanie również $\mathrm{w}$ złożonych wadach wrodzonych ucha środkowego i zewnętrznego, w tym także u dzieci. Celem niniejszej pracy było przedstawienie metody chirurgicznej oraz ocena wyników zastosowania urządzenia Vibrant Soundbridge w wybranych wadach wrodzonych narządu słuchu u pacjentów poniżej 18 roku życia.

Materiał i metody: Przedstawiona grupa pacjentów to osoby poniżej 18 roku życia $\mathrm{z}$ różnymi wadami wrodzonymi ucha środkowego i zewnętrznego, u których zastosowano leczenie niedosłuchu wykorzystując Vibrant Soundbridge. Sposoby dostępu do ucha środkowego w tych przypadkach obejmowały zachyłek nerwu twarzowego oraz attykotomię tylną. Przedstawiono różne sposoby umocowania przetwornika na kosteczkach słuchowych. Przedyskutowano wskazania i ograniczenia zastosowania Vibrant Soundbridge $\mathrm{w}$ tej grupie wiekowej.

Wyniki: W zdecydowanej większości przypadków korzyści zastosowania tego typu urządzeń są znaczne.

Wnioski: Doceniają to pacjenci, u których niemożliwe było zastosowanie klasycznych wewnątrzprzewodowych aparatów słuchowych z powodu obecności wad wrodzonych, zwłaszcza atrezji przewodu słuchowego zewnętrznego.

Słowa kluczowe: implant ucha środkowego • wady wrodzone narządu słuchu $\bullet$ dzieci

\section{2 • Zastosowanie audiometrii wysokoczęstotliwościowej i otoemisji akustycznych DPOAE do oceny ototoksyczności leczenia przeciwnowotworowego}

\section{The use of high frequency pure tone audiometry (HF-PTA) and distortion product otoacoustic emissions (DPOAEs) for evaluation the ototoxicity of anticancer therapy}

B. Polski, J. Sroczyński, B. Pucher, M. Kotowski, J. Szydłowski

Klinika Otolaryngologii Dziecięcej Uniwersytetu Medycznego w Poznaniu

Cel pracy: Proces leczenia przeciwnowotworowego u dzieci wiąże się niejednokrotnie z koniecznością zastosowania pochodnych platyny, które w swoim ubocznym działaniu mogą prowadzić do nabytych odbiorczych niedosłuchów o charakterze wysokoczęstotliwościowym. Monitorowanie tego zjawiska przy użyciu audiometrii wysokoczęstotliwościowej i fotoemisji akustycznych produktu zniekształceń nieliniowych ślimaka, pozwala na wykrycie pierwszych symptomów niedosłuchu, nawet gdy nie jest on odczuwalny dla pacjenta i nie wpływa na zdolności rozumienia mowy.

Materiał i metody: Materiał poddany analizie stanowi grupa 20 dzieci leczonych w Ośrodku Poznańskim z powodu Neuroblastoma (III i IV stopień zaawansowania). Metodologia badań, bazując na wytycznych protokołu leczenia Neuroblastoma, sprowadza się do analizy wyników badań audiometrii tonalnej - jako badania subiektywnego (w rozszerzonym zakresie częstotliwości) oraz korelujących $\mathrm{z}$ audiometrią tonalną pod kątem specyficzności częstotliwościowej, pomiarów otoemisji akustycznych DPOAE - jako badania obiektywnego.

Wyniki: Analiza wyników badań w powyższej grupie wskazuje na charakterystyczny dla zjawiska ototoksyczności niedosłuch wysokoczęstotliwościowy o charakterze odbiorczym. Niedosłuch został potwierdzony zarówno 
w badaniach audiometrii tonalnej, jak i pomiarami otoemisji akustycznych. Często nie występował on jeszcze w zakresie standardowego zakresu częstotliwości, ale objawiał się obniżeniem progu słyszenia powyżej $8 \mathrm{kHz}$. Obniżenie progów słyszenia korelowało $\mathrm{w}$ tym zakresie $\mathrm{z}$ brakiem rejestracji DPOAE.

Wnioski: Monitorowanie zjawiska ototoksyczności przy użyciu audiometrii wysokoczęstotliwościowej i otoemisji akustycznych pozwala na precyzyjne kontrolowanie procesu terapeutycznego oraz jego efektów ubocznych. Z uwagi na ograniczenia związane $\mathrm{z}$ audiometrią wysokoczęstotliwościową pomocne może być posługiwanie się pomiarem DPOAE w zakresie wysokich częstotliwości.

Słowa kluczowe: ototoksyczność • neuroblastoma • otoemisje DPOAE • audiometria tonalna wysokoczęstotliwościowa

\section{3 • Zastosowanie implantu $z$ elektrodą SRA $w$ populacji dziecięcej $z$ resztkami słuchu}

\section{Application of implants with SRA electrode in children population with residual hearing}

\author{
H. Skarżyński ${ }^{1}$, M. Matusiak ${ }^{1}$, M. Porowski ${ }^{1}$, \\ P. H. Skarżyński ${ }^{1,2,3}$, A. Lorens ${ }^{1}$ \\ ${ }^{1}$ Instytut Fizjologii i Patologii Stuchu, Warszawa/Kajetany \\ ${ }^{2}$ Zakład Niewydolności Serca i Rehabilitacji Kardiologicznej \\ Uniwersytetu Medycznego $w$ Warszawie \\ ${ }^{3}$ Instytut Narządów Zmysłów, Kajetany
}

Cel pracy: Implanty ślimakowe są powszechnie uznaną metodą rehabilitacji osób dorosłych i dzieci z głębokim ubytkiem słuchu. Wprowadzenie metody leczenia częściowej głuchoty pozwoliło na rozszerzenie wskazań do stosowania implantów i pomoc większej liczbie pacjentów, w tym również dzieci. Rozwój techniki operacyjnej i współpraca pomiędzy naukowcami z wiodących ośrodków klinicznych otochirurgicznych dały możliwość na stworzenie coraz lepszych rozwiązań cechujących się odpowiednio elastyczną elektrodą, pozwalającą na zachowanie resztek słuchu. Celem niniejszej pracy było przedstawienie metody chirurgicznej oraz ocena wyników zastosowania implantu z elektrodą SRA w grupie dzieci z wadą słuchu $\mathrm{w}$ postaci głębokiego ubytku zmysłowo-nerwowego $\mathrm{z}$ zachowanymi funkcjonalnymi resztkami.

Material i metody: Przedstawiona grupa pacjentów to osoby poniżej 18 roku życia $\mathrm{z}$ wadą słuchu w postaci głębokiego ubytku zmysłowo-nerwowego $\mathrm{z}$ zachowanymi funkcjonalnymi resztkami, u których zastosowano leczenie niedosłuchu wykorzystując implant Nucleus z elektrodą SRA. Metoda chirurgiczna obejmowała 6-stopniową procedurę leczenia częściowej głuchoty, wykorzystując okienko okrągłe jako miejsce wprowadzenia elektrody.

Wyniki: W zdecydowanej większości przypadków korzyści zastosowania tego typu urządzeń są znaczne.
Wnioski: Zachowanie resztek słuchu uzyskano u ponad 90\% pacjentów.

Słowa kluczowe: zachowanie resztek słuchu • elektroda SRA • populacja dziecięca

\section{4 • Ocena skuteczności treningu słuchowego SPS-S prowadzonego u pacjentów $z$ zaburzeniami koncentracji uwagi słuchowej współwystępującymi $z$ centralnymi zaburzeniami przetwarzania słuchowego}

\section{Assessment of the effectiveness of auditory training SPS-S conducted in patients with auditory attention deficits and central auditory processing disorder}

N. Czajka1,2, Z. M. Kurkowskii,2, D. Grudzieńn ${ }^{1,2}$, A. Skoczylas ${ }^{1,2}$, A. Rosińska ${ }^{1,2}$, H. Skarżyński ${ }^{1,2}$

${ }^{1}$ Instytut Fizjologii i Patologii Słuchu, Warszawa/Kajetany

${ }^{2}$ Światowe Centrum Słuchu IFPS $w$ Kajetanach

Cel pracy: Celem pracy jest ocena skuteczności treningu słuchowego prowadzonego u pacjentów z zaburzeniami koncentracji uwagi słuchowej współwystępującymi z centralnymi zaburzeniami przetwarzania słuchowego.

Materiał i metody: Materiał do pracy stanowią wyniki 110 pacjentów z zaburzeniami koncentracji uwagi słuchowej współwystępującymi z centralnymi zaburzeniami przetwarzania słuchowego, którzy wzięli udział w specjalnie opracowanym dla tej grupy pacjentów treningu słuchowym. Przeprowadzona terapia, w swoich założeniach, w największym stopniu oddziałuje na zmysł słuchu, kolejno zaś na koordynację słuchowo-wzrokową, słuchowo-ruchową oraz słuchowo-wzrokowo-ruchową. Pacjenci poddawani są stymulacji modyfikowanymi dźwiękami podawanymi przez specjalnie opracowane urządzenie za pośrednictwem przewodnictwa powietrznego i kostnego. Opracowana modyfikacja dźwięków, jak i sposób ich podawania ćwiczy uwagę słuchową, stymuluje czynności ucha środkowego oraz procesy percepcyjno-motoryczne.

Wyniki: Ocena efektów terapii dokonana została na podstawie wyników w zakresie testów badających wyższe funkcje słuchowe: FPT, DPT, GDT, DDT (obuusznie oraz z ukierunkowaniem uwagi), aSPN, TRS (obuusznie oraz $\mathrm{z}$ ukierunkowaniem uwagi). Testy zostały przeprowadzone dwukrotnie: podczas diagnostyki pacjenta przed rozpoczęciem terapii oraz po jej zakończeniu.

Wnioski: Wyniki otrzymane ze wstępnie przeprowadzonych analiz statystycznych wskazują na poprawę w zakresie rehabilitowanych podczas terapii wyższych funkcji słuchowych. Potwierdza to zasadność ukierunkowania oddziaływań rehabilitacyjnych w różnych grupach pacjentów.

Słowa kluczowe: centralne zaburzenia przetwarzania słuchowego • zaburzenia koncentracji uwagi słuchowej • trening słuchowy 
XX. 5 • Zastosowanie kliniczne pomiarów tympanometrii szerokopasmowej u dzieci - doniesienie wstępne

\section{Clinical applications of wideband tympanometry in children - preliminary report}

M. Kotowski, B. Pucher, B. Polski, J. Kolasińska-Lipińska, J. Sroczyński, J. Szydłowski

Klinika Otolaryngologii Dziecięcej Uniwersytetu Medycznego w Poznaniu

Cel pracy: Tympanometria szerokopasmowa (WBT) jest narzędziem diagnostycznym z zakresu audiometrii impedancyjnej, umożliwiającym pomiary absorbancji ucha środkowego w funkcji szerokiego zakresu częstotliwości $226 \mathrm{~Hz}-8 \mathrm{kHz}$, dającym możliwość oceny tympanogramów dla poszczególnych częstotliwości bodźca, uśrednionych oraz tympanogramów częstotliwości rezonacyjnej. Dotychczasowe badania wskazują, iż metoda ta może mieć szczególne zastosowanie w skriningu noworodkowym oraz diagnostyce takich patologii jak: obecność płynu w jamie bębenkowej, otoskleroza, przerwanie ciągłości łańcucha kosteczek, nadmiernie wiotka błona bębenkowa, dehicencje na kanale półkolistym. Celem pracy była próba oceny przydatności klinicznej WBT w diagnostyce i monitorowaniu pooperacyjnym u pacjentów $\mathrm{z}$ wysiękowym zapaleniem ucha środkowego (COME).

Materiał i metody: Grupę badaną stanowiło 12 dzieci $\mathrm{z}$ niedosłuchem o charakterze przewodzeniowym i śródoperacyjnie potwierdzonym COME. Ocenę audiologiczną obejmującą DP-OAE, IA $(226 \mathrm{~Hz})$, PTA (w wybranych przypadkach) oraz WBT przeprowadzono dwukrotnie: przedoperacyjnie oraz $\mathrm{w}$ okresie pooperacyjnym, cztery tygodnie po zabiegu.

Wyniki: Dokonano analizy otrzymanych wyników pod kątem przydatności klinicznej stosowania pomiarów WBT u dzieci.

Wnioski: Metoda tympanometrii szerokopasmowej wydaje się być obiecującą alternatywą dla klasycznych pomiarów audiometrii impedancyjnej u dzieci. Ze względu na możliwość dokonywania pomiarów absorbancji bez zmian ciśnienia znajduje zastosowanie w monitorowaniu efektów leczenia bezpośrednio w okresie pooperacyjnym.

Słowa kluczowe: tympanometria szerokopasmowa $\bullet$ absorbancja $\bullet$ przewlekłe wysiękowe zapalenie ucha środkowego
XX. 6 • Wartość diagnostyczna tympanometrii szerokopasmowej w chorobach ucha środkowego u dzieci - doświadczenia własne

\section{Diagnostic value multifrequency tympanometry middle ear diseases of children - our experience}

\section{B. Jagosz-Dudziak, H. Kawalski}

Lecznica Dzieci i Dorosłych - Szpital im. Ignacego Mościckiego $w$ Chorzowie

Cel pracy: Ocena przydatności tympanometrii szerokopasmowej w diagnostyce schorzeń ucha środkowego u dzieci w zestawieniu z tympanometrią klasyczną.

Material i metody: W okresie od czerwca 2014 roku do końca lutego 2015 roku poddano obserwacji 416 uszu $\mathrm{z}$ różnymi schorzeniami i w różnych stadiach choroby. Wykonano tympanometrię szerokopasmową $\mathrm{z}$ pomiarem absorbancji i częstotliwości rezonansowej oraz klasyczną. Porównano wyniki.

Wyniki: Tympanometria szerokopasmowa pozwala na diagnostykę i monitorowanie zapaleń uszu u dzieci, daje możliwość kontroli stanu ucha środkowego w zmianach zrostowych, perforacjach oraz aktywnym drenażu usznym. Metoda ta pozwala także ocenić wznowę zmian zapalnych, zagrożenie otosklerozą oraz konieczność leczenia chirurgicznego.

Wnioski: Tympanometria szerokopasmowa z możliwością pomiaru częstotliwości rezonansowej oraz absorbancji w znamienny sposób rozszerza możliwości diagnostyczne schorzeń ucha środkowego u dzieci.

Słowa kluczowe: tympanometria szerokopasmowa $\bullet$ absorbancja • częstotliwość rezonansowa • choroby ucha środkowego u dzieci 